\title{
A Dutch Woman in an English World: The Legacy of Alida Livingston of New York
}

\author{
Melinda M. Mohler \\ West Virginia University
}

Follow this and additional works at: https://researchrepository.wvu.edu/etd

\section{Recommended Citation}

Mohler, Melinda M., "A Dutch Woman in an English World: The Legacy of Alida Livingston of New York" (2011). Graduate Theses, Dissertations, and Problem Reports. 4755.

https://researchrepository.wvu.edu/etd/4755

This Dissertation is protected by copyright and/or related rights. It has been brought to you by the The Research Repository @ WVU with permission from the rights-holder(s). You are free to use this Dissertation in any way that is permitted by the copyright and related rights legislation that applies to your use. For other uses you must obtain permission from the rights-holder(s) directly, unless additional rights are indicated by a Creative Commons license in the record and/ or on the work itself. This Dissertation has been accepted for inclusion in WVU Graduate Theses, Dissertations, and Problem Reports collection by an authorized administrator of The Research Repository @ WVU.

For more information, please contact researchrepository@mail.wvu.edu. 
A Dutch Woman in an English World:

The Legacy of Alida Livingston of New York

Melinda M. Mohler

\begin{abstract}
Dissertation submitted to the College of Arts and Sciences at West Virginia University in partial fulfillment of the requirements for the degree of
\end{abstract}
Doctor of Philosophy in History

\author{
Jack Hammersmith, Ph.D., Chair \\ Mary Lou Lustig, Ph.D. \\ Elizabeth Fones-Wolf, Ph.D. \\ Kenneth Fones-World, Ph.D. \\ Martha Pallante, Ph.D. \\ Department of History
}

Morgantown, West Virginia 2011

Keywords: Alida Livingston, Robert Livingston, Livingston Manor, Dutch America

Copyright 2011 Melinda M. Mohler 


\title{
ABSTRACT \\ A Dutch Woman in an English World: The Legacy Of Alida Livingston of New York
}

\author{
Melinda M. Mohler
}

In 1674 , at the conclusion of the Third Dutch War, the Treaty of Westminster placed the Dutch New Netherlands permanently under English control. For the many businesswomen of Dutch heritage who resided in the New Netherlands during the late seventeenth century, this shift in colonial power resulted in a drastic loss of economic freedom and, in many cases, brought an end to their public business ventures. As Dutch businesswomen increasingly retreated from the public sphere, their need to document daily activities dwindled and records of their personal lives all but disappeared. A study of the correspondence of Alida Schuyler Livingston of New York, a member of the Schuyler family by birth and the Van Rensselaer and Livingston families by marriage, illuminates the life of an elite Dutch businesswoman during this transitional phase.

Alida's husband, Robert Livingston, is recognized historically for his political and mercantile ventures. However, it was his wife who managed the couple's vast resources, including 160,000 acres of manorial land, a bakery, brewery, gristmill and sawmill. The Livingstons' agreement to settle - and victual - Palatine refugees at Livingston Manor during the early eighteenth century resulted in disastrous financial consequences for the Livingstons and deplorable conditions for the Palatines. Alida's administration of the manor's industries bolstered the family's finances and permitted them to continue to trade during the worst economic experience of their marriage.

Alida Schuyler Livingston did not own land independently, write a joint will with her spouse or operate a business in her own name. However, her letters reveal that she managed and sold slaves, independently negotiated the price of wheat, supervised millers, bakers and brewers and conducted trade with local Indians during her lengthy marriage - as her husband's equal partner. Viewed through the lens of the twenty-first century, it is tempting to pity Alida's years of hard work that resulted in a business empire attributed to her husband. In reality, Alida Livingston did what her mother and ancestors before her had done labored to provide financial security for her family, but under the constraints of English common law. It is through a study of her daily activities and relationships - with her husband, children, tradesmen, slaves and employees - that the extent of Alida Livingston's contribution to the Livingston family legacy is revealed. 
For Mark 


\section{Acknowledgements}

This project is the result of much guidance, wisdom and encouragement from a number of individuals. I would like to thank Dr. Mary Lou Lustig, my advisor, for her support and direction throughout my entire program of doctoral study. I would also like to thank committee members Dr. Jack Hammersmith, Dr. Kenneth Fones-Wolf, Dr. Elizabeth Fones-Wolf and Dr. Martha Pallante for their insightful suggestions on enhancing and strengthening my investigation of the life of Alida Livingston. In addition, I would like to offer special thanks to Dr. Martin Berger, Dr. Lowell Satre, Dr. Martha Pallante, Dr. Les Domonkos and Dr. Saul Friedman of Youngstown State University for their direction and encouragement as I began my graduate studies.

The Dean's office of the Eberly College of Arts and Sciences at West Virginia University, and the Department of History, provided generous funding for my research. Librarian Peter Thayer of Marietta College provided special assistance in the procurement of hard-to-find articles and other information. My colleagues at Marietta College, in particular Dr. Mike Tager, Dr. Matt Young, Dr. Katy McDonald and Dr. Jim O'Donnell, provided numerous opportunities for personal and professional growth.

The Gilder-Lehrman Institute of American History and the Colonial Dames of America provided substantial financial assistance toward the completion of this project. I would also like to offer special thanks to the archivists at the Roosevelt Library in Hyde Park, New York, for their patience and support. 
Many friends and family members contributed not only to the completion of this project but also to the years of schooling upon which it rests. First and foremost, I thank my Lord and Savior for the abilities, and opportunities, He has given me. My parents, Clyde and Nellie Hicks, deserve far greater thanks than can possibly be offered in a few lines. They worked long hours and sacrificed a number of material things throughout the years to pay for my schooling. I hope to someday become the teacher my mother was. Thanks to my sister, Stephanie, for being "super sis" during some very trying times. Special thanks to James DePalma, Chuck Keeney, Katharine Antolini, Mark Myers, Eugene Van Sickle and Cathy Rodabaugh for the support and friendship that made graduate school one of the most enjoyable and memorable experiences of my life.

Finally, I would like to thank my husband, Mark. It is difficult to marry someone who is in the middle of the dissertation process, but your love, support and encouragement never wavered. We did it! 


\section{TABLE OF CONTENTS}

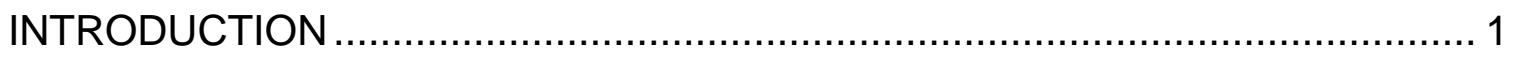

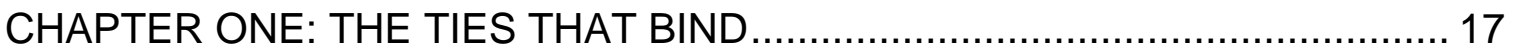

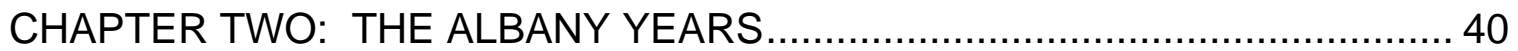

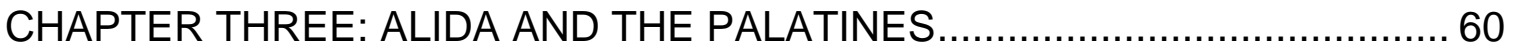

CHAPTER FOUR: THE MANOR YEARS: SURVIVAL $\ldots \ldots \ldots \ldots \ldots \ldots \ldots \ldots \ldots \ldots . . \ldots \ldots$

CHAPTER FIVE: MARRIAGE AND THE MATRIARCH $\ldots \ldots \ldots \ldots \ldots \ldots \ldots \ldots \ldots . \ldots 9$

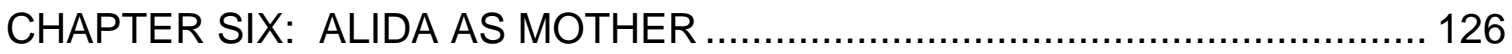

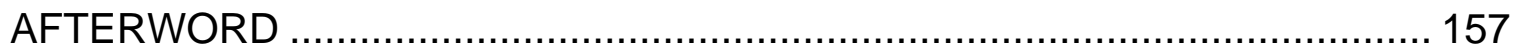

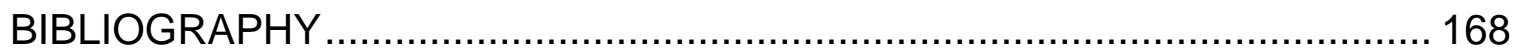




\section{INTRODUCTION}

In March of 1664, King Charles II of England granted to his brother James, the Duke of York, an extensive portion of land in the New World that included the Dutch colony referred to as the New Netherlands. The Dutch trading power served as a persistent threat to the English, who certainly did not want their rival prospering in the New World. The colony, which consisted of a conglomeration of settlers who "communicated in 18 languages," did not have the social cohesion or military support to defend itself against a British assumption of power. ${ }^{1}$ In a bloodless confrontation, the New Netherlands became New York and in 1674, the Treaty of Westminster ended the Third Dutch War, placing the New Netherlands permanently under British control.

If the British had expected the newly conquered Dutch to transition rapidly to English customs, however, they were to be sorely disappointed. The clannishness of Dutch communities and their powerful trade networks suppressed the assumption of English ways in parts of New York for generations. The exception to this rule was the prompt reduction of legal freedoms for Dutch women under English law. Dutch women, once known for their management skills and business savvy, quickly became femme coverts. Though Dutch

${ }^{1}$ For Dutch violation of the English Navigation Acts, see Russell Shorto The Island at the Center of the World (New York: Vintage Books, 2005), 294-300; Michael Kammen, Colonial New York: A History (New York: KTO, 1978), 56-57 and 71-72; George Louis Beer, British Colonial Policy 1754-1765 (Gloucester: Peter Smith, 1958), 116-117. The colony briefly fell back under British control and was again established under the British in 1674. 
women could no longer legally conduct commerce in their own names, they still possessed extraordinary business aptitude that served their families well for generations.

Alida Schuyler Livingston did not own land independently, write a joint will with her spouse or operate a business in her own name. However, her letters reveal that she managed and sold slaves, independently negotiated the price of wheat, supervised millers, bakers and brewers and conducted trade with local Indians during her forty-eight years of marriage - as her husband's equal partner. Viewed through the lens of the twenty-first century, it is tempting to pity Alida's years of hard work that resulted in a business empire attributed to her husband. In reality, Alida Livingston did what her mother and ancestors before her had done - labored to provide financial security for her family, but under the constraints of English common law. It is through a study of her daily activities and relationships - with her husband, children, tradesmen, slaves and employees that the extent of Alida Livingston's contribution to the Livingston family legacy is revealed.

On December 8, 1941, New York resident Katherine Osborn donated two file cabinets of historical documents to the Franklin D. Roosevelt Library at Hyde Park, New York. The cabinets contained an extensive collection of privately owned colonial documents. The collection, now referred to as the Livingston Family Papers, includes hundreds of documents pertaining to life in early New York. Osborn, an acquaintance of the president, had previously declined to donate the files but commented that in the wake of the bombing of 
Pearl Harbor it seemed to be a good time "to be looking after the Arts of Peace." The 8,000 documents provided by Osborn offer an unparalleled look into the many members of the Livingston family in New York. More than half a century later, the Gilder-Lehrman Institute of American History in New York City obtained the documents and began the lengthy task of cataloging them. Though the collection contains thousands of documents - varying from letters to wills and receipts - in the words of translator Adrian van der Linde, “. . . the private correspondence between Robert and Alida [Livingston] is . . .the jewel in the crown. $^{2}$

The correspondence which makes up this "jewel in the crown" of the Livingston family papers has become the topic of much historical interest during the past two decades. As the necessity for documentation of Dutch businesswomen's daily economic activities dwindled, traces of their personal lives all but disappeared from history. In the wake of this transition it is their personal correspondence which best illuminates the private lives and relationships of elite Dutch women after 1674. In an article titled, Business Letters of Alida Schuyler Livingston, 1680-1726, Linda Briggs Biemer published translations of twenty-nine of Alida's letters to second husband Robert Livingston. Almost every historian who addresses the topic of businesswomen in

${ }^{2}$ A. Jos van der Linde, The Livingston-Redmond Papers: Abundant Source for Family History, 7. Presented at: New Netherland at the Millennium: The State of New World Dutch Studies in New York City, October 19-21, 2001. Jos van der Linde's translations were still on file at the Franklin D. Roosevelt Library in Hyde Park, New York, in 2006. The original documents are on file at the Gilder-Lehrman Institute of American History in New York City. Unless noted otherwise, all translations in this dissertation are Jos van der Linde's. The Gilder-Lehrman Institute obtained the collection in 1993. 
New York mentions these translations, as for years they provided the only tangible evidence of Alida's economic ventures. ${ }^{3}$ Mrs. Livingston's voluminous and detailed correspondence, rendered difficult even after translation due to her phonetic spelling and complete lack of punctuation (not one mark in the entire collection) inhibits most researchers from investigating her letters in their entirety. During the 1980s, A. P.G. Jos van der Linde completed a translation of the letters between Robert and Alida Livingston during his tenure as a Fulbright scholar. Though lapses in the couple's correspondence prohibit an extensive chronological study, these translations provide an unparalleled perspective of Alida Livingston's relationship with her husband, children and grandchildren and insight into the everyday frustrations she experienced as a working mother and businesswoman in colonial New York. ${ }^{4}$

Any study of the Livingston family also demands an understanding of those among whom they lived and socialized. The Ecclesiastical Records of New York, the Annals of Albany and The Winthrop Papers all provided necessary context for certain aspects of this study. The extensive collections of The Documentary History of New York and Documents Relative to the History of New

${ }^{3}$ Linda Briggs Biemer, "Business Letters of Alida Schuyler Livingston, 16801726" New York History, 63:2 (1982), 182-207. Biemer's work is standard for all historians of family or women's history in New York and is a wonderful resource. In order to complete a thorough study of Alida Livingston, however, the entire collection must be utilized.

4 Because the Livingston letters cover only Robert's absences from Albany or the Manor, conducting a chronological study of Alida Livingston is nearly impossible. A. Jos Van der Linde completed the study for his dissertation at Leiden. 
York were particularly valuable and provided legal documentation for many of the events discussed throughout the dissertation.

Despite growing interest in the history of the Dutch in the New Netherlands and colonial New York, histories of Dutch women and their relationships are scarce. Notwithstanding the efforts of the New Netherland Project to make seventeenth century documents more accessible to historians via new and updated translations, studies of Dutch New York are still infrequent. According to New York historian Firth Fabend, "Even if we expand the definition of New Netherland to include, for the purposes of study, the Dutch experience in North America up to the time of the American Revolution, the pickings are slim." Her own work, A Dutch Family in the Middle Colonies, 1660-1800, sets the standard for studies of Dutch family relationships through the exploration of the Harings, a farming class family in New York and New Jersey. Along with Jane Zimmerman's The Women of the House, a detailed study of the life of Dutch shipping magnate Margaret Hardenbroeck Philipse, Fabend's study virtually completes the current list of texts available on specific Dutch families. While researchers have made excellent strides in the study of Dutch customs, architecture and home life in New York, they have revealed little about the

${ }^{5}$ Firth Fabend, Sex and the City: Relations Between Men and Women in New Netherland, 2. Presented at: New Netherland at the Millennium: The State of New World Dutch Studies in New York City, October 19-21, 2001; Firth Fabend, A Dutch Family in the Middle Colonies, 1660-1800 (New Brunswick: Rutgers University Press, 1991); Jean Zimmerman, The Women of the House: How a Colonial She-Merchant Built a Mansion, A Fortune, and a Dynasty (New York: Houghton Mifflin Harcourt, 2006). 
interaction between Dutch businesswomen and their husbands, children and employees. ${ }^{6}$

There are several reasons for the absence of Dutch family histories in the study of New York. Prior to the takeover of the New Netherlands by the English, most Dutch settlers came to America as single men and left behind few personal details of their lives. The multiplicity of languages and cultures in early New York has further complicated the study of the New Netherlands. In The Empire State: A History of New York, Milton M. Klein argues that British attempts to anglicize the Dutch resulted in increased efforts by the Dutch to maintain their customs, language and way of life. ${ }^{7}$ In areas such as Albany, where Alida Livingston resided for much of her life, citizens spoke Dutch almost exclusively until the mideighteenth century. However, Albany did not consist of only Dutch inhabitants. Throughout the eighteenth century, Dutch citizens came into contact with other cultures through trade and Dutch women increasingly married into English families. As a result, it is difficult to determine the experience of the Dutch in early New York. Were these blended families predominantly Dutch or English? Did a

${ }^{6}$ Several excellent studies of Dutch customs and home life have been published in recent years, including Benjamin Roberts' Through the Keyhole: Dutch childrearing Practices in the $17^{\text {th }}$ and $18^{\text {th }}$ Century: Three Urban Elite Families (Netherlands :Verloren, 1998). Some of the most comprehensive studies of Dutch traditions come from older texts, such as Esther Singleton's Dutch New York (New York: Dodd, Mead and Company, 1909) and Alice Morse Earle's Home Life in Colonial Days (New York: The Macmillan Company, 1898) and Child Life in Colonial Days (New York: The Macmillan Company, 1899). Earle's discussions of home and child life reference all of colonial America but include significant detail about Dutch customs - an anomaly for a writer of the late nineteenth century.

7 Milton M. Klein, ed., The Empire State: A History of New York (Ithaca: Cornell University Press, 2001), 105. 
Dutch woman abandon her heritage upon marrying an Englishman? In Before The Melting Pot: Society and Culture in Colonial New York City, 1664-1730, Joyce D. Goodfriend discusses the "ethnicization" of New York City and specifically addresses the need for cultural intermarriage in the late seventeenth century and early eighteenth centuries. Male immigrants to the colony, particularly Englishmen, realized economic reward by marrying into prominent Dutch families. This blending of cultures has made it difficult to assess which attributes are Dutch specific. ${ }^{8}$

Though colonial gender histories occasionally mention Dutch women and even Alida Livingston in particular, most focus almost solely on either the loss of legal rights experienced by Dutch women after the Third Dutch War or the distinctiveness of their rights prior to that time. While studies of English women most often place them at hearth and home, the unusual freedoms of Dutch women during this period has resulted in their historical representation as aggressive businesswomen whose skills dwindled quickly into the background under English imperatives. In his history of the American colonies, Alan Taylor defines the Dutch woman's experience in English New York:

The imposition of English common law eroded the opportunities for Dutch colonial women to hold, manage and dispose of property... Dutch women dwindled as entrepreneurs, litigants and testators. During the early 1660 s about forty-six women conducted commerce in their own names at Beverwyck; none did so in the Albany of $1700 .^{9}$

8 Joyce Goodfriend, Before the Melting Pot: Society and Culture in Colonial New York City, 1664-1730 (Princeton: Princeton University Press, 1992), 219-220.

9 Carol Berkin, First Generations: Women in Colonial America (New York: Hill \& Wang, 1996), 87; Alan Taylor and Eric Foner, American Colonies: The Settling of North America (New York: Penguin Group Inc., 2001), 260; Deborah A. Rosen, "Women and Property across Colonial America: A Comparison of Legal Systems in New Mexico and 
Linda Briggs Biemer's Women and Property in Colonial New York: The Transition from Dutch to English law 1643-1727 has become one of the most important resources on the lives of Dutch "transitional" women in New York after 1664. However, her biographical depiction of elite women, including Alida Livingston, is limited to their roles as businesswomen in early New York versus their status under Dutch rule. In Courts and Commerce: Gender, Law, and the Market Economy in Colonial New York, Deborah A. Rosen also uses eighteenth century documents to discuss the legal restraints placed on women by the law. Rosen's article titled, Women and Property across Colonial America: A Comparison of Legal Systems in New Mexico and New York, and Joan R. Gundersen and Gwen Victor Gampel's article, Married Women's Legal Status in Eighteenth-Century New York and Virginia, give context to the legal experience of women in New York during the colonial period. Because Dutch women prior to 1664 could own businesses independently, inherit property equally and enter into a marriage as femme soles, records of women in the court system abound. It is their private lives that have remained shrouded in secrecy. ${ }^{10}$

The historical fascination with Dutch businesswomen during the colonization and transitional phase has long overshadowed the reality that most

New York," The William and Mary Quarterly 60.2 (2003), 377. Albany was first known as Beverwyck.

${ }^{10}$ Linda Briggs Biemer, Women and Property in Colonial New York: The Transition from Dutch to English law 1643-1727 (Ann Arbor: UMI Research Press, 1983); Gundersen, Joan R., and Gwen Victor Gampel. "Married Women's Legal Status in Eighteenth-Century New York and Virginia." The William and Mary Quarterly, 39.1 (1982): 114-34; Rosen, "Women and Property," 355-381. 
female entrepreneurs were also wives and mothers. Regardless of a Dutch woman's proficiency as a merchant or trader, her first responsibility was to her husband and children. Dutch society, both in the Netherlands and America, frowned upon women who did not responsibly fulfill the role of mother. This responsibility dictated that Dutch women limit their writing to business matters rather than the journals kept by many of their English contemporaries. Unfortunately, though Dutch women were generally better educated than their English peers, they left behind few records of their personal lives. As a result, studies on Dutch women as wives and mothers are scarce and usually appear as chapters in broader studies of the Dutch experience in America. For example, Martha Shattuck's compilation of essays, Explorers, Fortunes and Love Letters: A Window on New Netherland includes a chapter by Adriana E. van Zwieten titled, "Glimpses of Childhood in the Colony of New Netherland." Arthur Wallace Calhoun provides an engaging glimpse of Dutch families in early New York in his broad social analysis of the American family, but again, the Dutch experience is limited to two chapters dealing with sex, marriage and family life. ${ }^{11}$ Rarer still are studies of Dutch wives and mothers during the transition from Dutch to English authority. While investigations of legal changes during this period abound, the lives of women and children have faded into obscurity. As a result, greater attention is now being given to available Dutch family manuscripts in hopes of broadening historical representation of Dutch marriages and family life.

${ }^{11}$ Martha Dickinson Shattuck, ed., Explorers, Fortunes and Love Letters: A Window on New Netherland (Albany: New Netherland Institute, 2009); Arthur Wallace Calhoun, A Social History of the American Family from Colonial Times to the Present, Volume I (Cleveland: The Arthur H. Clark Company, 1917). 
Several notable studies of the Livingston family provide the necessary context for a detailed study of Alida Livingston. Most importantly, Lawrence Leder's Robert Livingston, 1654-1728, and the Politics of Colonial New York , Cynthia Kierner's Traders and Gentlefolk: The Livingstons of New York, 16751790, and Clare Brandt's An American Aristocracy: The Livingstons. Leder's research on the first Lord of the Manor provides a context for studying his relationship with Alida and is particularly helpful as a reference point for issues that are briefly mentioned in her letters but lack detail. Kierner's multigenerational study of the Livingstons is thorough and traces the elite family's trials and successes as they attempted to establish a financial dynasty. Clare Brandt provides the most comprehensive view of Alida Livingston, using the couple's letters to paint a more comprehensive picture of Alida's personality, though again, her inclusion in the text is minimal as she appears as only one of hundreds of Livingstons researched for the study. ${ }^{12}$

The chapters that follow portray the life of Alida Schuyler Livingston as evidenced in the Livingston correspondence. While several facets of Alida Livingston's life have previously garnered the interest of historians, particularly

${ }^{12}$ Lawrence H. Leder, Robert Livingston, 1654-1728: and the Politics of Colonial New York (Charlotte: Published for the Institute of Early American History and Culture at Williamsburg, Va., by the University of North Carolina Press, 1961); Cynthia Kierner, Traders and Gentlefolk: the Livingstons of New York, 1675-1790 (Ithaca: Cornell University Press, 1992); Clare Brandt, An American Aristocracy: The Livingstons (Garden City: Doubleday \& Company, Inc. 1986). Brandt's history in the dramatic arts is evident in her study of the Livingstons, which comes alive with her very dry sense of humor. 
her managerial skills and the Palatine affair, historians have not studied her life using a thematic approach. Using this method, I have concentrated on major events in her life from multiple perspectives, finally filling some of the many historical gaps in the study of the Livingston family.

I begin with an investigation of Alida Schuyler Livingston's family and their social significance in Albany. Slaveholding, leadership in the Dutch Reformed Church and a strong trade network with local Native Americans determined the social status necessary for citizens to accumulate credit in Albany. Due to frequent shortages of specie, New York traders often relied on promissory notes and bonds in the absence of hard cash and businessmen relied heavily upon extensive trade networks and the generous extensions of credit guaranteed by rank. In the words of Simon David Middleton, "In an economy starved of specie... credit was the lifeblood of local trade." A small number of privileged Dutch families dominated small towns like Albany for generations and their marriages established a widespread system of credit unavailable to newcomers or members of the lower class. Chapter one investigates these elite kinship networks and Alida Livingston's attempts to duplicate her family's wealth for future generations by employing the strategies learned from her family during her early years. ${ }^{13}$

${ }^{13}$ Simon David Middleton, From Privileges to Rights: Work and Politics in Colonial New York City (Philadelphia: University of Pennsylvania Press, 2006) 102-107. Colonists tended to import more than they exported during the late seventeenth and early eighteenth centuries, which is partially responsible for the lack of specie. 
Chapter two explores the evolution of Alida and Robert Livingston's business relationship during the first years of their marriage. Arthur W. Calhoun claims, "It was in the home and in business that [a Dutch] woman shone rather than in intellectual affairs." ${ }^{14}$ Though the Dutch considered elementary education for girls to be commonplace, their schooling traditionally served as preparation for business management rather than academic endeavors. However, because Dutch women could no longer operate businesses in their own names during Alida's lifetime, historians have frequently relegated them to the position of Laurel Thatcher Ulrich's "deputy husbands." Perhaps a better description might be "assistants," as English women who fell under the umbrella of Ulrich's description managed business affairs in their husbands' absences but rarely made independent business decisions as an equal partner. Chapter two illuminates the level of equality inherent in the Livingston's relationship and its importance during the early years of their marriage.

Chapter three reveals the extent of Alida's contributions to the Livingston family during the Palatine affair. The family's move to the extensive property of Livingston Manor in 1699, coupled with Robert Livingston's increasing political duties and a disastrous decision to participate in Britain's Palatine naval stores program, resulted in a very real threat to the family's financial survival. Robert's dependence on his wife's managerial skills increased dramatically during these years. Robert and Alida's involvement in the colony's Palatine immigration program has been a primary topic of discussion in histories of the Livingstons.

${ }^{14}$ Calhoun, A Social History, 169. 
The couple's often poor response to their victualing duties has earned the ire of historians, yet the personal devastation to the Livingstons' livelihood as a result of Britain's refusal to pay for the Livingstons' services requires further investigation. Chapter three will address both the financial and personal ramifications of the Palatine affair to Alida's daily work load and the couple's bank account.

In chapter four, I investigate Alida Livingston's efforts to rebuild her family's finances after the Palatine affair. The manor's many industries, which included a bakery, brewery and general store, became the basis of the family's economic survival both during and after the Palatine program. The credit that the Livingstons had worked so hard to develop was seriously threatened during these years. In order for the family to pay their debts, Alida expanded the manor's output and assumed a staggering daily workload. The flour and beer produced under her direction permitted the couple to maintain credit and connections that solidified their fortune for future generations.

Chapter five explores a very private aspect of Alida Livingston's life - her first marriage to Nicholas Van Rensselaer, and, upon his death, her lifelong union with Robert Livingston. In an era where death frequently took young lives, subsequent nuptials were common. The marriage of a very young and prominent Dutch widow to a middling Scotsman was not. Unlike their English counterparts, Dutch women married almost exclusively within their own ethnic communities and rarely displayed the affection apparent in the marriages of their 
English peers. In A Citizen of the World, Oliver Goldsmith aptly describes the difference between English and Dutch marriages:

The English love their wives with much passion; the Hollanders with much prudence. The English, when they give their hands, frequently give their hearts; the the Dutch give the hand, but keep the heart wisely in their own possession. . The English expend many of the matrimonial comforts in the first year; the Dutch frugally husband out their pleasures, and are always constant, because they are always indifferent." ${ }^{15}$

The Livingston marriage both confirms and contradicts Smith's declaration, as well as contemporary ideas regarding the maintenance of Dutch customs in Dutch-English households. Beginning with Alida's marriage to the "unorthodox dominie", Nicholas Van Rensselaer, this chapter reveals the influence of Alida's first marriage on her life with Robert Livingston and illuminates the Livingstons evolution from business partners to deeply devoted spouses.

Evidence of Alida Livingston's capacity for affection is also evident in her relationship with her six surviving children. Though several studies have duly recorded the Livingston children's successes - and failures - they have discussed little of their relationship with the Livingston matriarch. This is common, as Alice Morse Earle notes, "We have ... scant sources from which to

${ }^{15}$ Oliver Goldsmith, The Citizen of the World: Or, Letters from a Chinese Philosopher, Residing in London, to his Friends in the East, Volume The First (London: Printed for Wm Otridge and Son, John Walker, James Scatchard, Vernor \& Hood, D. Ogilvy and Son, and Darton \& Harvey, 1800), 69-70. 
learn of the life of children in colonial New York." ${ }^{16}$ Though Dutch families doted on their children, the necessities of daily life during the seventeenth and eighteenth centuries demanded that parents focus the majority of their attention on economic and physical survival. As a result, even elite families like the Livingstons and Van Rensselaers left little record of parent-child relationships. The illiteracy of lower class families further prohibits extensive discussion of childhood in Dutch New York, with the exception of court and orphanmasters records. In chapter six, I will examine Robert and Alida Livingston's relationship as parents as well as Alida's influence on the Livingston children through a study of their letters to each other and to their children. Alida Livingston's ability to write provides a distinctive window through which to view her life as a colonial parent. It is these brief glimpses of Alida as mother than perhaps best balance the often cold and calculating deportment for which she is best known.

My research builds upon the work of Brandt, Kierner and the collective work of historians of New York women and families during the seventeenth and eighteenth centuries. The study of Alida Livingston's relationships fills a gap in the history of Dutch businesswomen and their families in early New York and illuminates her personal and economic contributions to her family's success. The thematic approach necessitated by gaps in the Livingstons' correspondence is in many ways a blessing. While a thorough chronological study of Alida's life would certainly be profitable, the thematic approach I have employed provides a

${ }^{16}$ Alice Morse Earle, Colonial Days in Old New York (New York: Charles Scribner's Sons, 1896), 17. Earle reveals that children in colonial Albany had more freedoms to play openly that did children of Dutch, Swedish or German settlers. 
glimpse of previously unknown aspects of the Livingstons' lives that make them more approachable. I have attempted to reveal Alida Livingston's life as accurately as possible, rendering judgments only when sufficient source material allowed me to do so.

The family's financial problems, Albany's political dramas and the ruinous Palatine experiment all take on a new light when viewed through the lens of the Livingstons' private letters. My investigation of Alida's correspondence reveals several distinctive aspects of her life not apparent in other studies, including her marital relationship with Robert Livingston, her personal interactions with the Livingston children and their mates and the unusual physical and economic burdens that she bore with equanimity during her forty-eight years of marriage. Studies of the Livingston family have dominated New York history for generations. It is my hope that this study will allow Alida Livingston to assume her rightful place beside the men whose lives and careers were established as a result of her hard work and sacrifice. 


\section{CHAPTER ONE:}

\section{THE TIES THAT BIND}

Alida Schuyler Livingston began - and ended - her life as a member of one of Albany, New York's most influential families. Born into the prominent Schuyler clan, she married the wealthy Nicholas Van Rensselaer at age nineteen and, after his death in 1678, married his secretary, the young Robert Livingston. During her lengthy union with Livingston, Alida strove to replicate the only lifestyle she had ever known, employing strategies - such as slave labor and strong Indian relations - that she had learned as a part of Albany's most elite social circle. By her death in 1726, she had successfully laid the foundation for a new generation of Livingstons to assume their role as members of one of New York's most influential families.

Alida entered the world as the daughter of one of Albany, New York's most prominent citizens. In 1656 her father recorded her birth in the family Bible, the primary center for family history in Dutch homes: "the 28 february being Monday is born our second daughter Alyda van Schuyler May the Lord god let her grow up in virtues to her salvation Amen."1 Her father, Philip Pieterse Schuyler, emigrated from Holland and married his wife, Margarita Van

${ }^{1}$ George Washington Schuyler, Colonial New York: Philip Schuyler and His Family, Volume I (New York: Charles Scribner's Sons, 1885), 183. Though the Schuyler family Bible initially listed her name as "Alyda," it was not uncommon for Dutch citizens to modify their names after the English assumption of power. Alida's father frequently changed the spelling of his name during his lifetime, dropping "van" from his children's names in 1666. For more information on the Schuyler's naming habits, see Marion Harland's "An Old New Jersey Homestead," in The Home Maker: An Illustrated Monthly Magazine Volume II: April to September 1889. (New York: The Home Maker Company, 1889), 104. 
Slichtenhorst, on December 12, 1650, at Beverwyck, New Netherland. Little is known of Philip Schuyler prior to his marriage, as fire consumed the family papers in $1763 .^{2}$ However, the details of his time in colonial Albany more than atone for the scarcity of information regarding his earlier life. His choice of a bride, the only daughter of Brent Arentse Van Slichtenhorst, resident-director of the patroonship of Rensselaerswyck in Albany, offered connections that certainly benefitted the young newcomer. Rensselaerswyck's vast territory, twenty-four miles long and forty-eight miles wide, served as a feudal-style manor and dominated Albany society from the seventeenth through the early nineteenth centuries. ${ }^{3}$ Within five years of his arrival at Beverwyck, Philip Schuyler's fortune dramatically increased, no doubt owing to hard work and abundant family connections. Schuyler had also learned that successful trade, at least in Albany, depended upon positive relations with local Native American tribes. Schuyler's interaction with Mohawks is recorded as early as November of 1655 and continued throughout his lifetime. The Schuylers frequently welcomed Mohawk sachems, or chiefs, to their home, and "their dusky forms were stretched almost nightly" in the family's barn and backyard. While many citizens scorned the idea

\footnotetext{
${ }^{2}$ Beverwyck, New York, eventually became known as Fort Orange and later, Albany.

${ }^{3}$ E.B. O'Callaghan, ed., The Documentary History of the State of New York III (Albany: Weed, Parson \& Co. Public Printers, 1850), 916 (map) Rensselaerswyck was granted to the first patron, Kiliaen Van Renssealer, under Dutch administration and later gained English manorial rights in a patent from Governor Thomas Dongan to the Van Rensselaer family in 1685. A detailed history of claims on the patroonship/manor from its inception through the mid-nineteenth century is found in Documents of the Assembly of the State of New-York, Sixty-Seventh Session, 1844, Volume VII (Albany: Carroll and Cook, Printers to the Assembly, 1844). In 1685 the manor's holdings included approximately one million acres.
} 
of welcoming "savages" onto their property, the arrangement provided the Schuylers with a dominant position in local trade as well as much needed protection. Native Americans never attacked the Schuylers or their property during Philip's lifetime. ${ }^{4}$

In colonial America, property holdings signified prosperity, both for current and future generations. Among the early Schuyler family holdings were a home in Albany, two homes/lots in New Amsterdam, and "a store-building and dwelling ... on a street near the East River." In Albany, Schuyler eventually "owned houses in Albany, on Broadway, State Street, Beaver Street, and North Pearl Street" as well as the family home named "de Vlachte," or in English, "The Flatts." Schuyler purchased The Flatts from Jeremias Van Rensselar, director of Rensselaerswyck, in 1672 for 8,000 guilders. The estate included an island, a farm called "Winter's Plantation" and a "bouwery." The Flatts became the Schuylers' primary residence and served as their ancestral home for generations. The farm's location made it one of the most coveted pieces of property in Albany. Indians commonly passed the property on their way to trade furs at Fort Orange,

${ }^{4}$ Bayard Tuckerman, Life of General Philip Schuyler, 1733-1804 (New York: Dodd, Mead and Company, 1903), 21; Harold Donaldson Eberlein and Cortlandt Van Dyke Hubbard, Historic Houses of the Hudson Valley (New York: Architectural Book Publishing Company, 1942), 133. Philip Schuyler purchased a number of properties during his lifetime and did not limit his purchases to Albany. His holdings included properties in areas such as New York City, Albany, Esopus, and "a tract on the Mohawk River." The Schuylers home became one of the area's most important venues for Indian relations. Alida's brother, Pieter, who became mayor of Albany, continued his father's positive relationship with local Native Americans.

${ }^{5}$ Charlotte Wilcoxen, Dutch Trade and Ceramics in America in the Seventeenth Century (New York: Albany Institute of History and Art, 1987), 88; Schuyler, Colonial New York, 156-157. 
providing the Schuylers with an excellent opportunity to dominate local Indian trade. The most desirable property in town was not always the largest or grandest lot, but the lot closest to the city gates. The original home, built in the 1640s, is described as, " 28 feet wide and 120 long - 40 feet for dwelling and 80 for the quarters for farm laborers, cattle and horses." ${ }^{6}$ By the mid-eighteenth century, upgrades to The Flatts made it a place of both beauty and location. Anne Grant, author of Memoirs of an American Lady, personally visited the Flatts during the 1760 s and described it as "a fertile and beautiful plain on the banks of the river," possessing such beauty that "it is not in my power to describe it." $A$ river flanked the mansion on one side and an abundance of hills and a waterfall on the other side. Relative George Washington Schuyler later described the mansion as,

A large brick house of two or rather three stories... The lower floor had two spacious rooms... on the first there were three rooms, and in the upper one four... a large portico at the door...At the back of the large house was a smaller and lower one...One roome...in the greater house only, was opened for the reception of company. ${ }^{7}$

${ }^{6}$ Roderic H. Blackburn and Ruth Piwonka, eds., Remembrance of Patria: Dutch Arts and Culture in Colonial America, 1609-1776 (Albany: Albany Institute of History and Art, 1988), 91-92.

${ }^{7}$ Schuyler, Colonial New York, fn pg. 156. Schuyler uses Mrs. Anne Grant's description of The Flatts in addition to his own. 
Unlike their English counterparts, very few Dutch families dwelled in traditional log homes, preferring instead to alternate two walls of timber with two walls of brick. In Albany, the brick walls faced the street, adding a unifying touch to the city's façade. ${ }^{8}$ However, few families possessed the cash resources necessary to maintain a residence in the style of the Schuylers. Mrs. Anne Grant describes in her memoirs other properties owned by the Schuylers. "In full view of the mansion at the Flats, were two large and well-built dwellings, inhabited by Colonel Schuyler's two younger sons, Peter and Jeremiah." The family's eldest son, Philip, owned a home in Albany and inherited "the costly furniture of the family, of which paintings, plate and china constituted the valuable part ..." ${ }^{\prime 9}$ The Schuylers' wealth also permitted them to grant homes as wedding gifts to both daughter Gertrude and son Brant. When Philip Schuyler died on May 9, 1683, he left behind a vast estate which formed the basis of the family's wealth for generations.

For the Dutch in Albany, prosperity depended upon kinship networks such as those formed by the Schuylers, Van Rensselaers and Livingstons. Businessmen often extended credit on the virtue of a good name, and, in an often cash poor economy, credit was essential for survival. Historian David G. Hackett notes that Albany's population more than doubled between 1697 and

\footnotetext{
${ }^{8}$ William Elliott Griffis, The Story of New Netherland: The Dutch in America (Boston: Houghton Mifflin Company, 1909), 162.

${ }^{9}$ Anne MacVicar Grant, Memoirs of an American Lady, with Sketches of Manners and Scenery in America, As They Existed Previous to the Revolution (New York: George Dearborn, 1836), 147-148. "Mrs. Grant," as she is most often referred to, was a guest of Margarita Schuyler, Alida Livingston's niece, during the 1760s. She describes the home during later years, though she toured the original structure.
} 
1757 due to "the multiplication of Dutch families" through childbirth. Most Dutch women in Albany gave birth to eight children during their childbearing years. ${ }^{10}$ In upper class homes, these children traditionally married into other prosperous Albany families, forming financial networks that were nearly impossible for newcomers to the city to sever. The Schuylers serve as a perfect example of the importance of these ties. Philip Schuyler and Margarita Slichtenhorst's eight children resided in Albany and married into prosperous merchant families, maintaining nine separate residences within the city by the early eighteenth century. Alida married Nicholas Van Renssealer of Rensselaerswyck and Robert Livingston. Her eldest sister, Geertruy Schuyler, married Stephanus Van Cortlandt of Rensselaerswyck. Brother Peter Schuyler married Engeltie Van Schaick, daughter of a wealthy Albany resident. Their daughter, Margarita, married Robert Livingston, Jr., and daughter, Elizabeth, married Alexander Hamilton. ${ }^{11}$ The fortunes of the Schuyler, Livingston, Van Renssealer and Cortlandt families depended on these marriages, permitting them to dominate Albany's political and civic affairs for many years.

Kinship ties also extended to the practice of religion in Albany. The Dutch Reformed Church, which stood like a sentinel over the town's intersecting main streets, served both secular and religious purposes. Almost every Dutch citizen boasted membership in the local church, and inside its walls community status

${ }^{10}$ David G. Hackett, The Rude Hand of Innovation: Religion and Social Order in Albany, New York, 1652-1836 (New York: Oxford University Press, 1991), 15.

11 Cuyler Reynolds, ed., Hudson-Mohawk Geneaological and Family Memoirs Volume I (New York: Lewis Historical Publishing Company, 1911), pp. 29-30. Reynolds provides a detailed account of the Schuyler family tree. Each of the Schuyler children married well and inherited property equally upon their mother's death in 1711. 
and privilege were displayed as ostentatiously as they were in the streets of the city. When the first Dutch church was built in Fort Orange in 1656, several of the city's wealthiest citizens paid for the privilege of displaying their family's coat of arms on the church windows, among them the Schuylers. Church seats were "purchased and assigned" by the wealthiest members of the community in order to hand them down to future generations. A good seat in the Dutch Reformed Church helped many a young man gain respectability in the community. The Schuylers, of course, laid claim to the first and most prominent bench. In 1719 the church laid out specific rules for the inheritance of church seats:

... whenever any of these seats is vacated by death, it shall descend to the eldest son of the last occupant living in the county; and in default of sons, to a son-in-law; and in default of sons-in-law, to an own brother; always descending successively to own sons, or if there be no sons or they shall be absent then to sons-in-law; then to own brothers; the first occupant paying thirty shillings for his seat, and his successor fifteen shillings..."

Once a male church member purchased a seat, it was virtually impossible for that seat to pass outside of his family. Therefore, newcomers to Albany had little hope of breaking into the church's inner circle. The status that allowed families such as the Schuylers and Van Rensselaers to control Albany's politics also allowed them to direct the community's religious and social center. Like their husbands, elite women also paraded their status within the church walls. Records from a meeting of the consistory, March 20,1719, state, "on the death or removal of the occupant of a seat, such seat should fall to her next of kin upon the payment of two pieces of eight and the customary contribution to the 
minister's salary . .."12 Wealthy men dominated the Dutch Reformed Church, but women also played an integral role in the social function - and hierarchy - of the church. ${ }^{13}$

When Alida married the controversial Albany minister Nicholas Van Rensselaer in 1675 , she became a member of another of the colony's most influential families. The Van Rensselaers, like the Schuylers, dominated Albany's trade, as well as the Dutch Reformed Church where Nicholas served briefly as Dominie. The Van Rensselaer's home, despite its ownership by prominent citizens, did not differ greatly from its neighbors, at least during the early years of Albany. In 1666, a flood destroyed the Van Rensselaer home near "Patroon's Creek" and forced the building of a new home, "straight and plain, of two rooms, but the cellar built of stone and further with a stone foundation." Most members of Albany's upper class built homes for size and function rather than style, with lower floors serving as stores or trade venues. As the town became more prosperous, all houses in the city were required to be "two rooms deep and

\footnotetext{
12 Hackett, Rude Hand of Innovation, 19-20; "Meeting of the Consistory," in Joel Munsell, ed., Collections on the History of Albany, from its Discovery to the Present Time, with Notices of its Public Institutions and Biographical Sketches of Citizens Deceased, Volume I (Albany: J. Munsell, 1865), 61.

${ }^{13}$ Renee S. House and John W. Coakley, eds., offers a compelling look into the lives of Dutch women and their religion in Patterns and Portraits: Women in the History of the Reformed Church in America (Grand Rapids: Eerdmans, 1999). In an essay titled, "Incorporating Women into the History of the Colonial Dutch Reformed Church: Problems and Proposals," New York historian Joyce Goodfriend claims that Maria Van Rensselaer serves as a prime example of the importance of religion to Dutch women. Van Rensselaer's correspondence, utilized in other chapters of this dissertation, contains what Goodfriend labels "a common religious vocabulary" with family members in Holland. (21).
} 
at least eighteen feet wide, with brick fronts and pan tile roofs." ${ }^{14}$ During the eighteenth century wealthier citizens with established fortunes eventually upgraded their homes to include more pretentious features, such as Rensselaerswyck's acres of beautiful parks and gardens, ornamented in the Dutch style.

Nicholas Van Rensselaer died unexpectedly on November 12, 1678, and the inventory of his estate provides a glimpse of the couple's holdings. Nicholas was found to have a house and lot in Albany, " 50 beavers, 400 guilders; 13 pictures with the King's Arms and an Almanack, 80g. About 200 books, quarto and octavo, the most of them in Strainge Lanuagages; and a brass pocket watch out of order, $200 \mathrm{~g}$. Total 4.344 guilders." ${ }^{\text {15 }}$ Van Rensselaer's possession of literature is particularly unusual, as many Dutch households cherished only a family Bible or catechism. Household goods were also plentiful at Rensselaerswyck, including “'five chany plates,' six cups, nineteen fine earth platters, twelve butter-dishes, two earthen salt cellars, eight fine little earthen dishes, two ditto flower-pots, one ditto can and one ditto mustard-pot." Household linens included "twelve pairs of sheets, sixteen pillowbeers, and four large ones, and a cloth to hang before a chimney, all worth together twelve beavers." Pewter and more expensive goods also abounded in Nicholas and Alida Van Renssealer's home, including "seventeen small and great pewter

${ }^{14}$ Diana S. Waite, ed., Albany Architecture: A Guide to the City (Albany: Mount Ida Press, 1993), 30-31.

${ }^{15}$ Abstracts of Wills on File in the Surrogate's Office, City of New York Volume I: 1665-1707 (New York: New York Historical Society, 1892), 68. 
platters, two dozen plates ... two pewter candlesticks, four dozen cans or tankards, and four dozen small cups." ${ }^{16}$ English visitors to Albany were often shocked by the number of paintings and pewter items found in even the most economical of Dutch households. The Dutch, unlike their new English neighbors, were willing to sacrifice in other areas to afford beauty for their homes. Thomas Sayre of Southampton left to his eldest son, Francis, among other things, "a pewter flagon, a pewter bowl and a great pewter platter," and his son, Daniel, 5 acres and "one great Pewter Platter." Samuel Drake of Eastchester left his daughter, Mary, "2 pewter platters."17 Mrs. Anne Grant notes that prominent families, "carried about them the tokens of former affluence ... such as family plate, portraits of their ancestors executed in a superior style, and great numbers of original paintings." Family plates were often made of pewter and prized almost as highly as silver in wealthy Dutch homes. ${ }^{18}$

In 1679, Alida married Robert Livingston and the newlyweds settled into Nicholas Van Rensselaer's dwelling in downtown Albany. ${ }^{19}$ Unlike the Schuylers and Van Rensselaers, Livingston did not boast a hearty bank account or numerous land acquisitions. He was, in fact, a Scotsman in a Dutch-dominated society which presented immediate and obvious roadblocks to success. He did,

16 Singleton, Dutch New York, 115, 142.

17 Abstracts of Wills I, 16, 134.

18 Grant, Memoirs, 20.

${ }^{19}$ The Livingstons and Schuylers engaged in a heated dispute with the Van Rensselaer family over control of Nicholas Van Rensselaer's estate. Robert Livingston laid claim not only to Nicholas's fortune but also two of his homes. This topic is addressed in detail in chapter four. 
however, possess tenacity and important social contacts with the Cortlandt, Schuyler and Van Rensselaer families. Marriage to one of the city's most eligible widows cemented Livingston's place in Albany society and Alida Livingston, only twenty-four years of age, became a member of yet another prosperous Albany family. Like her mother, Alida spent much of her remaining life assuring that her sons - and daughters- possessed the necessary financial attributes for attracting prosperous mates.

In 1699, the couple completed the building of a manor house on 160,000 acres of land granted to them by Governor Thomas Dongan. No drawings or detailed descriptions of the Livingston's manor house remain. However, a rare general description reveals the manor house as, "relatively large but plain . . . a long, low stone house with thick walls and a heavy Dutch-style roof." Livingston historian Cynthia Kierner notes that heir Peter Livingston demolished the manor house in 1799, exactly one hundred years after it was built, in favor of building a larger and more ornate dwelling. Like most early manorial families the Livingstons built the original dwelling to house a family and a business and focused little on style. The move from Albany to the manor house left Alida Livingston without a close social network or familial protection during Robert Livingston's frequent business trips to New York City. The Dutch custom of sitting on the family stoop in the evenings, eating dinner and visiting with neighbors, was a far cry from life in the midst of Livingston Manor's isolated 160,000 acres. For Alida, life at the manor was lonely and characterized by hard work and almost constant economic strain. For Robert, his wife's constant 
presence at the manor proved a godsend. While Robert managed the couple's trade ventures in New York City, Alida managed, and exponentially increased, the many resources of Livingston Manor, allowing her children to experience the only standard of living she had ever known. ${ }^{20}$

Though most of Alida Livingston's letters contain reference to material goods, it is difficult to discern which items she purchased as stock for the manor's store and which items supported the family's lifestyle. In an October 1711 missive to Robert, she notes the shipment of "a trunk . . . with our silver." Few Dutch families could afford silver, and in the New Netherlands, silver frequently disappeared from the homes of the wealthy due to theft. Alida may have sent the silver to New York for Robert's use in entertaining but most likely sent it for safe keeping. ${ }^{21}$ In 1717 , the Lord and Lady of the manor also splurged on portraits, an unusual expenditure for the parsimonious couple. Portraits were rare in Dutch homes in New York, even during the early eighteenth century. Though the number of paintings in Dutch homes surprised English visitors, very few of these paintings were portraits of individuals. The Dutch preferred landscape paintings and artwork that depicted the world in which they lived. Unfortunately, Alida's perception of herself did not match that of her unnamed artist. Concerned that her portrait did not reflect her modesty, of which Dutch women were very proud, she wrote Robert, "I send you my picture/painting I

${ }^{20}$ Kierner, Traders and Gentlefolk, 134.

${ }^{21}$ Singleton, Dutch New York, 111-112. Singleton notes that Dutch families affluent enough to own silver often used it only on special occasions. This may have been due to the fear of theft, as the courts frequently judged cases involving the theft of silver. 
request that the dress be changed to a less tight dress the neck not so bare and the clothes darker ..."22 No confirmed portrait of Alida Livingston has survived, but it is clear that clothing and appearance mattered to the matriarch.

The clothing purchased by Alida for her children also offers a glimpse into the family's social prominence. Based on the Livingstons' letters, Alida occasionally purchased fine clothing but usually limited her spending to items for special occasions. During the early years of their marriage, Alida's frugality was both necessary and evident. In May of 1698 she wrote, "Marghriet would love to have $61 / 2$ geert small silver fringe if you want to buy it for her and as much handsome silk as for a dress at the manner but I don't know if we can afford it." ${ }^{23}$ Most of these items came from New York City via Robert, from whom she requested items such as, "fine cloth for Ghijsbert as needed for a garment." A few days later Alida added, "Gijsbert would like a pair of shoes..." and in the post script, "Gijsbert wants a light wig." Prior to son Robert's nuptials, she instructed her husband, "In case Robbert gets married have a good garment made for $\operatorname{him} \ldots$. ."24

${ }^{22}$ Esther Singleton, Social New York under the Georges, 1714-1776 (New York: D. Appleton and Company, 1902), 89-90; Alida Livingston to Robert Livingston, 26 October 1717.

${ }^{23}$ Alida Livingston to Robert Livingston, 17 May 1698. The Livingstons could probably afford to barter for the items, but cash was apparently scarce.

${ }^{24}$ Alida Livingston to Robert Livingston, 1 September 1711; 3 September 1711; 26 October 1717 . It should be noted that Alida's spelling often varied, most likely due to the haste with which she wrote her letters. This probably accounts for the numerous spellings of Gilbert's name. 
The Livingstons younger sons enjoyed the trappings of wealth, a source of dismay to the elder Livingstons who associated the accumulation of wealth with frugality and wise expenditures. In April of 1713 , Robert informed Alida, "I am not well-satisfied, that I have to give so much money now for such unnecessary expenses like for wigs, black clothes, etc. It's a shame, but what shall one say? Being silent is best, but it goes to my hart [sic], frankly. I will say nothing more." Robert's complaints referred to his son, presumably Robert, whose purchases of clothing and wigs had exceeded his father's boundaries of acceptable spending. When the Livingstons did purchase items, however, they purchased the very best. In September of 1711 Robert purchased a number of goods, most likely for son Gilbert's impending December wedding, noting, "There is no finer cloth in New York than [what] I have sent up now ... I will try and get good buttons and gold-thread and everything that he needs. ${ }^{25}$ Though both Robert and Gilbert often exceeded their parent's financial boundaries, marriage was an important affair: the Livingstons would not have dreamed of providing their sons with an improper wedding suit.

Alida's replication of what she had learned in the Schuyler and Van Rensselaer households extended beyond clothing and material goods to far more serious matters. Like other wealthy families in Albany, the Schuyler and Van Rensselaer families employed slave labor on their estates. Jeremias Van Rensselaer purchased a male slave from Peter Stuyvesant in 1644 and in 1646

${ }^{25}$ Robert Livingston to Alida Livingston, 9 April 1713; 15 September 1711. Robert's letter of April 9, 1713 does not state which son had indulged in improper spending, but earlier letters suggest it was Robert. 
the patroon of Rensselaerswyck advanced "Jan de Neger" $f 35$ for executing a criminal named Wolf Nijssen. ${ }^{26}$ Wealthy Albanians found no censure from the Dutch Reformed Church for their participation in slavery, though the church afforded slaves certain privileges unavailable in other colonies. In her study of slavery in New York, Leslie Harris notes the church supported slave marriages but forbade slave baptisms - and therefore church membership -after $1655 .{ }^{27}$ Though Anne Grant described New York as a colony where "even the dark aspect of slavery was softened into a smile," it is doubtful that slaves at Livingston Manor - or anywhere else in New York - would have confirmed Grant's analysis. ${ }^{28}$ When the Livingston family moved to the manor house in the fall of 1699, they faced the daunting process of cultivating and clearing a vast acreage for planting and building. While indentured servitude offered a temporary solution to the problem, most white workers in New York quickly established their own farms or engaged in trade, leaving a shortage in the white labor force. Prior to 1763, areas of New York accustomed to Indian attacks, such as Albany and Schenectady, experienced low population growth. As a result, labor costs increased, making it difficult for even wealthy citizens to procure workers and New Yorkers increasingly turned to slaves during the colonial period. By 1746 ,

${ }^{26}$ A.J.F. Van Laer, ed., Van Rensselaer Bowier Manuscrips, Being the Letters of Kiliaen Van Rensselaer, 1630-43, and Other Documents Relating to the Colony of Rensselaerswyck (Albany: University of the State of New York, 1908), 835-836.

${ }^{27}$ Leslie M. Harris, In the Shadow of Slavery: African Americans in New York City, 1626-1863 (Chicago: University of Chicago Press, 2003), 21-22. Europeans viewed the enslavement of Christians as immoral, hence the ban on slave baptisms.

${ }^{28}$ Grant, Memoirs of an American Lady, 41. 
slaves constituted fifteen percent of New York's total population. ${ }^{29}$ For the Livingstons, few resources existed due to the manor's remote location. The couple employed Indians, Palatine refugees and slaves to cultivate fields, complete needed repairs and assist in the manor's milling operations. In September of 1711, Robert wrote, "[l] hope that Vreks, the miller, will have taken good care of the dam and the partition-door before the winter. Make the negroes or Palatines be employed in it, for it is of great importance." ${ }^{30}$ While the Livingstons did not participate regularly in slave importation, they established a precedent of slave ownership and treatment at the manor early on. In addition to directing the manor's store, gristmill, sawmill and agricultural production, Alida sustained responsibility for oversight of the manor's slave laborers. Livingston records do not indicate how many slaves the couple owned at one time, but historian Roberta Singer notes that the family owned at least forty-four slaves prior to Robert's death in 1728. Oversight of the family's slaves took a toll on Alida Livingston, who in 1711 complained to Robert, "It is too much for me to oversee so many negroes." ${ }^{31}$ Robert's will of 1722/23 listed seventeen slaves,

29 Edgar J. McManus, A History of Negro Slavery in New York (New York: Syracuse University Press, 1966), 42. The Dutch West India Company noted, as early as 1647, that white settlers in New York became engaged in trade so quickly that slave labor became necessary to cultivate the land for agricultural purposes. "Board of Audit of the West India Company, 1647," in McManus, Negro Slavery, 1.

${ }^{30}$ Robert Livingston to Alida Livingston, 21 September 1711. In footnote 7, van der Linde comments that the term negro was commonly used in place of slave through the eighteenth century.

${ }^{31}$ Alida Livingston to Robert Livingston, 9 November 1711. It is not clear how many slaves Alida managed, but thousands of Palatine refugees also settled at Livingston Manor during this time, which undoubtedly pushed the Livingston matriarch to her limits. 
nine of whom were "now at ye manor house."32 Alida's responsibilities included the medical care, clothing and housing of the manor's slaves. In May of 1717, she requested that Robert send his old shoes, as well as those of their son, Robert, to the manor for slave use. Robert replied by sending, "shoes for Bettie and Christyn and 2 pairs of mine for the boys." ${ }^{33}$ Alida noted that Joe, the only slave referred to by the couple as skilled, was so ill that she "gave him a vomit drink and made him bleed and then sweat." Robert's 1728 will listed Joe as a "miller," which made his recovery essential to the running of the family's gristmill. ${ }^{34}$ The couple could not afford to lose a slave who worked independently and possessed skills rare to even white laborers, even if his work at times left something to be desired. In a May 13,1717 , missive to his wife, Robert noted that the latest batch of cornel milled by Joe, "has to be rebolted: it contains a lot of coarse bran; and it's merely slackness!" Alida addressed the matter with "Syoo" and Minck and reported, "He promises to watch out better."

Slavery functioned differently in Dutch New York than in the southern colonies. A trade-centered economy and the absence of large cash crops for

${ }^{32}$ Roberta Singer, "The Livingstons as Slave Owners: The "Peculiar Institution" of Livingston Manor and Clermont," in The Livingston Legacy: Three Centuries of American History (New York: Bard College, 1987), 75-76.

33 Robert Livingston to Alida Livingston, 13 May 1717.

${ }^{34}$ Alida Livingston to Robert Livingston, 3 May 1717; 13 June 1722; Singer, 77. This letter is one of two that were not available in the translations of Adrian Van Der Linde at the FDR Library in Hyde Park, New York. The translation appears in Singer's work. cornmeal.

${ }^{35}$ Alida Livingston to Robert Livingston, 22 April 1717. The term cornel refers to 
export resulted in a unique system of slavery in the northern colony. In A History of Negro Slavery in New York, Edgar J. McManus claims the New York slave system lacked the "mutual hatred" apparent in slave-master relations in many southern colonies, largely because New Yorkers did not equate bondage with color. Free blacks enjoyed many of the same opportunities as their white peers, including property ownership and membership in the New York militia - privileges denied to Jewish residents of the colony. For the Dutch, religion served as a greater impediment to social acceptance than color. In 1644, prior to the English assumption of the colony, the leadership of the New Netherlands established this precedent by freeing eleven male slaves who had honorably served the West India Company, providing them "the same footing as other Free people here in New Netherland . . ." ${ }^{36}$ There is no evidence, however, that the Livingstons ever relinquished any of their property, be it human or material, without a fight. The couple did, however, permit their slaves some amount of autonomy. In a 1710 letter to her husband Alida noted the return of "Negro Tom" who "returned home last night had been to visit his folks." In 1717, she informed Robert, "I have sent you Dehgo I think he should be with you now." Dehgo, or Dego, as he appears in Robert Livingston's letters, appears to have possessed a higher level of trust than the majority of the family's slaves and traveled back and forth between Livingston Manor and New York City in accordance with the couple's needs.

${ }^{36}$ Act of the Director and Council of New Netherland emancipating certain Negro Slaves therein mentioned. Passed 25 February, 1644, in E.B. O'Callaghan, ed., Laws and Ordinances of New Netherland, 1638-1674 (Albany: Weed, Parsons and Company, 1868), 36-37; McManus, Negro Slavery, 11-12. 
Robert Livingston bequeathed Dego to his youngest daughter, Joanna, in his final will of 1728 . Joanna had most likely known Dego for years. Ben, another Livingston slave, also possessed the liberty of traveling locally at Alida's behest, but in October of 1711 Alida recorded, "I could not get our Negro Ben to Tachkanick he is so afraid and I am also afraid when the night falls." A number of Indian attacks in the autumn of 1711 most likely inspired their fear. ${ }^{37}$

While Alida's letters do not record any form of physical punishment to slaves, neither she nor Robert expressed sympathy for negligence on the part of any of their workers, regardless of color. The couple's high demands may have contributed to the escape of two unnamed manor slaves in 1711. Alida records, "Our negroes have been near the Plain. . Philip ... sent Indians after them and did not get them but has Indians out again and there is a firewatch going on and there they may catch them if they wanted to go to Canada." Alida's prediction that the escaped slaves may have fled to Canada proved true. Two years later the Livingston's second son, Philip, finally located the missing laborers. He reported that the slaves "wanted to stay there" and claimed that the only possible hope of forcing their return lay in the possibility of Indian abduction. He noted this was unlikely, as "Indians are quite afraid of the French." ${ }^{38}$ Though male heads of

${ }^{37}$ Alida Livingston to Robert Livingston, 18 October 1710; 26 October 1711; 3 December 1717. Though Alida did not mention what she was afraid of specifically, it is likely she feared an Indian attack. Though the Schuyler and Livingston families were leaders in local Mohawk relations, other tribes - with whom the Livingstons and Schuylers did not maintain close relations - frequently passed through the area. It is interesting to note that Alida did not attempt to force the slave to do something which she herself feared.

${ }^{38}$ Alida Livingston to Robert Livingston, 5 November 1711; Philip Livingston to Alida Livingston, 28 October 1713. 
households typically oversaw the purchase and labor of family slaves, Robert's absences from the manor for business and political purposes left Alida in an unenviable position. During Robert's political and business trips, Alida not only managed - but also sold - slaves on her husband's behalf. When Robert sent two slaves to the manor in the spring of 1714 , Alida recorded, "Jeremie has that negro boy who knows English for $£ 50$ he will pay us when you get here and the other one was too small ... so . . . you should send up a big one." Despite the second boy's stature, Alida wrangled $£ 50$ for him, as well. McManus notes that an able bodied male slave typically sold for $£ 40$ in 1700 and $£ 60$ in 1720 . Therefore, Alida's selling price, particularly for the "small" slave, met and exceeded standard market values. Her ability to bargain with local men over the price of human cargo is a strong, albeit uncomely, testament to her entrepreneurial abilities. Sadder still was her response to her fourth son, Gilbert's, mortal beating of a runaway slave in 1721 . She recounted the event to her husband with the comment that the slave, ten days later, had "died out of doggedness." The consequences of Gilbert's actions worried his mother, but she expressed little mercy for the slave who had, in her mind, simply died to vex his owner. $^{39}$

${ }^{39}$ Alida Livingston to Robert Livingston, 21 May 1714; 22 April 1721; McManus, Negro Slavery, 43; Singer, "The Livingstons as Slave Owners," 83. Alida's son, Philip Livingston, became an ardent slave trader during the 1730s, after the death of both of his parents. For more information on Philip Livingston and the slave trade, see The Transatlantic Slave Trade: A History by James A. Rawley and Stephen D. Behrendt (Lincoln: University of Nebraska Press, revised edition, 2009). 
Local Indians fared far better with Robert and Alida Livingston than did their slaves. As a newcomer to Albany, Robert Livingston quickly earned a spot as secretary of the Albany Indian commissioners. ${ }^{40}$ Like his father-in-law, Robert's favor with local Native Americans served the couple well throughout their lifetime. Other than forced labor, slaves had little to offer the wealthy couple. Indians, however, proved a valuable resource, both for trade and land acquisition. As a member of the Schuyler family, Alida had already earned the respect of local Mohawks. In April of 1717 she regaled Robert with problems regarding a land dispute with "the Indians," complaining, "I can not find the purchase where the Indians signed, wanted very much to convince them with their own handwriting." Two weeks later, she requested, "... write me where I can find the bill of sale of Pochkonekook so I can convince the Indians." In June of 1722, Robert recorded the sale of two "roers," or long barreled rifles, to local Indians. "[l] hope that the natives will like the 2 roers, and that you will be able to sell the 4 other ones at a profit, for they are cheap." The Livingston and Schuyler family history with local tribes placed Alida in good standing to barter and trade on her husband's behalf. ${ }^{41}$ Alida's interaction with Indians was not unusual, at

${ }^{40}$ For information on Robert Livingston's Native American relations, see Lawrence H. Leder, Livingston Indian Records 1666-1723 (Gettysburg: The Pennsylvania Historical Association, 1956). Robert Livingston's position as Secretary for Indian Affairs provided him with the privilege of viewing almost every piece of Albany legislation dealing with the Iroquois, making him a formidable rival in local Indian affairs. I have chosen to highlight only those Native American interactions involving Alida so as to maintain the focus of this work. It was largely through his association with the Schuyler family that Robert Livingston gained any foothold whatsoever in Indian affairs.

${ }^{41}$ Alida Livingston to Robert Livingston, 22 April 1717; Robert Livingston to Alida Livingston, 5 June 1722. According to Adrian van der Linde's translation notes, Robert uses the word "wilde" in reference to local Native Americans. The word was translated 
least in the Schuyler family. In 1722, John Collins, husband of Alida's sister, Margaret, wrote,

... my wife has been in the Indian country, and Van Slyck had purchased what he could at the upper end of the land; he purchased the rest from Ignosedah ... he has gone through a great deal of trouble and hardship bout it, being from home almost ever since you left us; nd prevailed with the Indians whilst there with trouble and expense. $^{42}$

The couple's letters also reveal that Alida Livingston did not fear direct contact with local Indians. In 1717, she calmly recounted an unexpected visit from "Arie de Wilt/the Indian" who "was here with 12 or 13 Indians and 3 scalps and an Indian from the Carolinas whom they had caught." She continued, "greetings to [daughter] Neatje." Unfortunately, the Indian presence near the manor often included other tribes with whom the family did not appear to have a relationship. In the fall of 1711, Indian attacks caused heightened concern at the manor. "There are senecas and cayouges who are out hunting here who have beaten to death several farmers pigs ... we do not like it at all that those Indians are hunting here but it can be helped." Alida had reason for concern, as she went on to relate, "there is a great black mare in the first settlement the leg and all the

"savages." Though Robert's interaction with local tribes were usually positive, his contempt for the Indians - which is apparent in several of his letters - does not match the respect shown for the Indians by Alida's father, Philip Schuyler.

42 Earle, Colonial Days in Old New York, 161. Earle's extensive history of New York does not include footnotes, only dates and quotations from letters. The name "Van Slyck" most likely refers to relatives of Cornelis Antonisen van Slyck, who married a Mohawk bride and "raised a family that became prominent on the Mohawk frontier." Allen W. Trelease, Indian Affairs in Colonial New York: the Seventeenth Century (Ithaca: Cornell University Press, 1960), 172 
nerves have been cut off it can not live ... several other horses have been cut . . ." Several weeks prior to this letter, Alida shipped personal items, including a trunk and "velvet garment," to Robert in New York, with the explanation that "here is each day alarm they see French Indians then here then there so I am afraid to keep it here. Robert consoled his wife with the hope that the impending winter's snow might, "chase them away."

The world that awaited future generations of Livingston was not the world that the first Lord and Lady of the manor had known. Early Albanians of status such as the Schuylers, Van Rensselaers and Livingstons- utilized slave labor and strong Indian relations as a means of procuring wealth. This wealth permitted the privileged class to purchase property and homes that provided future generations with a foundation upon which to build their own status. Unfortunately, by the mid-eighteenth century women like Alida Livingston gradually disappeared from Dutch society, replaced by children and grandchildren who took affluence for granted and embraced lives of gentility and ostentatious wealth. Many heirs tore down, or remodeled, manorial estates in accordance with their new lifestyles. Despite these changes, Alida Livingston died confident that her efforts had assured her offspring their rightful place in New York society as future lords and ladies of Livingston Manor.

${ }^{43}$ Alida Livingston to Robert Livingston, 22 May 1717; 22 November 1711; 9 November 1711; Robert Livingston to Alida Livingston, 28 October 1711. 


\section{CHAPTER TWO:}

\section{THE ALBANY YEARS}

The English conquest of the Dutch New Netherlands in 1664, the Schuyler family business legacy and the individual personalities of Alida and Robert Livingston formed an unusual setting for a business relationship that survived and flourished - for almost 50 years. Though some historians might categorize Alida Livingston as a "deputy husband," Alida was far more than a substitute business associate for her husband. Throughout her marriage, whether or not her husband was present, Alida managed property and other investments independently and earned a reputation as an economic force with which to be reckoned. It cannot be fairly argued that she was an independent businesswoman, though Alida deserves her due. The couple's correspondence reveals that Alida was more than an independent businesswoman or deputy husband - she was an equal partner in one of early America's most prosperous business empires. ${ }^{1}$

Under Dutch civil law, the Dutch West India Company permitted members of both sexes to participate in colonial business, including the colony's most

\footnotetext{
${ }^{1}$ Laurel Thacher Ulrich presents the concept of "deputy husbands" in Good Wives: Image \& Reality in the Lives of Women in Northern New England, 1650-1750 (New York: Oxford University Press, 1983), Part One, Chapter Two. Deputy husbands were women who managed the family business in their husbands' absences, continuing with business as their husbands would have seen fit. Though Alida Livingston was not solely responsible for all of the family's business ventures, she also rarely received significant instruction from her husband. Indeed, the couple's letters portray a give-andtake relationship where each made equal suggestions, and, when the occasion warranted, offered reprimands, as well.
} 
prosperous venture, the fur trade. However, businessmen - and women - were still subject to the authority of the Dutch West India Company, which maintained tight control over merchants and traders within the New Netherlands. According to New York historian Michael Kammen, "a resident of New Amsterdam could pursue almost no form of economic activity without regulation or supervision" by the company, to protect citizens from "fraudulent practices." ${ }^{2}$ The company also frowned on "seasonal traders" whose encroachment on local merchants and sale of inferior products resulted in the establishment of burgher rights in the New Netherlands during the 1650s. Burgher rights, reserved for local citizens, did not openly exclude women, though most wives were granted burgher rights with their husbands or "inherited the privilege from fathers." In New Amsterdam, only those designated as burghers could conduct business within the city limits, which most certainly limited rural women's participation in public enterprise. Historian Simon Middleton claims, "There is no shortage of evidence that women of all ages ... engaged in commerce ... but public recognition of women's work and female skills was limited to ... midwifery and housekeeping." Dutch women ran businesses independently, but were primarily wives and mothers. ${ }^{3}$ Though Alida was born in a colony governed by Dutch civil law, by the time of her marriage to

\footnotetext{
${ }^{2}$ Kammen, Colonial New York, 56-67; Middleton, From Privileges to Rights,38, 47.

${ }^{3}$ Ibid, 47.
} 
Robert in 1679 the English conquest of the New Netherlands had resulted in New York's transition to English common law, which viewed the rights of women very differently. The conversion to common law was slow, however, and Alida Livingston's economic contributions to the Livingston fortune were similar to those of her Dutch ancestors in many respects. ${ }^{4}$

Though colonial life was undeniably difficult, regardless of wealth or status, the social status maintained by Alida's family certainly eased the hardships. Alida's maternal grandfather, Brant Arentse Van Schlectenhorst, was one of the first directors of Rensselaerswyck, a property which surrounded the city of Albany and was the largest - and most successful - Dutch patroonship during the early years of settlement. ${ }^{5}$ Enlarging upon the skills she had obviously learned as Schlectenhorst's only daughter, Alida's mother, Margarita, assumed

${ }^{4}$ Sir William Blackstone, Commentaries on the Laws of England In Four Books; With an Analysis of the Works (New York: W.E. Dean, 1840), 349. One hundred years later, William Blackstone commented, in regard to English coverture and marriage, "they are one person in law, so that the very being and existence of the woman is suspended during the coverture, or entirely merged and incorporated in that of the husband."

5 Stefan Bielinski, Rensselaerswyck, taken from http://www.nysm.nysed.gov/albany/na/rensselaerswyck.html\#borders last accessed 22 January 21 2010; Sung Bok Kim, Landlord and Tenant in Colonial New York: Manorial Society, 1664-1775 (Chapel Hill, NC, 1978), 36; Samuel G. Nissenson, The Patroon's Domain (New York: Columbia University Press, 1937), 381-385. Rensselaerswyck was founded in 1629, and although other patroonships ended this property remained in the Van Rensselaer family for generations. In 1685, Kiliaen Van Rensselaer was given a patent that extended the Manor to almost one million acres. The original 1629 patent did not state an exact amount of land, but rather gave landmarks to define the property. The original patent is printed The Patroon's Domain, 381-385 and the original copy is available in the New York Colonial Manuscripts at the New York State Archives. 
control of the Schuyler family estate upon the death of Alida's father in 1683, "and managed the large property for about twenty-eight years." ${ }^{16}$

By the time of Margarita's death in 1711, "she had administered the estate with such success that it had become one of the largest in the province." Her wealth and tenacity were well known in Albany, where she served as a trader and financial supporter of the colony until her death. In his history of the Schuyler family, George Washington Schulyer notes her "liberal benefactions" to the Dutch church at Albany." Margarita also contributed to the colony's defense in May of 1689, when Jacob Leisler, a German-born colonial merchant and militia captain, captured Fort James at the tip of Manhattan Island and lead an insurrection against the English-appointed lieutenant governor, Francis Nicholson. When Leisler threatened to gain control of Albany, "she was on the side of law and order" and advanced money to the Albany city treasury to help pay for the city's defense against him. ${ }^{7}$ Like her daughter, Margarita maintained a clear head for business, even in the midst of rebellion. '"Mrs. Schuyler was willing to advance eighteen pounds, (the sum required), one month without

${ }^{6}$ Schuyler, Colonial New York: Philip Schuyler, 167; Biemer, Business Letters, 184.

7 Jacob Leisler was executed for his involvement in the plot. Leisler was particularly opposed to Albany - and the Livingston and Schuyler families - because Robert Livingston and Peter Schuyler headed the Albany Convention, his main opposition in New York. Leisler attempted to incite the working classes against the more aristocratic families. It must be noted that this is the same Jacob Leisler who brought accusations against Alida's first husband, Nicholas Van Rensselaer. For more on Leisler's Rebellion, see David William Voorhees, "The fervent Zeale of Jacob Leisler," The William and Mary Quarterly, Third Series, 51, No. 3 (1994), pp. 447-472. For further details on the rebellion, see Robert C. Ritchie, The Duke's Province: A Study of New York Politics and Society, 1664-1691 (Chapel Hill: University of North Carolina Press, 1977), Chapter 9 and Jerome R. Reich's study, Leisler's Rebellion: A Study of Democracy in New York, 1664-1720 (Chicago: University of Chicago Press, 1953). 
interest, and if not then returned moderate interest thereafter." She advanced the money, but as it was not a gift she was careful to have a bond signed by the officers of the convention." ${ }^{8}$

Margarita's defense of the colony was not limited to mere financial gain. According to Schuyler, Alida's disposition and strength of character were clearly inherited from her mother. When Jacob Leisler sent commissioners to Albany during the rebellion, he found that the men - and women - of Albany did not appreciate their presence. In May of 1690, Leisler writes, ... adversaries have not only in ye towne but all ye Country over to or great grief spread abroad that nothing was done but drinking and that thereby when ye Indians where there was caused Sutch disturbance that ye widou Scuyler beat Capn Milborne \& that you where all three forced to fly out of ye Towne \& where gone to Esopes."

In her last will and testament Margarita made one final stand of independence by ignoring the English custom of primogeniture, which would have left the bulk of the family's fortune to her eldest son, Peter. Instead, she split the family inheritance equally among her eight surviving children, including her daughter, Alida. ${ }^{10}$ By the time of her mother's death in 1711 , however, Alida Schuyler Van

${ }^{8}$ Schuyler, Colonial New York, 168-169

${ }^{9}$ Leisler to His Agents at Albany, from Fort William May $19^{\text {th }}, 1690$. E.B. O'Callaghan, ed., The Documentary History of the State of New York, Volume II (Weed, Parsons \& Company, Public Printers, 1849), 247.

${ }^{10}$ Schuyler, Colonial New York pp. 167-171. Schuyler notes that an absence of records made it difficult to ascertain exactly how the Schuyler family estate was divided by Margarita at her death. Margarita's will notes "Yet, not thinking that my son, Peter Schuyler, would himself endeavor to take any such advantage, he being present at the making of said will. I give to each of our 8 children an equal part of all real and personal estate." 
Rensselaer Livingston had already paired with her second husband, Robert, to become one of the wealthiest - and most influential - couples in colonial New York.

The first phase of Alida and Robert's economic partnership began with their marriage in 1679. In Robert's entry of the couple's nuptials in the family Bible, he refers to his new wife as his "worthy helpmeet," a phrase that perhaps best portrays the couple's relationship throughout their lengthy marriage. ${ }^{11}$ The Livingstons were certainly one of the most successfully matched couples in early New York history. Alida's knowledge of trade and the running of a manor complemented the hard work and dogged persistence that characterized Robert Livingston's personal and professional life. Together, the couple managed a vast amount of land and other property while raising six children to adulthood and consistently increasing their fortune. However, much of the couple's success must be attributed to Alida's conscientious care of Livingston Manor and the couple's financial investments during Robert's frequent stays in New York City. Lawrence Leder argues, correctly, that Alida was "undoubtedly responsible for her husband's success; it was she who ran their storehouse and determined whether or not credit was to be extended. Her effectiveness as a businesswoman is to be found in the increasing sales figures in Livingston's account books." 12

${ }^{11}$ Alida Schuyler's first marriage, to the much older Nicholas Van Rensselaer, will be discussed in length in the chapter on Robert and Alida's marriage.

${ }^{12}$ Leder, Robert Livingston, 247. 
During the early years of their marriage, the Livingstons' correspondence reveals a young couple desperately striving to make a place for themselves in Albany society. Though Robert's marriage to Alida had opened doors to the young Scotsman, the responsibility for the Livingstons success or failure lay squarely on their ability to successfully juggle numerous properties and business investments while beginning a family of their own. Though few of the couple's early letters have survived, the existing missives express the daily frustrations of a working mother and businesswoman. In November of 1680, Alida wrote to Robert regarding the transport of 4 barrels of lard and noted, "Hanse greets [you] heartedly. I hope to see you this week. Written in haste." Hanse, short for Johannes, was the couple's first child, who was then less than a year old. In addition to her duties as a new parent, Alida was responsible for the daily necessities of her small family and her husband's trade ventures in the area. Two years later Alida's responsibilities grew to include the raising of two toddlers, Johannes and Margaret, in addition to administrating the family's local trade. On October $24^{\text {th }}$ of 1682 , Alida reported the children's good health to Robert and detailed the status of "300 well fatted sows" and the delivery of "wine." In reference to Robert's next visit home, she closes her letter with a request to "hurry as much as you can." ${ }^{13}$ Despite Alida's ability to conduct trade in her husband's absence, the couple's frequent separations were obviously a strain on the young wife and mother, who frequently requested her husband's safe - and hasty - return home.

${ }^{13}$ Alida Livingston to Robert Livingston, 21 November 1680; 21 October 1682. 
The late 1680 s and 1690 s were years of blessing and also hardship for the Livingstons. Alida gave birth to nine children during these years, a difficult but common experience for seventeenth century women. As the Livingstons' involvement in trade escalated, their resulting geographic separation resulted in Robert's dependence on Alida for local gossip and political affairs - and there was certainly much to convey. In addition to the colony's severe economic depression, from 1676 to 1695, the formation of the Dominion of New England by James II in 1686 and the Glorious Revolution of 1688, which brought the Dutch William of Orange and his English wife, Mary, to the British throne, also wrought havoc on New York. The Dominion of New England, formed by James II, united the New England colonies under one governor in 1686. In 1688, James drew New York and New Jersey into the Dominion. Though Britain viewed the Dominion as a means of unifying the colonies for military and financial reasons, colonists abhorred the changes administered under the new governor, Sir Edmund Andros. ${ }^{14}$ The colonists - and most of Protestant England - were further dismayed when their Catholic King, James II, fathered a son with his second wife, Mary of Modena, in 1688. Prior to the birth of the baby, who was heir to the throne and would be raised as a Catholic, James's Protestant daughter, Mary, had been heir to the throne. Fearing a Catholic takeover, William of Orange, Mary's husband and chief stadtholder of the Netherlands,

${ }^{14}$ Under the Dominion, colonists had common currency, united defense and a single governor. For further information see Viola Florence Barnes, The Dominion of New England: A Study in British Colonial Policy (F. Ungar Pub. Co, 1960); Mary Lou Lustig, The Imperial Executive in America: Sir Edmund Andros, 1637-1714 (New Jersey: Fairleigh Dickinson University Press, 2002). 
invaded England and in a bloodless confrontation assumed the throne with his wife. ${ }^{15}$ Colonists were shocked when news of the Glorious Revolution reached America. If revolt could be so easy, and highly successful, perhaps the colony could follow suit and rid itself of the burden of a royally-appointed governor and lieutenant governor, Francis Nicholson. Capitalizing on the political chaos, in 1689 militia Captain Jacob Leisler of New York began a notorious two-year rebellion that further strained the Livingstons' relationship.

Leisler's seizure of power concerned Albany's leaders, among them the young Robert Livingston. Albany's positive relations with the local Iroquois - and the protection against the French afforded Albany by this alliance - could easily be destroyed by a zealous leader such as Leisler. When Jacob Leisler threatened to bring the city of Albany under his control, Livingston joined the Albany Convention, a group of local officials united in their goal of keeping Albany out of Leisler's hands, and offered $£ 50$ of his own funds to the city to help provide for its defense. Lawrence Leder claims, "it was Livingston's financial support that, for a time, enabled the convention to maintain its independence of Leisler." ${ }^{16}$ When Livingston was commissioned by the convention to seek military assistance from Connecticut and Boston in March of 1689/90, Leisler

${ }^{15}$ Many English feared a Catholic king would not only challenge the supremacy of the Church of England but also create closer ties with the French. For a more thorough description of the Glorious Revolution and its effect on North America, see David S. Lovejoy's The Glorious Revolution in America (Hanover: Wesleyan University Press, 1987). Chapter 6 deals specifically with the revolution's influence on colonial New York. Mary and William of Orange were cousins, and it was hoped that their marriage would help England form a strong alliance with the Dutch.

${ }^{16}$ Leder, Robert Livingston, 62. 
accused him of owing money to the Crown, resisting authority, and stealing the city's financial records. ${ }^{17}$ In April of 1690, the "commissaries at Albany" informed Leisler,

The Sheriff and County Clerk forwarded also yesterday the Minutes and other Books \& papers etc. belonging to this City and the County of Albany, but found the Registers only to $1^{\text {st }}$ December 1685 . And Robbert Livingstons wife said, she has no knowledge of the others. ${ }^{18}$

As was often the case during her marriage, Alida was left to answer for her husband's actions - and the missing county record- on his behalf. Authorities questioned Alida, searched the Livingstons' home and allegedly discovered, "a priest's regalia and a number of Indian catechisms" which "served as ground for new accusations. ${ }^{19}$ " When the books were not produced, the local sheriff was ordered by Leisler's commissaries to seize Livingston's possessions and treat him as one of "those who abet \& contrive to defraud his Majesties dues and dutyes." For Alida, the assault on her husband's character- and the resulting intrusion of her home- came at a particularly difficult time, as she had just given birth to the couple's fourth son, Gilbert, only a few weeks before. Matters did not improve quickly, and Leisler's hatred of Livingston, as well as Robert's fear of

${ }^{17}$ Munsell, The Annals of Albany, 196-199. The convention's primary purpose in sending Livingston to Connecticut and Boston was for him to procure assistance in Albany's plan to invade "Quebek." Additionally, a Native American raid on the town of Schenectady had left a shortage of meat, and Livingston was instructed to request "Barrells of Porke or Beefe." Leisler hoped to have Livingston arrested in Connecticut, but his plan was unsuccessful.

${ }^{18}$ The Commissaries at Albany to Leisler 2 April 1690, in Doc Hist II, 205; Henry R. Stiles, The New York Genealogical and Biographical Record Volume XXXII (New York: New York Genealogical and Biographical Society, 1901), 132.

${ }^{19}$ Genealogical and Biographical Record, 132. 
imprisonment, led Livingston to live in exile in Connecticut until 1691. Alida temporarily remained in the colony where she was subjected not only to the daily rigor of raising a family, but also to the strain of ever-increasing economic and safety issues within Albany. The decline of the fur trade and the persistent threat of a French or Indian assault during King William's War plagued all the citizens of colonial Albany, but the danger to a young mother living alone was great indeed. $^{20}$

Upon his return to New York in 1691, Robert Livingston gained the favor of the newly arrived Governor, Henry Sloughter, who had ended Leisler's Rebellion. Sloughter's respect for Livingston led him to appoint Livingston as commissary for the colony's royal troops garrisoned at New York City and Albany. The position of commissary was a risky one. Once a commissary had contracted with the government, he supplied the troops from his personal funds and hopefully awaited repayment. Unfortunately, the Livingstons were not always paid in cash and in Robert's absences his duties fell to Alida. Without cash, the difficulty of supplying the troops with food and other necessities became an increasing burden to the family. In April of 1692, Alida voiced her financial worries in a letter to Robert, who was conducting business in New York

${ }^{20}$ Doc Hist II, 218. Leisler's allegations that Livingston owed the Crown was false, and the warrant for his arrest was questioned by Governor Treat of Connecticut, much to Leisler's dismay. The arrest warrant was so unclear that Treat was not willing to damage his own career for Leisler. Robert returned for Alida and the children and took them to Connecticut for the winter for protection. 
City. "If you intend to stay . . look for a good employ also, for here is nothing to do." 21

From December 10, 1694, to August 2, 1696, Alida again managed the family business in New York on her own while Robert and the couple's eldest son, Johannes, traveled to Europe to deal with Livingston family affairs. In addition to financial matters, Robert Livingston planned to deal with ongoing convictions from the Leislerian affair as well as an admiralty case against him for an alleged illegal trading venture on his brigantine, Orange. ${ }^{22}$ Robert granted his wife power-of-attorney on October 22, 1694, entrusting the running of the family business to her care. The five week voyage was unexpectedly extended to five months when the ship's rudder was "knocked off" during a storm that raged on the Atlantic for three weeks. Fortunately, Robert and Johannes survived several attempted mutinies and thefts to arrive safely in Portugal on May 8. Alida's dismay at her husband and son's misfortune was further exacerbated by her husband's forced removal from local public affairs. While in London, Livingston bore "lurid testimonials" against New York's Tory Governor, Benjamin Fletcher.

${ }^{21}$ Leder, Robert Livingston, quotation from April 7, 1692 letter from Alida to Robert. I could not find this letter in the translations of Jos Van der Linde, and have therefore used the translation as noted in Leder's text, p. 83. Though the job of commissary could be financially rewarding, if repayment was consistent and on time, it was an often thankless job paid on a per soldier basis. The difference between the funds provided per soldier and the amount for which Livingston supplied them was Livingstons to keep. Unfortunately, this meant that soldiers' typically received only the barest of necessities.

22 Ibid, 93-94. The Orange, of which Livingston was a co-owner, had allegedly been seized by the French on Hispaniola and returned with only $25 \%$ of its original cargo. Upon its return to New York, however, the Orange had mysteriously attained more goods than it set out with, and Livingston was expected to answer for this illegal trading venture. 
The Whigs, to whom Robert pled his case, exonerated him of all charges but unfortunately referred payment of his debts to Fletcher, who had no interest in repaying his political enemy. When Robert returned to New York in August of 1696, he focused on commerce while Alida remained in Albany, where she became her husband's primary source of information and the recipient of much unmerited gossip on her husband's behalf, due to his "political apostasy."23 When word reached the colony that the Richard Coote, the $1^{\text {st }}$ Earl of Bellomont and a Whig, was to replace Fletcher as governor, hostilities flared in Albany. Fletcher's distribution of Indian lands to particular citizens of the community during his administration had enraged Albany's citizens, who turned to their aldermen for assistance. These aldermen, in turn, requested the assistance of Robert Livingston in presenting their case to the incoming governor. One of the patentees, Dirk Wessels, who refused to transfer his patent to the town of Albany, earned Alida's ire by spreading rumors about Robert's character. "I am amazed how you can still speak well of Dirk as he is such a great enemy of yours ... they have set the people against you but now they begin to see better that they smeared you with lies and that they are out for themselves." Though Alida's letters do not mention the content of all of these rumors in detail, she did note that one rumor circulating throughout Albany

${ }^{23}$ Ibid, 96-99, 116-118, 124; Kierner, Traders and Gentlefolk, pp. 33-36; Petition of Benjamin Fletcher to Council of Trade and Plantations, J.W. Fortescue, ed., Calendar of State Papers, Colonial Series, American And West Indies, 27 October 1697-31 December 1698 (London: Mackie \& Co., LD, 1905), 333; Robert Livingston to Earl of Bellomont re: request for payment of Livingston's withheld salary, 12 September 1700 in LRMSS. Arnold J.F. Van Laer has translated Livingston's lengthy journal of the trip, which details the attempted mutinies and hardships the Livingston men suffered on their journey. The journal is part of the Livingston-Redmond MSS. 
claimed that Livingston had quarreled with a Mister Broek and had "said of him then that he was the son of a pair of pants and that he was a foundling." She added, "I think that you would be wiser than to say such things even if it was true." In contrast to Alida's usual fortitude, she complained, "it saddens me to live this way, and that you have been away from me for so long." ${ }^{24}$ Thirteen days later, the situation in Albany was "now quiet" but severe weather had resulted in "animals at several places ... freezing to death in their stalls." ${ }^{25}$ Alida Livingston, stressed to the point of breaking by her husband's affairs, could scarcely afford another disaster.

The increasing rumors and "lies" about the Livingston's situation increasingly took its toll on Alida. In a second letter to Robert dated January 25 , she stated, "if you are not continued in your service . . . then I will not live amongst these people . . . it is a changeling people, one cannot count on them." The furor over Fletcher's granting of Indian lands to his favorites within the Albany community continued, and, as citizens divided over the issue, the local dominie became embroiled in the dispute. Alida spared little mercy for him, and informed her husband, "You have no greater enemies as ... Dominie. I wished that we had one who only concerned himself with the church." The dominie's involvement in spreading her husband's misfortunes was unacceptable to Alida, who was hurt by the gossip that her husband was "not well regarded" by the

${ }^{24}$ Alida to Robert Livingston, 12 January 12 1698. Though Alida Livingston did not detail the rumors surrounding her husband, it is obvious that Livingston's appeal to the new governor in regard to Fletcher's patent distribution stirred up animosity by the patent's owners, including Dirk Wessels.

${ }^{25}$ Alida to Robert Livingston, 25 January 1698. 
Governor. ${ }^{26}$ Additionally, Alida had to deal with the fact that some of her neighbors believed that Livingston's appeals on behalf of Albany's aldermen would prove unsuccessful and a waste of money. By February, the situation had not improved and Alida expressed continued sadness at Robert's lengthy absence. In regard to the patent issue, she reported, "here is no news but trouble in the community against them who have the patent." Alida, pregnant with her ninth child and "quite uncomfortable," was becoming increasingly tired of the situation. Though Alida had hoped to relieve some stress with a relaxing trip to Taogkanick with friends, one of the rare instances in her letters where she mentioned a day of rest, the trip was canceled due to severe snow. ${ }^{27}$

In March, her letters to Robert contained the usual family business as well as the declaration, "it saddens me to be without your comfort in the condition that I am, but I will find my consolation in God." Fortunately for the couple, governor Bellomont arrived in April of 1698 and took an instant liking to Robert Livingston. Within two weeks, the new governor required Fletcher to defend his charges against Livingston and the matter quickly ended in Livingston's favor. The charges - that Livingston had cost Fletcher his position by telling tales in England-were weak, and Fletcher chose not to appeal his case before the new Governor. Rumors regarding Livingston's relationship with the new governor were quickly put to rest, as well. On October 21, 1698 Governor Bellomont wrote

${ }^{26}$ Alida to Robert Livingston, 27 January 271698.

${ }^{27}$ Alida to Robert Livingston, 8 February 8 1698. Alida's reference to "Taogkanick" refers to what is today known as Taghkanic. When the Livingstons were granted Livingston Manor in 1715, "Taogkanick" became part of their estate. 
to the Council of Trade and Plantations in London to note that he had appointed four new councilors, among them Robert Livingston. "The Government is under no small obligation to Mr. Livingston, for, but for him, the four companies would long since have deserted ... I could find no one would subsist them except Mr. Livingston." That Bellomont did not know Livingston well is evident in his further comment, "Purely to serve the Government and avert the disgrace and mischief of the soldiers' desertion he undertook the charge." ${ }^{28}$ The couple's political victories were laced with personal sadness for the couple, however, as Alida informed Robert of the birth of a very sickly child in June. Sadly, the new baby, christened Catharina, died in December of 1699. ${ }^{29}$

The couple had many difficult years from 1699-1709, though Alida Livingston's correspondence is sadly missing for this period. While in London in 1695, Robert Livingston had invested in the Adventure Galley, a ship operated by the alleged "pirate" and privateer Captain William Kidd. ${ }^{30}$ Kidd, hired by Livingston and others to stop piracy, was promptly accused of piracy in 1699 upon his arrival in New York. His subsequent trial and hanging in London were a

${ }^{28}$ Leder, Robert Livingston, pp. 130-131; Cal. S.P., pp. 487. "Governor the Earl of Bellomont to Council of Trade and Plantations," 21 October 1698.

${ }^{29}$ Alida to Robert Livingston, 6 June 1698; 13 June 1698; Leder, 129-133. Alida's referral to the child as "it" appears somewhat heartless in modern culture, but was not uncommon for a child who had yet to be christened and was, in addition, suffering from a potentially life-threatening illness. Robert was not only cleared of Fletcher's accusations against him, he was also endorsed by the new governor, Bellomont, to a position on the governor's council and given the opportunity to victual royal troops at Albany yet again.

${ }^{30}$ Leder, Robert Livingston, 125. For a detailed account of Captain Kidd's career, see Robert C. Ritchie's Captain Kidd and the War Against the Pirates (Cambridge: Harvard University Press, 1986). 
public embarrassment to Livingston, as Kidd's accusers had intended. Then, in March of 1702, Livingston's refusal to answer to the New York Supreme Court on the primary charge of using public funds for his own affairs, a charge made by the Leislerians, resulted in the temporary confiscation of his New York City property. When the arrival of another new governor, Lord Cornbury, in 1702, failed to right all of Livingston's financial and political issues, Robert made a second trip to England where he remained from the summer of 1703 to September of 1706 . Livingston hoped to secure payment for various debts owed him by the government, including his victualing contract for the British soldiers. ${ }^{31}$ As was common during their marriage, Alida remained at home to oversee the family's business and private affairs during her husband's extensive absence. Upon Robert's return, the couple gradually settled into a more private lifestyle until events abroad pulled the Livingstons into yet another financial trauma.

In 1709, the War of Spanish Succession left many Germans from the Palatinate in dire straits after repeated attacks on their lands by Marshal de Villars of France. Many Palatines, with "not so much as a house to hide their heads in, nor hardly cloaths to cover their nakedness," fled to England for refuge. Queen Anne and the Whig Ministry willingly offered shelter in New York for thousands of Palatines, with the intention of using them to produce naval stores for Britain. ${ }^{32}$ The population of New York also needed bolstering, and more

\footnotetext{
${ }^{31}$ Ibid, 177-178, 182, 185-199.

32 Ecclesiastical Records, "The Palatine's Catechism or a True Description of Their Camps at Black Heath and Camberwell," 1817-1820; "An account of the
} 
citizens meant more adult men to protect the colony against a potential French assault. In 1710 Robert Hunter was designated as the new governor of New York. He sailed to the colony with 2,814 Palatines, of whom 470 died on the voyage. On arrival Robert Livingston quickly befriended Hunter. ${ }^{33}$ Faced with the daunting task of providing shelter and food for the emigrants, Hunter purchased 6,000 acres from Robert and Alida for the sum of $£ 400$, noting, "It has these advantages besides the goodness of the Soile, that it is adjacent to the Pine which by the conveyance we are Intituled to, and a Place where Ships of 50 foot water may go without difficulty."34 The formal deed, dated September 29, 1710, noted that the arrangement was made between Queen Anne and "Robert Livingston of the Manor of Livingston ... and Alida his wife." A memorandum to the deed, dated October 5, 1710 notes that "Allida the wife of the within named Robert Livingston . . . being Secretly and apart Examined by me Declared her Consent to the within written deed. ${ }^{35}$ In addition to the purchase, which firmly

principality called the Palitinate," 1821-1823; Palatines to the Tradesmen of England, 1823.

33 Mary Lou Lustig, Robert Hunter 1666-1734: New York's Augustan Statesman (New York: Syracuse University Press, 1983), 69-71; Ecclesiastical Records, "Covenant for the Palatines Residence and Employment in New York," 1814-1816. Despite their ups and downs, Livingston and Hunter maintained a fairly positive relationship during most of Hunter's years as governor, which was financially profitable for the Livingston family.

${ }^{34}$ Same to the Same, Lond. Doc XVIII, dated October 3, 1710. Doc Hist III (Governor Hunter to Board of Trade), 338.

${ }^{35}$ Ibid, pp. 386-390. Deed of the land now constituting the town of Germantown, Columbia County, N.Y. It must be noted that Alida's consent to the sale of land was questioned by one "P. Schuyler," a relative. A women's consent would usually have been taken for granted, but Alida's relatives undoubtedly hoped to protect her. 
cemented the Governor's friendship with Livingston, Hunter also named Livingston "inspector of Palatines" and granted him a victualing contract to provide for the Palatines,

The Quantity of Bread Equall to one third of a Loaf of bread...\& one Quart of Beer such as is usually called ships Beer...The sd Robert Livingston His Execrs \& Admrs shall at or before the Expiracon \& end of every two Months be fully paid... half part in Current Silver mony of the Province...And one other Moietry of half part in . . . merchantable Goods Wares \& Merchandizes.

The arrangement between Hunter and Livingston, which no doubt appeared profitable to Livingston at the time, resulted in increasing financial concerns for Robert and Alida when they did not receive repayment for victualing the Palatines. Despite Robert Hunter's contract with Livingston, which promised, "to pay and satisfie... Robt Livingstons ... for the ... bread and beer," the endeavor, which helped to clear the streets of London of at least some of the Palatines, was ill-fated from the beginning. ${ }^{36}$

On October 21, 1710, Robert informed his wife, "we have to brew from here on in shipsbeer for the Palatines each a quart daily is 900 gallons daily . . .${ }^{37}$ Because of Robert's work in New York City, Alida assumed responsibility for fulfillment of the Palatine contract, an unenviable job. Of the refugees who arrived in New York in June of 1710, a large number were women or children under the age of 14. Unable to work on behalf of the naval stores project, they

\footnotetext{
${ }^{36} \mathrm{Ibid}, 653-654$.

${ }^{37}$ Robert Livingston to Alida Livingston, October 21, 1710.
} 
nonetheless required food and shelter. A study of the adult male refugees reveals that most had worked as "husbandmen and vine dressers" and the remaining in various occupations from "schoolmasters" to "surgeons." Conspicuously absent among the agrarian refugees was a knowledge of tar making.

In exchange for their labor, the Palatines were promised "lands to the proportion or amount of 40 acres to each person free of all taxes, quit rents or other manner of services for seven years." ${ }^{39}$ Under the terms of the contract made with Hunter, the refugees would serve as the equivalent of indentured servants until their passage and provisions were paid for. Upon arrival, each would receive a livable tract of land that possessed few of the attributes promised by the governor, the lots being "about forty feet in front and fifty feet in depth . . . The huts were made of rough logs, the cracks plastered with mud _.." Upon arrival at Livingston Manor, even the most desperate refugees could not have missed the disparity between the golden promises of life in America and the harsh reality of their new future at the Manor. Their hopes for a new future lay in New York's naval stores project; their survival in the hands of the lady of the manor, Alida Livingston. ${ }^{40}$

${ }^{38}$ Ecclesiastical Records, 1824.

${ }^{39}$ Ibid, 1814.

${ }^{40}$ Walter Allen Knittle, Early Eighteenth Century Palatine Emigration: A British Governor Redemption Project to Manufacture Naval Stores (Baltimore: Geneaological Publishing Co., 1997),160. 


\section{CHAPTER THREE}

ALIDA AND THE PALATINES

". . . a noble and most beneficent success would have been achieved, had the effort been properly supported." ${ }^{1}$-Sanford Hoadley Cobb

In late 1700, Robert and Alida Livingston realized the fulfillment of a dream - the completion of a home on Livingston Manor. A motley group of tenants had inhabited the manor land for several years prior to the Livingston's move from Albany, but the renters' ability to flourish on an undeveloped piece of land, without easy access to supplies, had proven difficult. Upon completion, the Manor of Livingston became more than a manorial estate; it functioned as a "residence, trading post, fortress, meeting house and . . bakery." The couple could neither have imagined the financial trials that would await them at the Manor nor the hardships Alida Livingston would face as she endeavored to fulfill her husband's contract to provide for the Palatines. In Robert's absence, Alida bore the brunt of the work, and much of the blame, for the Palatine debacle that has darkened the family's name for generations.

One particularly troublesome year for the Livingstons, both financially and personally, was 1711 . The emigration of Palatine refugees to Livingston Manor in 1710 had presented an unprecedented opportunity for the family. Robert

${ }^{1}$ Sanford Hoadley Cobb, The Story of the Palatines: An Episode in Colonial History (New York \& London: G.P. Putnam's Sons, 1897), 201.

${ }^{2}$ Brandt, An American Aristocracy, 47. Prior to this time Alida resided in Albany and Robert spent most of his time - when not traveling abroad - in the couple's New York City home. 
Livingston contracted with Governor Robert Hunter to victual the German immigrants with his own resources, for which he would be reimbursed by Parliament. The couple also sold 6,000 acres of manorial property to the Crown for $£ 400$. The purpose of Palatine emigration to New York was to supply naval stores - pitch and tar - for the Crown, from the abundant forested property on the manor. Unfortunately for the Livingstons, in June of 1710 the Whig government, which had appointed Hunter, fell to the Tories, who saw no reason to honor Hunter's arrangements with Livingston. The stress of this venture reached its height in 1711 at the same time the Livingstons were confronted with their daughter-in-law, Mary Winthrop Livingston's, diagnosis of breast cancer. The cancer required surgical intervention and eventually took her life in 1713. Letters exchanged between Robert and Alida during their difficult years at the Manor illuminate their working relationship and depth of respect for each other's talents and entrepreneurial abilities. While Robert Livingston's participation in the Palatine venture has been the topic of much historical study, there is a significant gap in the study of Palatine immigration that only Alida Livingston can fill. It was she who negotiated with suppliers, dealt with Palatine families on a daily basis at the manor store and was left to answer to local creditors when Parliament refused to reimburse her husband's expenditures. ${ }^{3}$

3 Robert and Alida Livingston's letters for the year 1711 begin in July and continue through December. 
During the summer of 1711 , Alida labored to provide food and beer to the Palatines in addition to managing the farm's wheat production and other trading ventures. On July 10, she requested that Robert send her,

2 hogsheads tobacco 3 hogsheads rum 3 barrels of sugar Pepper ginger molasses 12 small vats English soap 3 dozen blue gloves (\&) stockings 2 dozen white men's stockings 4 pieces striped material 2 dozen choice stockings linen a dozen flowered skirts red and white thread sand (for scouring) ${ }^{4}$

These items were not only for family use, but also for sale to the manor's tenants. Alida instructed Robert, "Do bring that with you for otherwise I cannot get any money for now I have nothing that I can make a nickel on." The Livingstons counted on sales to manor tenants to supplement their income, which suffered because the royal government refused to pay for the stores provided to the Palatines. Alida's frustration is evident in her letter to Robert on July $16^{\text {th }}$, when she noted that manor employees were in the process of cutting wheat, and she was forced to "bake at night" due to the extreme July heat. Almost a week had passed since her last correspondence, and Alida complained, “I don't have a grain of sugar nor molasses nor rum in the house." In addition to the couple's scarce business stores, their personal supplies had also begun to run low.

Robert's reply on July 21, 171,1 was not encouraging. "I have read your 3 letters and can reply little for comfort, merely the melancholy news that there is no money for us here because of all that we have advanced for the Palatines...it is high time to stop baking." Robert's request placed Alida in an unenviable

\footnotetext{
4 Alida Livingston to Robert Livingston, 10 July 1711.

${ }^{5}$ Alida Livingston to Robert Livingston, 10 July 1711; 16 July 1711.
} 
position. If she continued to bake bread for the Palatines, the couple's financial resources would suffer. If she stopped baking, she feared a Palatine revolt. In the same letter, Robert warned, "They are vicious people, everyone says. All my fear is that they will beat the cattle to death . . . one has to be very careful." However, this fear was not so great as to convince Livingston to continue to provide supplies, for he claimed, "I cannot ruin myself for another." In a letter to Robert dated the same day, Alida continued to plead for supplies and noted with relief, "we now have good weather to harvest our wheat." Two days later, Robert wrote that "neither money nor anything for the bread and beer for the Palatines is obtainable here." Unfortunately, Robert also shared the news that many of the male refugees had joined with the local militia on an expedition to Canada during the War of the Spanish Succession and would now "leave their women and children without bread...that is hard." Despite this hardship, Robert reiterated, "don't supply any more bread, however things may be going."6

In the summer of 1711 , Alida's confidence in the Palatine adventure was at an all-time low. Her letters indicate a growing dissatisfaction with everyone involved in the escapade, including the governor, who had paid "little for the land" with the promise that the couple's "gain would be a lot." She expressed "sadness that you [Robert] do not get your money as per your agreement." Two days later, her frustration was evident as she stated, "I do wish that the Palatines had never

${ }^{6}$ Robert to Alida Livingston, 21 July 1711; Alida to Robert Livingston, 21 July 1711; Robert to Alida Livingston, 23 July 1711. 
come here.." Alida had every reason to be concerned about the Palatines on Livingston Manor.

The settlers, hired to produce naval stores for England, mistakenly believed that land in the fertile Schoharie Valley of New York was theirs by right of a 1710 agreement with Mohawk representatives they had met in England. The drudgery of producing pitch and tar at the Manor, coupled with their dependence on the mercies of the governor for food and supplies, caused them to react in an increasingly aggressive manner toward their taskmasters when they failed to receive the promised property. The Palatines, mostly farmers, did not respond well to tar-making. A lack of food, hard labor and broken promises reduced the Palatines to near despair. In June of 1711, Governor Robert Hunter confronted rebelling Palatines at Livingston Manor and used troops to bring them into submission. Hunter stripped the Palatines of their weapons and reduced them to the status of mere prisoners. The revolt, in addition to the Livingston's financial worries, prompted Alida to confront her husband with the ominous consequences of their situation. "You should try to get as many bills to pay your debt in England and accord with the governor for half money and half goods. Otherwise, if we stop, we have lost everything." 8

${ }^{7}$ Alida Livingston to Robert Livingston, 25 July 1711; 27 July 1711.

${ }^{8}$ Lustig, Robert Hunter, pp. 88-90.; Mr. Cast to Gov. Hunter, March 27, 1711 in Doc Hist, III., pp. 658-659; Alida to Robert Livingston, 27 August 1711. In his letter to the governor, Jean Cast shares a conversation he has had with 5 Palatine men. "They all agreed, that the selection of the Levingston lands was well planned...But the desire to possess a good deal of land upset and demolished... all these conveniences." Though the Palatines agreed that they were physically safe on the "Levingston lands" and that the property provided adequately for the naval stores program, dependence on the Livingston's supply lines, which were often cut due to a lack of financial resources, 
Pressure on the Livingston matriarch was increasing, as manorial tenants and Palatines alike continued to plead for food and supplies. And Alida had sufficient cause to worry. Jean Cast, often referred to by Alida as "Kas," was a local Frenchman and assistant deputy commissary to the Palatines. It was he who supervised baking for the refugees and references to Cast appear often throughout the couple's correspondence. Alida informed her husband on July $31,171,1$ that, "the workers and the cooper they torment me they say they can not live this way without beer and bread and can not get work and have no milk. . . if I had not hidden Kas they would have torn him to pieces on Sunday." ${ }^{9}$ The German immigrants, tired, hungry and enraged, believed that Jean Cast had misrepresented the terms of their contract. The Palatines sailed for America with the belief that they would receive forty acres immediately upon arrival and after seven years would repay the Queen with "hemp, masts, tar and pitch." Cast, who was also responsible for acquiring provisions, became the victim of their rage.

Alida's protection of Jean Cast is remarkable in light of his treatment of her husband. In a letter to Governor Robert Hunter, dated July 13, 1711, Cast conveyed the news to Hunter that "since the reconstruction of our Board, I have

caused a constant strain on both the immigrants and the Livingstons. A number of Palatine families moved to the Schoarie Valley and purchased land from the Native Americans, for which they received no formal patent. For information on the Palatines in New York, see Proceedings of the New York State Historical Association (New York: New York State Historical Association, 1904). Page 21 discusses the purchase of Indian lands by the Palatines.

${ }^{9}$ Alida to Robert Livingston, 31 July 1711; Mr. Cast to Governor Hunter, 13 July 1711 in Doc Hist III, 672; Alida Livingston to Robert Livingston, 4 November 1711 and 9 November 1711; Lustig, Robert Hunter, 86. 
found that his [Robert Livingston's] design has ever been to obtain the management of all the supplies for the People, and had I not had the foresight to demand a declaration from the general commission he would have seized it altogether." Only a few months earlier, Cast had reported to Hunter that the meat being supplied to the Palatines was of extremely poor - and unacceptable - quality. "I never saw salted meat so poor nor packed with so much salt as this pork was. In truth, almost one eighth of it was salt." In later correspondence, Alida vented her wrath toward "Kas" by referring to him as a "big rascal" and a "bad sneak," and informed Robert, "I can no longer stand Kas that he wrote such lies about you." Alida presumably found out Cast's lies when he brought her "a letter from the governor" which she forwarded to Robert.

Cast also recounted to the governor a bet made with Robert Livingston regarding the inaccurate weight of flour barrels. The barrels, which Cast argued were heavier than standard barrels and thus distorted the amount of flour contained inside, were in truth of the wrong size. Cast informed the Governor he had taken measures "to investigate the cheat." ${ }^{10}$ Hunter undoubtedly shared this information with Robert, earning Alida's disfavor. A year later, Alida's confrontations with Cast continued. "After you left Mr. Kas arrives and called you

${ }^{10}$ Mr. Cast to Governor Hunter, May 1, 1711 in Doc Hist III, pp. 659-660; Alida Livingston to Robert Livingston, 24 April 1712; Alida to Robert Livingston, 29 April 1712. "Kernel bread" was cornbread, which was not part of the Livingston's victualing contract, though Alida notes, "the people do want to take it but they will not allow it." Alida's reference to "they" presumably refers to Cast and his associates, but no specific names are mentioned. Another letter from Alida to Robert, dated 25 July 1711 notes another issue with bread and beer measures at the manor. Alida notes that much of the beer had been consumed prior to weighing, and that "they had been put up to that by some officers." 
a swindler, that you baked kernel bread and distributed it without his order ... he will not have his people take it ... I believe Kas also eats on his own so we will be rid of him." Less than a week later, the rift was temporarily mended. "I have written you that Mr. Kas has been in such a rage but now has come to himself and comes and eats again." Not only did Alida have to bear Cast's disdain toward her husband, she had to bear his regular attendance at her table. She also dreaded the future if Parliament did not make good on the couple's debts, noting "he [Hunter] will pay us off otherwise we will be in worse shape than before." ${ }^{11}$

The ongoing problems did not appear to have the same effect on Robert, who noted in a letter dated May 2, 1712, "In case Cast is angry . . Nobody cares about that here ... they can read him like a book already." Four months later, Robert noted about Cast, "should he have anything worth while, he would love to blab ... [one] freely believes he is a spy." Robert hastened to reassure his wife that despite their losses, the Governor had every intention of helping them to pay their debts. "And he [the governor] promised that, come what may he would see that I would be paid, even if his wife and children would suffer want."12

Alida's letters during this time portray her anxiety at both the Palatines and the Livingston situations. The couple was unable to secure steady payments for

${ }^{11}$ Alida Livingston to Robert Livingston, 27 July 1711; Robert Livingston to Alida Livingston 22 August 1712. On 5 November 1711 Alida writes to Robert, "I am so sad that the governor has written you such a letter which we do not deserve from his hand." The relationship between Livingston and Governor Hunter was often in flux.

${ }^{12}$ Robert Livingston to Alida Livingston, 22 August 1712. Robert's assertion that Cast is a spy is almost as unrealistic as his belief that the Governor would pay him at peril to his own family. 
the food they provided, and in May of 1712 Alida informed Robert, "I am very sad that the bills have not been paid and that I hear that the governor does not give you any other bills to satisfy the merchants in England and that you can not send any money up to buy wheat. I have great difficulties here." When the Palatine men left for their Canadian expedition, Alida had to provide for their families. "There is a great crying among the wives and children that their men have gone and [they] have no bread or beer. I say I can not help it they say they quite know it they see without money they cannot bake."13 Many refugees-turned-soldiers returned from Canada to find their wives and children near starvation, "no provision having been given them during their absence." This was not the first time the refugee children, and their families, had suffered loss. A number of Palatine offspring had either come to New York as refugees or been born into the camps during the first years of settlement. In June of 1710, the New York council presented "An Order for Apprenticing the Palatine Children." Under the terms of the agreement, the council accepted,

Proposalls for Placeing out the Orphans and other Children whose Parents have a numerous ffamily Entring into an Instrument in Writing to Cloath Victuall and use them well and to deliver them to the Government when called for. It is ordered than an Advertisement be printed Signifying that his Excellency is willing to Dispose of Such Orphans and other children ... ${ }^{14}$

${ }^{13}$ Alida to Robert Livingston, 28 May 1712; Alida to Robert Livingston, 7 August 1711. On 21 July 1711, Robert informed Alida, "The Governor has left, otherwise would tell him of the danger to let the people now do without bread just as the men are to leave for Canada." This proved to be a wise prediction, as military assistance was needed on the manor in 1711 to guard against a Palatine revolt. 334.

${ }^{14}$ An Order for Apprenticing the Palatine Children, 20 June 1710, Doc Hist III, 
In addition to poor supplies and broken promises, a number of Palatine families lost their children to local families or tradesmen. The further indignity of serving on behalf of the colony while their wives and children starved was unacceptable to Palatine husbands and fathers. Alida's recanting of the Palatine's plight was indeed accurate. A later rendering of the naval stores venture written by the Palatines states,

there being no provision to be had, and the people bare of Cloaths, which occasioned a terrible Consternation amongst them, and particularly from the women and Children the most pityfull and dolorous Cryes and lamentations that have perhaps ever been heard $\ldots{ }^{15}$

Robert Livingston's decisions regarding the provisioning of the Palatines were purely financial and usually made during his absences from the Manor. For Alida, the day-to-day plight of the wretched Palatines could not be ignored. Robert Hunter, who assumed supervision of the Palatines in good faith, was left without reimbursement for the venture when the Tories returned to power in England, leaving Hunter, Livingston - and more importantly, the Palatines without financial backing from Parliament. The resulting chaos required Hunter to station troops at Livingston Manor to achieve order. Though the couple's methods in providing provisions to the Palatines has been the topic of much

${ }^{15}$ Philip Otterness, Becoming German: The 1709 Palatine Immigration to New York (Ithaca: Cornell University Press, 2004), 108, 112; The Conditions Grievances and Oppressions of the Germans, Rd. August 20, 1722, Doc Hist III, pp.707-714; 682; Ibid, The Commissioners of the Palatines to Col. Ingoldesby, 2 May 1712. As Hunter became more desperate for cash, he pursued ways of relieving himself of the burden of providing for the Palatine children. Ironically, Philip Otterness notes, "Only the pine knots gathered by the immigrant children- the children whom Hunter had hoped to apprentice rather than feed - produced a tangible result. The few barrels of tar resulting from the children's labor constituted the total yield of Hunter's grand scheme." 
historical debate, in reality, the ongoing lack of financial reimbursement put the Livingstons in an unenviable position. The contract with Hunter required them to victual the Palatines, and without a clear assurance of repayment. ${ }^{16}$

In 1712 Parliament declared an abrupt end to the naval stores project. The difficulty of controlling Palatine revolts, inefficient management and political changes in England left Parliament, and the Livingstons, in a precarious position. During the winter of 1712 an ice pack amassed behind a bridge built by the Palatines at Livingston Manor. When the bridge gave way, the manor's flour and saw mills were destroyed. The expense of rebuilding, added to the cost of shipping wheat via boat more than twenty miles down river for milling, further devastated the Livingston's finances. The sawmill supported the building and maintenance of storage houses for the family's victualing supplies, bridges built over the manor's primary water supply, Roeloff Jansen's Kill, and necessary repairs and additions to the brew house, bakery and store. Alida's letters did not mention the bridge collapse specifically, but in the spring of 1712 she informed Robert, "the carpenters are now working lustily," noting a week later, "the dam has been stopped." A month later, she lamented, "This is now the second time with 120 bushel to have milled at Barent's . . I I hope that it will now nearly be done ... that we shall mill ourselves." The twenty-eight mile trip to mill the Livingstons' flour, a trip made via canoe, took its toll on Alida. On May 28, 1712

\footnotetext{
${ }^{16}$ Arrival of Troops at Livingston Manor, 9 May 1712, Doc Hist III, 682.
} 
she complains, "the canoes have been gone for four days this is the fifth day and still not here..17

The Livingstons hoped for an extension of the Palatine project in order to claim their debts, but met with continued resistance. In May of 1712, Robert's plea to England ended in disappointment. "The Lord Treasurer . . . is not willing by any means to accept the bills of the Palatines, which we had." In a letter dated November 8, 1712, Robert wrote Alida that although the Lords of Trade had suggested a continuation of the naval stores program, "no answer to all the representations nor money comes here; we have knocked on a deaf man's door." ${ }^{\text {18 }}$ This was certainly a discouraging comment for Alida, who that spring had informed her husband, "I am very tired of this kind of life." Even cleaning supplies were not available at the manor that spring, and Alida requested "a whitewash brush ... wheelbarrow and some black-lead . . . a bottle linseed oil we cannot clean the house without those things." ${ }^{19}$ A leaking kettle in the manor's brewery, a lack of salt and "the sad news that the bills of the Palatines are not paid" imposed further strain on Alida, who was growing tired of the constant stress. In 128 May 1712 .

${ }^{18}$ Robert Livingston to Alida Livingston, 8 May 1712; 8 November 1712. Despite the couple's difficulties in procuring reimbursement for the Palatine venture, they continued to conduct trade as usual. Alida's letter of 10 November 1712 included a laundry list of items that she had sent to New York City, including "80 barrels of beer . . . flour . . . 13 bushel peas, 7 ducks . . . deer." The Livingstons paid for the Palatine supplies from their own financial resources, with the expectation that they would be reimbursed in cash.

${ }^{19}$ Alida used no punctuation of any kind in any of her letters. I have tried to retain the natural flow of her letters wherever possible, using punctuation only where it is absolutely necessary. 
the pre-refrigeration era, a lack of salt meant that meat could not be cured, and Alida would have to deal with the consequences in Robert's absence. In May of 1712 she wrote, "I long to have you home ... [signed] your sad wife."20

The Livingstons continued to wait for the reimbursement due them for the Palatine contract. In addition, a boundary dispute emerged between Alida's husband and neighbor Henry Van Rensselaer over the boundaries of Livingston Manor. A 1704 grant of Claverack, the southern portion of Rennselaerswyck, to Henry Van Rensselaer created friction between the two families, when in 1713 Van Rennselaer claimed his grant included the northern part of Livingston Manor. Livingston took full advantage of the situation and "agreed to arbitration," not as a conciliatory gesture but for his own devices. Robert, who hoped that the New York Assembly would agree to a reimbursement of his debts in the future, requested a "confirmatory patent" for the Manor. His request included "the Priviledge that the ffreeholders of said Manor may elect and Return one Deputy or Representative to sit in the Genll Assembly to Represent the ffreeholders and inhabitants of the same."21 As Lord of the Manor, Robert's election to the Assembly was almost guaranteed. As a result, he would be able to speak in the Assembly on his own behalf. This was particularly important as Alida informed

${ }^{20}$ Alida Livingston to Robert Livingston, 28 May 1712.

${ }^{21}$ Leder, Robert Livingston, pp. 230-231, 236-237; Doc Hist III, 685-686; Biemer, Women and Property, 70. For more information on the boundary dispute between the Livingstons and Van Rensselaers, see Julius Goebel Jr. and Joseph H. Smith, eds., The Law Practice of Alexander Hamilton: Documents and Commentary Volume III (New York: Columbia University Press, 1980), Chapter 4, "Claverack." 
him, "there are several in the assembly who are against you." ${ }^{22}$ In regard to Van Rennselaer's claim, Alida wrote, "If you can come to an agreement with Henry without too much damage then do so."23 Unfortunately, despite Alida's "hope that God will give us that they pay us what is our due as much as anyone else," the couple was to be disappointed. ${ }^{24}$

On April 21, 1714 Robert reported, "The Assembly [men] have rejected a lot of my warrants." On May $10^{\text {th }}$, he continues to describe his financial woes,

I am still employed in soliciting the Assembly for the payment of my warrant ... [I] have given to the House a memorandum-book about my salary, but [it] has not been read yet, since they were [working] at the Governor's account then, which they have allowed except 6 sh., namely $£ 4,122$-, so that I hope the Governor will have no pretext any more that He doesn't have money. ${ }^{25}$

Governor Hunter, allotted funds by the Assembly for the colony, could not use them for Livingston's debts. He did, however, address the Livingston-Van Rennselaer patent dispute that the Assembly had ignored for several years in addition to helping the Livingstons in other areas. "The Governor says I am

${ }^{22}$ Alida Livingston to Robert Livingston, 22 April 22 1714. Alida's information was, as usual, accurate and to the point. Robert was, indeed, disliked by many in the assembly, who claimed he was seeking more reimbursement than he deserved. Robert was certainly not surprised by this animosity, as he wrote Alida on 17 April 1714, "I have written to you, how things are going in the Assembly; as bad as ever one can bear." The Livingstons struggle for reimbursement became quite personal, and Robert reported on 19 May 1714 that he had, "nobody here to help, and all friends are against us."

${ }^{23}$ Alida Livingston to Robert Livingston, 17 April 1714. The comment regarding "Henry" appears in the letter's post script.

${ }^{24}$ Alida Livingston to Robert Livingston, 15 May 1714.

${ }^{25}$ Robert Livingston to Alida Livingston, 21 April 1714; 10 May 1714. 
allowed to settle as many Palatines as I want; he will not hinder it, and will send up board to support the people." Though Robert was obviously pleased with the decision, his comment to Alida about the Governor himself was less congenial. "But he [the governor] would like to board with us ... Never in all his life will anybody, who spends [my] money, come to my table again. He may be with the doctor or dominie....26 Robert was more than willing to permanently settle Palatines on his land, but inviting the Governor to be a houseguest was another issue. Robert Livingston knew which friends to keep close, however. His perception most likely changed after the Governor intervened in the LivingstonVan Rennselaer patent dispute, which was of particular concern to Alida Livingston. First, because the Manor's geographic location placed it in two counties, Dutchess and Albany. The political and administrative confusion engendered by the Manor's location was an ongoing headache for the Livingstons. ${ }^{27}$

In April of 1714, Alida informed Robert, "I hope that you will receive a new patent ... it is too far out of the way for them [the tenants] and to pay tax in 2 places is very sad. ${ }^{28}$ Alida was also concerned about the property that the Livingstons had provided for the Palatines' use, and urged her husband to make sure "that the lands may be returned to us which the Palatines have from the

${ }^{26}$ Robert Livingston to Alida Livingston, 10 May 1714.

${ }^{27}$ Leder, Robert Livingston, 237. Under Livingston's original patent, 1686, "freeholders were authorized to elect their own assessors and collectors." This obviously caused stress in Albany, where authorities wanted the right to to use their own people for the job.

${ }^{28}$ Alida Livingston to Robert Livingston, 17 April 1714. 
queen and that they do not continue ... they have spoiled so many thousands of trees." She added, "do try to get some land now while this governor is here and to extent [sic] your patent." ${ }^{29}$ Alida hoped that Governor Robert Hunter would repay her husband with favors, if not hard cash. Land equaled financial security, and the home government's refusal to repay the Livingston's debts prompted Alida to seek reimbursement in other forms. The Livingstons retained use, if not ownership, of the 6,000 acres until 1724 , when Palatines residing on the property requested that it be granted to them and their heirs. Having settled on the property and improved it, they believed ownership should fall to their families. Surprisingly, so the did the New York council, which permitted " . . Jacob Sharpe Johannes Heiner Johannes Kolman \& Christophel Hagendorn their heirs and assigns" the same lands that Alida had requested Robert to regain for Livingston Manor. ${ }^{30}$

Despite this setback, the Livingstons were fortunate. In October of 1715 , Governor Hunter ordered his attorney general to draft a new patent for Livingston Manor. The document confirmed the Livingston's original patent of 1686 and provided for a new survey to be taken of the manor's property. The original patent, which included 2600 acres, expanded to approximately 160,000 acres in

${ }^{29}$ Alida Livingston to Robert Livingston, 19 May 1714. "extent" appears to be a typographical error in the translations.

${ }^{30}$ Petition of Jacob Sharpe etc. In Behalf Of the Palatines In The Manor Of Livingston, 13 June 1724; Order of Council Thereupon, 13 June 1724; Report In Favor Of Issuing Letters To The Palatines Of Germantown, 7 August 1724, Doc Hist III,. 430435. The loss of such a large tract of land surely upset the Livingstons, particularly as the land went to the Palatines with whom they associated much of their misfortune during their years at the manor. 
the 1715 survey. Lawrence Leder refers to the new patent as "one of the grossest land frauds ever perpetrated in an age noted for unethical dealings. ${ }^{31}$ It certainly appeared suspicious that the Lord of the Manor excused Robert Hunter from paying his outstanding Palatine debts to the Livingstons that same year. Hunter's favors also included the addition of, "two constables," the right of freeholders to choose assessors and collectors, and granted these same freeholders the right of "meeting, electing, choosing and sending one fitt person . . . to be their representative." Alida was to be disappointed, however, as the new patent excluded the 6,000 acres sold to Queen Anne for the Palatine venture. A note following the patent clarifies this exception, however. "That 6000 acres ... was sold by Robert Livingston, it yet remained a part of the Mannor... and tho' the Grant of the Soil of those 6000 acres is excepted, they are nevertheless included and made part of the Mannor as much as any other part of it is." ${ }^{32}$ Though the Livingstons did not technically retain ownership of the Palatine lands, they were able to include them as part of the manor and therefore benefited, at least temporarily, from their settlement. The Palatines were, after all, rent and tax paying tenants.

It is easy to fault Alida Livingston for her shoddy treatment of the German refugees. Her provisioning of the Palatines, which included insufficient supplies

${ }^{31}$ Leder, Robert Livinsgton, 35; Kim, Landord and Tenant, 39-40; French, JH. Gazetteer of the State of New York (Syracuse: R. Pearsall Smith, 1860),. 247-248. Livingston's property seemed to extend itself as if by magic.

${ }^{32}$ Governor Hunter's Patent 1715, in Doc Hist III, 696 and postscript; Leder, 242-243; Lustig, Robert Hunter, 144. Livingston Manor became a part of Albany County, a more advantageous association than Dutchess County. 
and subpar meats and breads, is certainly not admirable. It is doubtful, however, that any other family in Albany would have fared better. The colony's refusal to pay for the beer and bread as promised resulted in serious financial ramifications for the Livingstons that lasted for years. As the couple's expenditures increased, they increasingly turned to local creditors and suppliers for assistance with the reassurance that Governor Hunter would eventually repay their debts. When the Palatine project ended in 1712 the Livingstons' inability to make good on their debts became a constant source of frustration for Alida. Robert's dependence on his wife's managerial skills increased exponentially during the following years as the couple strove to repay their debts from the manor's trade. The ill fated choice to provision the Palatines had been Robert's; the responsibility for surviving the financial chaos that ensued would fall to Alida. 


\section{CHAPTER 4:}

THE MANOR YEARS: SURVIVAL

The year 1712 marked a turning point for Alida Livingston. The dissolution of the Palatine contract that year left the Livingstons in dire financial straits. The permanent settlement of refugees on manorial property was, in fact, the only benefit realized by the Livingstons from the Palatine escapade. Though the couple owned property in New York City and a profitable trading business, they could not purchase or trade goods without hard cash or credit. Though Robert petitioned the colonial assembly continually for reimbursement, the government repeatedly denied his requests. In order to maintain the Livingston name, and fortune, Alida increased the manor's production of flour and other commodities. It is due to her management of the manor's various industries that the Livingston fortune survived, and prospered, during and after the Palatine settlement.

The settlement of Palatine families as tenants was providential. The Palatines at the manor and their acquaintances in four other Palatine villages shopped regularly at the manor's store, which bolstered the Livingstons' struggling finances. Robert shipped items from New York City to the manor for sale, not only to tenants but also to other local families. In September of 1711, he sent a particularly large shipment and indicated, "It's good merchandise and well purchased; and you can sell it cheaply to attract the retail trade and let Claverack and Kinderhook and the Flats know that you have all kinds of goods and will give a better bargain than at Albany." When Palatine supplier "Mr. Clerk" requested that Robert purchase "30 or 40 fat beasts ... for the Palatines" Robert instructed 
Alida to send third son Gilbert, " . . to all the farmers, therefore, to buy 50 fat beasts ... and make him take a list with him of what kind of goods we have; that will certainly be money." ${ }^{33}$ That winter Robert resided at the manor and helped Alida to manage the tenants, about thirty-three in all. By the following year, the Livingston account books show that approximately fifty percent of the local debts owed to the Livingstons were for goods purchased by their own tenants, a shift from previous years. ${ }^{34}$ In Robert's account ledger, columns of names line pages titled, "Palatine Debtors who live in the Mannor of Livingston." As Palatine debts to the Livingstons increased, the couple was able to isolate more of their local trade to the manor's inhabitants, which saved them the trouble of shipping so many goods via "canoo" or "yacht" to other local communities. ${ }^{35}$ Unfortunately, the Palatines did not always pay their debts in a timely manner which resulted in increasing frustration for Robert. Alida, known for her savvy business skills, surprisingly sympathized with the Palatines' plight, for which she received a sound - and very rare - scolding from Robert in May of 1713: "As regards the

${ }^{33}$ Robert Livingston to Alida Livingston, 15 September 1711. Two letters, each dated 29 September 1711, note Alida's response. Gilbert managed to purchase 40 of the requested animals and Alida apparently sent him immediately back out to complete the job. "We have about 40 animals...I have sent Gijsbert out to get a good 10 more..."

${ }^{34}$ Kierner, Traders and Gentlefoks, 42-44; List of Debtors Drawn out of Ledger F, Reels 3 and 4 of the Livingston-Redmond MSS.

35 "Palatine Debtors who Live in the Mannor of Livingston." Livingston-Redmond MSS, Reel 4; Kierner, 43-44. The list of debtors, which begins in the year 1719, does not include a specific list of items purchased by the Palatine tenants. Because these were Palatines who actually lived on the manor, and not in one of the four local Palatine communities, it is reasonable to assume that these purchases were for basic supplies from the manor store as well as flour and beer. It must be noted that Kierner claims that at least 48 Palatine families settled on the manor at the end of the naval stores program in 1712 , but cites a list of Palatine debtors dated 1726. 
Palatines: it has been told to you a thousand times, that they are rascals, and that you must not give them credit, for they are worse than northern savages . . . therefore, give credit to none, even if they would ever complain so much, that they do not have bread. They are liars and impostors, and we must have patience now." ${ }^{36}$

Oversight of the manor store, and Palatine accounts, was only one aspect of Alida's numerous responsibilities. The manor's brewery was integral to the Livingston's economic survival, as beer was one of the British colonists' most sought after commodities. Though the substantial consumption of beer in the colonies was partially due to unhealthy water, the sale of beer quickly became an integral and lasting part of New York's trade, both within and without the colony. Unfortunately, inebriation also became a frustration for colonial officials. As early as 1644, Governor Wilhelm Krieft imposed beer taxes on the residents of the New Netherlands, the first tax of its kind in the New World. Later, in an attempt to quell the growing tide of alcoholism and misconduct, Director General Peter Stuyvesant prohibited the sale of beer on the Lord's Day. Inhabitants, enamored with the fur trade and production of beer, were forbidden to export "bread-corn" in $1653^{37}$, and a law of 1662 forbade citizens to pawn personal items to buy beer. Breweries were established early in the Albany area, where the Livingstons

${ }^{36}$ Robert Livingston to Alida Livingston, May 1713. According to historian Clare Brandt, Robert passed down his attitude toward the Palatine tenants to his heirs. "They, and their children, and their children's children, grew up equating Palatine with parasite... It is an attitude that appears over and over, in generation after generation of the family, and exists even to the present day." Brandt, An American Aristocracy, 66.

37 J. Leander Bishop, ed., A History of American Manufactures, Volume I (New York, A. M. Kelley, 1966), 256-257. 
resided. Kiliaen van Rensselaer established a brewery at Rensselaerswyck in 1637 and the famous Rutgers brewing family opened their first brewery in Albany in 1649. When the Livingstons began to build their home on the manor in 1699 , the manor's access to a large supply of water made it a perfect spot for a brewery, as did the area's cooler climate. Though many poorer families chose to brew at home, there was an almost constant demand for beer in early New York. While home brewers often used corn or barley, those of the "richer sort generally brew(ed) their small beer with malt," as did the Livingstons. When the English assumed control of the New Netherlands during the Second Anglo-Dutch War, there was "one brew house or tavern for every 160 people" in the colony. ${ }^{38}$ For an enterprising couple like the Livingstons, this provided an opportunity not to be missed.

Alida managed the manor's brewery and frequently mentioned brewing problems in her letters. Though Alida had assistance, she maintained close scrutiny of the brewing process and was responsible for the ordering of supplies and the hiring and oversight of the brewery's workers. In the fall of 1711, she lamented, "I have hired the brewer till May but have had to hire a Palatine with him." ${ }^{39}$ Alida could not afford to be careless in the hiring of a brewer as

${ }^{38}$ Ibid, pp. 251-254; Gregg Smith, Beer in America: The Early Years - 1587-1840 (Boulder: Siris Books, 1998), 227; 50, 184-188, 191. Bishop discusses the first paved street in New York, which had to be covered with cobblestones due to the amount of water pouring into the streets from local breweries. The street was aptly named "Stone Street." (see 275)

${ }^{39}$ Alida Livingston to Robert Livingston, 29 October 1711. On 2 April 1713 Alida requested that Robert send "hops" and noted that she would send someone to "fetch coal for brewing." The Livingstons had to make the most of every opportunity to brew, 
distillation was a hazardous undertaking. Colonists, unaware of the dangers of carbon dioxide produced during the brewing process, could die if they did not have access to proper ventilation. Brewing was also an expensive operation and a batch of "bad" beer could cost a brewer a great deal, both in pay to employees and wasted grain. ${ }^{40}$ In the summer of 1711 Robert commented, "The people all complain that the beer was no good; and [to that] from which I thought to get money I have to give reduction, because it was so bad. A lot of difficulty I have with it." ${ }^{41}$ In the early 1700 s, most large breweries possessed a "brew kettle of about 20 barrels and a horse-powered mill . . pumps, mash tun, forks, rakes, shovels and buckets ... made of wood." By the early eighteenth century some brewers had turned from wood kettles to more expensive, yet more durable, "coppers." ${ }^{42}$ The Livingstons brewed using the new coppers, as evident in Alida's letter of October 29, 1711. "Our kettle has a bad leak it nearly does not make sense to brew this way I think that it can be patched allright as it stands there to rest on heavy beams as it is being patched ..." She instructed Robert, "

and there was no guarantee that when wheat was plentiful, the other supplies necessary for brewing would also be available.

${ }^{40}$ In the Duke's Laws of 1664, James, Duke of York, permitted brewers who provided inadequate beer to ships to be taken to court and forced to pay damages. In 1676 grain distillation was briefly prohibited in New York in an effort to refocus the attention of New Yorkers on the growing of grain for food. Bishop, A History of American Manufactures, 256-257.

${ }^{41}$ Robert Livingston to Alida Livingston, 23 July 1711. Robert did not define who "the people" were. He may have been referring to the Palatines, as he would have lost money if their beer was rejected for insufficient quality and had to be supplied for a second time.

${ }^{42}$ Smith, Beer in America, 255. 
... let the coppersmith come." The problem was not corrected by November 1 , when Alida reported, "we have only done 7 brewings ... there is a hole now that we can't get closed." While the use of copper was preferred for brewing, it was much more difficult and expensive to repair than the wood used by many home brewers. Alida's problems with the copper kettle was obviously a constant, as in the spring of 1712 she again complained, "The brewer ... says the bottom of the kettle is going to have a leak again has only brewed 6 weeks with that.." ${ }^{43}$ Unfortunately, at that time the Livingstons did not have enough grain to mill for any purpose, causing Alida to grumble, "If we could get grain we could get out of debt." The attainment of grain was difficult and the couple frequently shifted supplies between the bakery and the brewery in order to receive the most profit. In the summer of 1711 Robert advised, "And that you are carrying on with baking can be of no help, for we can't do it for long. Therefore, should some wheat be left, it will be good to brew heavy beer, which would mean ready money here if it would be brewed well . .."44 A few days later, Alida reported with relief that "the kettle has been patched" and "we have now about 250 bushel malt." ${ }^{\text {"5 }}$ An abundance of grain did not always equal prosperity for the manor's brewery, however. In April of 1713, Robert advised Alida to "Let the malting and brewing

${ }^{43}$ Alida Livingston to Robert Livingston, 20 October 1711; 1 November 1711; 14 May 1712.

${ }^{44}$ Robert Livingston to Alida Livingston, 31 July 1711.

${ }^{45}$ Alida Livingston to Robert Livingston, 5 November 1711; 9 November 1711. In addition to Alida's frustration regarding the lack of grain, the Livingstons' slaves had escaped and the Livingstons sent local Indians to apprehend them before they crossed the border into Canada. 
be stopped immediately, and have all the corn bolted . . . [l] will have a lot of trouble with selling this beer." ${ }^{46}$ Because of an unexplained malting problem, the Livingston's beer was "disliked so much, that it refuses to be sold; and what I will do with it, I don't know ... There's so much good beer coming from the Sopus, and so good, that ours is no match for it. What is wrong with it, I don't know . . . The beer worries me very much.." ${ }^{47}$ Alida surely shared his frustration, as low beer sales necessitated that the manor's gristmill, sawmill and bakery compensate for the loss of income.

The procurement of grain for the manor's bakery and gristmill was one of Alida's most pressing responsibilities during her husband's absences. During the Palatine settlement, the Livingstons had provided bread for the immigrants as well as the manor's tenants. And baking, like brewing, was a serious business in early New York. By 1664, the date of the first English conquest of the New Netherlands, it had become the "foremost merchant milling center in the colonies." ${ }^{48}$ The colony's first commercial bakery opened in 1645, and, unlike modern bakeries, operated under strict regulations. As early as 1656, bakers were required to follow "laws regulating the size, price and quality" of their

${ }^{46}$ Robert Livingston to Alida Livingston, 4 April 1713 . Bolting" refers to the sifting of corn for use as cornmeal or flour. Robert hoped to take advantage of flour prices as beer was not selling well in the city.

${ }^{47}$ Robert Livingston to Alida Livingston, 9 April 1713 from New York City. "Robert's reference to "sopus" is actually "Esopus," an area which referred to most of Ulster County, New York. 29.

${ }^{48}$ Herman Steen, Flour Milling in America (Westport: Greenwood Press, 1963), 
breads. ${ }^{49}$ Bread regulations varied according to the availability of supplies and the types of bread being baked. For example, "hard" or "ships bread" was the forerunner of hardtack, a concoction of flour and water that could be stored for some time without spoiling. ${ }^{50}$ Hard bread and corn bread were not as popular as white bread, which was evidenced in the complaints of the Palatine supervisors when the Livingstons baked "kernel bread" instead of their usual white loaves. The most common breads - white and "coarse" - appear regularly throughout the Livingston's letters. Strict prices were set for these breads, with the higher price going to white bread. For example, "Fourteen stuyvers for a double coarse loaf of eight pounds ... and eight stuyvers for a white loaf of two pounds." Bread quality was regulated by local officials and bakers were required to stamp their initials into each loaf. Historian Alice Morse Earle notes that the sale of other sugared breads and cakes by bakers was forbidden "unless he also had coarse bread for sale." Earle argues that these items were most likely seen as "extravagant" and may have led poor citizens to squander their money on sweets instead of daily staples. ${ }^{51}$

${ }^{49}$ William G. Panschar, Baking in America: Economic Development, Volume One (Illinois: Northwestern University Press, 1956), pp. 26-27. It should be noted that regulations on baking were present not only in New York, but in other quickly growing colonies such as Massachusetts.

50 Ibid, p. 27.

${ }^{51}$ Earle, Colonial Days in Old New York, 139. Earle's chapter on "The Dutch Larder" provides a wonderful look into the average Dutch household in colonial New York. Doughnuts, tea cakes and other sweets were much loved treats for the Dutch apparently so much so that some would squander money on sweets rather than necessities. 
The market for bread, then, was extremely high, particularly since the Livingston's tenants would have had difficulty procuring bread from Albany, given its distance from the manor. When weather and crops were good, the Livingstons were able to bake regularly - or mill flour - to supplement their trading income. However, when weather was bad or problems arose with the gristmill, the Livingston's finances were subsequently strained. Wheat was more than a necessary food staple to the farmers of New York. According to historian Sung Bok Kim, "mercantile success in no small degree depended on one's ability to command as large an amount of wheat as the market called for." The Livingstons relied on "wheat procurement agents" to aid in this business, and Alida frequently wrote of her own efforts to procure the wheat necessary to pay down the family's numerous debts. One way the Livingston's managed to maintain a constant supply was by insuring preemptive rights to their tenants' wheat. As early as 1708, Robert maintained a lease with Andrew Gardner, allowing him the "preemption of all the other corne grain flax hemp...over and above what shall be requisite for the support of his or their private family." ${ }^{52}$ The Livingstons agreed to pay market price for the grain, and both parties prospered. During the Palatine debacle, shortages of grain forced Alida to plead with Robert for "flour to bake for 2 months until grain comes." 53 The Palatines were prohibited from baking their own bread, which forced them into terrible

${ }^{52}$ Livingston-Redmond MSS, Reel 3; Kim, Landlord and Tenant, 231. The use of preemptive rights was typical on colonial manors. Kim notes that there were often discrepancies between manorial lords and their tenants in regard to preemptive rights, mainly in regard to fair market prices.

${ }^{53}$ Alida Livingston to Robert Livingston, 8 November 1711. 
circumstances. Prior to 1719, the Livingstons operated the only gristmill within 20 miles of the manor. The family added another prior to 1720 , affording them a further stronghold on their neighbors' milling. ${ }^{54}$ This was particularly important to the couple, as wheat and/or flour was often accepted as payment in lieu of cash in colonial New York, as was tobacco in Virginia and indigo in South Carolina. In April of 1725, Mr. Augustus Jay, to whom the Livingstons were indebted, offered the following settlement. "Inside is your account: the balance being in my favour . . . I desire you send me . . . money or good flour.".55

In May of 1712, Alida informed Robert that, "there is no wheat to be had here but at Klaverack which will not be much . . . we will send Uncle Staets wheat with the canoe and mill at Barent's ... we will make it till our mill works." ${ }^{56}$ The next day, she reported, "I will only get 400 bushel from all of Klaverack ... what is in the attic has mostly been used for malt." ${ }^{57}$ Because of the lack of grain on Livingston Manor, the couple had to purchase grain elsewhere. Klaverack, which

${ }^{54} \mathrm{Kim}$, Landlord and Tenant, pp. 158, 167. Kim notes that the building of a gristmill usually cost between $£ 700$ and $£ 800$, which he argues is probably why the couple did not build the mill earlier in their marriage.

55 Augustus Jay to Robert Livingston, New York, April $1725 . \quad$ LivingstonRedmond MSS, Reel 4. In a letter to Alida dated 4 June 1726 Robert wrote, "I hope that when you send down the 10 tons of four and cornel you will send the butter down as well, since I intend to pay Mr. Jay with butter for the iron and steel." Though the Livingstons frequently paid creditors with flour or other goods, they preferred to receive cash for their own debts.

${ }^{56}$ Alida Livingston to Robert Livingston, 8 May 1712.

${ }^{57}$ Alida Livingston to Robert Livingston, 9 May 1712. Klaverack, or "Claverack,"was part of Renssalaerswyck that became a point of contention between Robert Livingston and Henry Van Rennsalaer. The Livingstons were forced to purchase wheat for milling from other sources. 
bordered the Manor, was actually some distance away and grain had to be transported via canoe or "yacht." This was a problem for the Livingstons in the spring of 1714 , as Alida reported, "the farmers want our yacht to fetch the grain otherwise we will not get much from Klaverack ... we can not go and get it with the canoes for they have a leak." 58 This was frustrating for the Livingstons, as flour and grain sales regularly provided the family with hard cash in an economy where shortages of specie were common. ${ }^{59}$ Only one month before, Robert had reported, "I have sold the flour: 1 ton to Philip Cortlant for 18 sh. In silver money; 1 ton to Philip Shuyler (for) 18 sh. $9 \mathrm{~d}$ in silver money - I intend to send that up for wheat-debt; then there's $1 \frac{1}{1 / 2}$ tons to Freno for 19 sh. $6 \mathrm{~d}$. for debt, 4 small casks to Loyal for 1 barrel of gunpowder, [and] 4 small casks . . . for debt." ${ }^{, 60}$ One week later Robert sent the money to Alida with news that he had purchased, "such beautiful negroes as I have ever seen!" Robert instructed his wife, "do not sell them for less than $50 \mathrm{lb}$., please, for they are worth it." Another letter dated the same day, obviously a postscript, stated, "I have forgotten to write to you in my letter, that the flour is rising now and soon will be $21 \mathrm{sh}$. and even more. Therefore, make them bolt as soon as ever they can, for the negroes have to be

${ }^{58}$ Alida Livingston to Robert Livingston, 19 May 1714. The distance between Klaverack and the Manor would have been significant at the time, particularly when the amount of grain being transported was 400 bushels.

${ }^{59}$ Cathy D. Matson, Merchants \& Empire: Trading in Colonial New York (Baltimore: The Johns Hopkins University Press, 1998), 69.

${ }^{60}$ Robert Livingston to Alida Livingston, 21 April 1714 from New York City. "Sh" referred to shillings, and was based on the British shilling. The Dutch also used gulden, or gold coins. 
paid for with flour in the space of 3 weeks." ${ }^{\text {61 }}$ Unfortunately, Robert had put the cart before the horse by purchasing slaves without having the funds to pay for them and hoped the sale of flour would cover his purchase. On May 19, he wrote, "I am glad to hear, that Nanning is loading the flour at our place, for [I] am very pressed in order to pay for the negroes." Luckily, three days later Robert was able to put an end to this concern, as "the negroes ... sold well." The flour, finally received from Alida via the family's "yacht," had brought 21 shillings, which further alleviated the couple's financial troubles, if only for the moment. ${ }^{62}$

The significance of Alida's administration of the Livingston's gristmill cannot be ignored. Without flour, the couple could not afford to purchase slaves, supply the manor store with its numerous goods or pay off their outstanding debts. Five years after the conclusion of the Palatine program, Robert wrote, I will try and sell the flour on Monday, even if it will be for 9 shillings, in order to pay off the debt." It is unclear whether flour prices had decreased significantly or the Livingston's debts had increased, making Robert desperate to sell his goods for a lower price than in previous years. While Robert frequently stored grain in order to time his sales with the highest market price, in the spring of 1717 he noted, "At last [I] have sold our flour; 9 tons for 9 sh. 6 d. and 2 tons for 9 sh. 5 d.,

${ }^{61}$ Robert Livingston to Alida Livingston from New York, 28 April 1714. Though the Livingstons utilized slave labor and, obviously, engaged in the sale of slaves, slavery is rarely mentioned in the couple's correspondence. In this letter, Robert goes on to inform Alida, "One, the oldest, speaks English well, has been shepherd, (and) has been born at Jamiacia; the other has first come from his land ..."

${ }^{62}$ Robert Livingston to Alida Livingston, 19 May 1714; 22 May 1714. 
mostly in money." ${ }^{63}$ His relief was short lived, however. "I had sold the coarse flour to Rip van Dam for 6 sh. a hundred, but our virtueless negroes have allowed coarse flour for the pigs and other coarse flour to mix up with it, so that I am forced to lose 1 sh. out of every hundred now."64 This must have been discouraging news for Alida, who was already negotiating with local farmers for additional wheat for that season's milling. ${ }^{65}$ When her plight had not improved by the fall, she informed Robert, "I hope you will send $£ 25$ otherwise I don't know what to do."66

As the couple reached the last years of their lives, they continued to be plagued with unpaid debts, many of which they satisfied with the sale of flour, both in the colonies and abroad. In June of 1721, when Robert and Alida were in their mid-sixties, Robert wrote from New York, "I hope that our yacht will be ready soon with a cargo of flour. I would like to stay here long enough to sell that and pay off the debts here. I have denuded myself of money so much that (I) have

${ }^{63}$ Robert Livingston to Alida Livingston, 13 April 1717.

${ }^{64}$ Robert Livingston to Alida Livingston, 18 April 1717. Robert complained about the poor flour again in a letter dated 13 May 1717. It was common for both Robert and Alida to repeat, almost verbatim, some bit of information in successive letters. Because the couple sent letters via friends and business acquaintances, there was no assurance of timely arrival. Therefore, the most important parts of the couple's letters - for instance, those containing business transactions of which the other needed to be aware - were often repeated. Rip Van Dam was a well known exporter who participated in transatlantic trade with the Livingstons. See Matson, Merchants \& Empire, 61.

${ }^{65}$ Alida Livingston to Robert Livingston, 15 April 1717. "Mr. Salsberrie has been here and Varster is in Katskil and wants to give him 5 gu 5 nickels thus I have had to promise him that for we otherwise have too little wheat."

${ }^{66}$ Alida Livingston to Robert Livingston, 14 September 1717. 
less than 30 sh. in money left." ${ }^{n 7}$ In 1726, the couple was forced to hoard flour in the hopes that they could sell it for a high price prior to European harvesting ${ }^{68}$ “They are hardly willing to give 12 sh. for the flour, but I won't sell anything until it is $13 \mathrm{sh} .$. will try and pay the Governor the $30 \mathrm{lb}$. tomorrow. The others have to wait till the flour is sold." ${ }^{69}$ A few weeks later, Robert sold the flour for 12 sh. 6 d. "because [you] my heart, needed the money, which I will send up with our yacht." ${ }^{70}$ The Livingstons also sold flour abroad, which expanded their resources but was a significant financial risk. In May of 1726, Alida and Robert were dismayed to find that a shipment of flour sent the year before had ended in disaster. Robert sadly relayed the news, "I'm afraid that the returns for the 40 kegs of flour sent to Curacao last year have been taken by the Spaniards." Local rumor suggested the captain of the boat had been captured, and Robert

${ }^{67}$ Robert Livingston to Alida Livingston, June, 1721. No specific day was noted on this letter.

${ }^{68}$ Robert Livingston to Alida Livingston, 27 April 1726. This lengthy letter provides a perfect example of the importance of milling/flour sales to the Livingstons. Robert notes the sale of "cornel" or cornmeal and notes, "I have sent up the money received for it...money is very scarce." In the same letter, Robert discusses four men who have been sent to purchase grain for the Livingston's mill and gave Alida instructions on how to direct these men in their negotiations.

${ }^{69}$ Robert Livingston to Alida Livingston, 3 May 1726.

70 Robert Livingston to Alida Livingston, 17 May 1726. Three days later, on May 20,1726 , Robert wrote of the sale of flour, cornel and butter for " $£ 33.16$ - in paper money and 40 daelders." Daelders referred to currency of the Netherlands that often fluctuated in value. "In some parts of the Netherlands it was the same as two Gulden and five Stuivers, while in others it was equal to thirty-two petards." Albert Romer Frey, $A$ Dictionary of Numismatic Names: Their Official and Popular Designations (New York: American Numismatic Society, 1917), 60. Alida needed money to satisfy local creditors and maintain stock in the manor store. 
reported, "I'm afraid our money was in it."71 This was particularly stressful to the Livingstons, as their frequent times apart and recurring illnesses were beginning to take their toll. One month later, Robert reported that Captain Thomas Linch had finally arrived from Curacoa, but had lost "up to nine thousand pieces of eight," 181 of which belonged to the Livingstons. Though the transatlantic trade was certainly not new to the Livingstons, Robert was prompted to note, "it is not proper for us to take chances with the sea; normally it's always lost. However, we must submit to God's providence and not murmur and be contented." 72

Because much of Robert's time was spent in New York City, Alida's duties at the mill were relentless. Despite the couple's hiring of procurement agents, Alida often dealt personally with local suppliers and her letters were filled with the names of prominent local citizens with whom she negotiated. Even in the final years of her life, Robert entrusted Alida with the procurement and pricing of flour for the manor's mill and trade, stating, "I have to leave the issue of reaching an agreement with the people on the price of wheat to you. ${ }^{73}$ Alida's success is evident in both the family account books and letters, where Robert joyfully noted in 1726, "our flour has a good name." Despite the loss of money at Curacao, the

${ }^{71}$ Robert Livingston to Alida Livingston, 12 May 1726. The 181 pieces of eight (plus five reals) was in this instance for butter sold to the West Indies. A "real" was 1/8 of a Spanish piece of eight.

${ }^{72}$ Robert Livingston to Alida Livingston, 8 June 1726. In an 11 June 1726 letter, Robert noted that the loss of " 181 heavy pieces of eight and 5 reals . . . is quite some loss to us."

${ }^{73}$ Robert Livingston to Alida Livingston, 21 May 1726. 
couple continued to sell flour to Jamaica, confident that their "good name" would continue to earn them profits both in New York and abroad. ${ }^{74}$

When studying colonial women's involvement in family business, it is difficult to isolate one spouse's contribution from the other. The lack of records for colonial women and prevalent assumptions regarding colonial women's roles in their homes and communities make it difficult to ascertain exactly what a wife brought to a business partnership with her husband. In most cases, the wife was a silent partner, or femme covert, whose work was indistinguishable from that of her spouse. Alida Livingston was, therefore, an anomaly in the world of colonial businesswomen. Her significance to the Livingston family fortune is documented in every one of the hundreds of letters exchanged by the couple throughout their forty-eight year marriage. Alida's family tree endowed her with an economic and social advantage over most female businesswomen of her time, and it was her hard work and knowledge of the colonial economy in New York that allowed Alida to set prices, bargain with male farmers for grain, and establish a strong working relationship with the manor's tenants and workmen.

Though Alida Livingston's work was necessary, given her husband's absences, it neither diminishes the quality of her work nor the level of the family's success that must be attributed to her. The flour, beer, butter, grain and other goods shipped from the manor to New York City or used for local trade allowed

${ }^{74}$ Robert Livingston to Alida Livingston, 13 June 1726 . The couple may have been willing to risk further shipments based on the news that there were "13 English men-of-war on the way to the west Indies." Robert Livingston to Alida Livingston, 18 June 1726. 
the Livingstons to pay off debts and survive the financial catastrophe of the Palatine naval stores project. When cash was scarce, or market prices low, the couple could trust in a steady flow of income from the manor's trade and exports. Robert's presence in New York City insured the family of political protection, but it was Alida's presence at the manor - and her management of the property's vast resources - that insured the family's financial wellbeing and built a strong financial foundation for generations of Livingston families. 


\title{
CHAPTER 5 \\ MARRIAGE AND THE MATRIARCH
}

\author{
"A wife not rich or mighty grand \\ But like to me in \\ goods or land." - Jacob Cats
}

\begin{abstract}
"Man and wife are one person, but understand in what manner. When a small brooke or little river incorporateth with Rhodanus ... the poor rivulet looseth its name, it is carried and recarried with the new associate . . it possesseth nothing during coverture. A woman as soon as she is married, is called covert, in Latin, nupta, that is, veiled, as it were, clouded and overshadowed, she hath lost her streame..." 1
\end{abstract}

Alida Schuyler Livingston, born and raised under Dutch rule, married and lived the majority of her life in English New York. Married to a Dutchman, then a Scotsman, her relationship with second husband Robert Livingston fulfilled the expectations of both societies. While the early settlers of the New Netherlands had adhered to Dutch principles brought with them from the United Provinces, the English conquest of 1674 and resulting Treaty of Westminster introduced a new set of regulations, and expectations, for Dutch women. The Livingston's marriage, based on these conflicting patterns, became more than a business arrangement. The couple's forty-eight year union was based on love, mutual respect and devotion to family that both transcended and transformed their infamous business partnership. Because little is known of Dutch marital relationships in the New Netherlands, an examination of the Livingstons lives

${ }^{1}$ The Lawes Resolutions of Womens Rights (London: 1632). 
together also offers a unique perspective on both the Livingstons relationship and marriages in colonial New York during this transitional period. ${ }^{2}$

Alida's first marriage, to Dominie Nicholas Van Rensselaer of Rensselaerswyck, took place in 1675 and ended with the Dominie's death in 1678. It is unlikely that Alida, almost nineteen years of age when she married, undertook the union because of her love for the much older minister. As members of the prominent Schulyer and Van Rensselaer families, Alida and the thirty-nine year old Nicholas likely married for economic and social reasons, as did many of their social peers. Though no records of their courtship exist, the ceremony took place only three short months after Nicholas's arrival in the colony in October 1674 and "was very likely arranged." The hastiness of the wedding seems particularly unusual, as Dutch couples typically entered into long betrothals. (The couple's union never produced children, however, which undoubtedly stilled any local gossip).

Despite their differences in age, Alida and Nicholas Van Rensselaer had much in common. Each understood fully the importance of maintaining family wealth and prestige in the burgeoning colony, and each had been raised to fulfill societal and family obligations. Each also belonged to one of the most influential families in New York. Historians Jaap Jacobs and Herman Wellenreuther assert that Van Renssealer likely pursued the Schuyler's daughter "with the intention to strengthen his position in New York society and in an effort to garner support" for

${ }^{2}$ Fabend, Sex and the City, pp. 3-4. Fabend notes that most studies of the Dutch family in New Netherland focus on legal and economic matters. Glimpses into the family life and relationships of Dutch men and women are rare. 
an impending battle with the American branch of the family- namely his sister-inlaw, Maria Van Courtlandt - over control of Rensselaerswyck. As a newcomer to New York, the Dominie needed the social status and respectability afforded by marriage to a prominent citizen. Nicholas and Alida's nuptials linked two of the most powerful social forces in colonial Albany. ${ }^{3}$

Marriage to the "unorthodox dominie" was surely a difficult transition from life at home for the young Alida. As the daughter of wealthy and respected citizens, Alida could not have foreseen the difficulties she would experience as Van Rensselaer's wife. Prior to their union the Dominie had failed at most every trade he attempted in Holland, and even after proving his devotion to the church was often in hot water with local religious and community officials during their almost four years of marriage in Albany. Prior to the couple's marriage, Nicholas's family had feared for his wellbeing, and likely the Van Rensselaer reputation, when, in November of 1658, he traveled from Holland to visit the exiled British monarch, Charles Stuart, in Brussels. The purpose of his trip - to reveal his religious vision in which Charles II would reclaim his throne - shook the Van Rennselaers to the core. Though the vision obviously sat well with Charles Stuart, who eventually responded with generous favors upon his return

${ }^{3}$ Jaap Jacobs and Herman Wellenreuther, Jacob Leisler's Atlantic World in the Later Seventeenth Century (New Brunswick: Transaction Publishers, 2009), 84-85; Brandt, An American Aristocracy,19-20, 28. The exact date of the Van RennselaerSchuyler wedding is unclear, but was likely within the month of January 1674/75. Because Alida was born in February, it is unclear if she was 18 or 19 years old at the time of her wedding. Brandt also notes the Schuyler family's recipe for wedding cake, which called "for twelve dozen eggs, forty-five pounds of raisins, twenty-four pounds of currants, four quarts of brandy and one quart of rum all mixed together in a washtub." The typical Dutch family could not have afforded such a lavish cake. 
to the throne, the Van Rensselaers were shocked and "imprisoned him [Nicholas] first in his home in Amsterdam, and then in a house in Delft, on the pretext that he was insane." Luckily, the family had wealthy relatives and land in the New World, and by 1675 Nicholas was established as Dominie of the Dutch church at Albany where it was hoped his behavior would improve. ${ }^{4}$ There is no evidence to show if the Schuylers were cognizant of their son-in-law's questionable past. Even if the family was aware, the assurance of financial security and status for their young daughter was a strong enticement to approve of the arrangement, which Pieter and Margarita Schlectenhorst could have denied. In Dutch culture, the standard "age of consent for brides was twenty" and Alida was only nineteen. Whatever the reason, the Schulyers were willing to accept Nicholas into their family without apparent reservation. ${ }^{5}$

The chaos surrounding the young minister soon followed him to his new home. As early as September 1675, less than a year after the couple wed, Reverend William Van Nieuwenhuysen complained to the Classis of Amsterdam about the new minister "who has been palmed off upon the pulpit here, rather than called to it in a legal way." Nicholas's ordination by an Episcopal official and

4 Lawrence H. Leder, "The Unorthodox Dominie: Nicholas Van Rensselaer." New York History, 35 (1954), pp. 166-176. Nicholas was ordained by the Bishop of Salisbury, and served as Minister to the "Embassador from the States Generall residing at London ... Minister of ye Dutch Church at Westminster, and Lecturer at St. Maragaretts Loathbury in London."; Ecclesiastical Records, 678-79. America was a convenient place for wealthy families to send wayward members during the colonial period.

${ }^{5}$ Zimmerman, The Women of the House, pp. 52-53. The age of consent was usually considered twenty for females and twenty-five for males. However, Zimmerman notes that "it was considered ill-advised for parents to micromanage a daughter's choice of a mate." 
not the Classis of Amsterdam, one of his many favors from Charles II , riled tempers in Albany and caused dissention in the church when Van Nieuwenhuysen denied Van Rensselaer the privilege of baptizing children. The young dominie allegedly asked Van Nieuwenhuysen what offence he had committed, and, "said Dominie replyed aloude in ye street, that it was because he did not looke upon him to a lawfull Minister." Van Nieuwenhuysen denied the conversation, but admitted to the Albany council that he believed "no minister, called in Holland...would be permitted...to administer the sacraments in any one of the Episcopal Churches of England without previously promising to maintain and following the Canons, Articles and Rules" of said church. ${ }^{6}$

Fortunately for Van Rensselaer, his close ties with England, and with Governor Sir Edmund Andros, helped to turn the matter in his favor. Van Rensselaer retained his seat as minister of Albany and Rensselaerswyck, but only after signing a pledge of conformity to the Dutch church. ${ }^{7}$ The constant conflict between Van Rensselaer and the citizens of Albany must have been an embarrassment to Alida, a young wife of nineteen and a newlywed of several months. Unfortunately, Van Rensselaer's difficulties in Albany had only just begun.

6 The Dutch Reformed Church maintained services and liturgy in Dutch and helped settlers retain the religion and customs of the Netherlands. A minister ordained by the Episcopal Church would certainly have been an anomaly.

${ }^{7}$ Difficulties in the Dutch Church At Albany, September 25, 1675; Defence of Van Nieuwenhuysen; "Promise of Nicholas Van Rensselaer To Conform To The Dutch Church," Ecclesiastical Records, 678-681. 
On September 8, 1676 an Albany Council called for the discharge of Dominie Van Rensselear "from his imprisonment" for "some dubious words spoken...in his Sermon or Doctrine." The accusations were leveled by Jacob Leisler and Jacob Milborne. Leisler, a devout Calvinist, took offense at Van Renssealer's interpretation of original sin during a sermon and brought charges against the minister. Van Rensselaer counter sued, and, when Leisler failed to pay security for his charges, he was also arrested. Even local ministers joined in the dispute against Van Renssealer. Dominie Schaets of Albany took up the case and "charged and accused Domine Renslaer with false preaching." While the Dominies managed to resolve their differences amicably in deference to their character as ministers, in October of 1676, "The Governor and Councell, Some of ye Aldermen, The Ministers of the City" decided the Leisler-Milborne case in Van Rennselaer's favor, leaving the bill for court charges in Leisler's hands. ${ }^{8}$ While this should have been cause for rejoicing, Nicholas's troubles were far from over. In a letter to the Classis of Amsterdam dated September 30, 1677, Dominie Casparus van Zueren of Long Island related, "Dominie [Nicholas] Rensselaer who officiated in the Colony of Rensselaerswyck, has been deposed by the Governor on account of his bad and offensive life." Jaap and

${ }^{8}$ Doc Hist III, An Albany Minister in Confinement, 527; Sept. the $18^{\text {th }}$. Mr. Leysler not obeying the Order of the Governor in Councell of the $15^{\text {th }}$ Instant, was by the Governor's speciall Warrant committed in the Custody of the Sheriff, 528; "The Case of Dominie Schaets 529; Dominie Rensselaer's Case, 529-530. Dominie Gideon Schaets was long-standing minister at Rennselaerswyck, having signed his contract with the patroon May 8, 1652; The Rev. Gideon Schaets' Contract," Ecclesiastical Records, pp. 309-310. In a letter to the Classis of Amsterdam dated September 7, 1675, Rev. Gideon Schaets (or Schaats) wrote of "the disorderly preaching of another minister," Dominie Nicholas Van Rensselaer. Ironically, it was the Reverend Gideon Schaets who married Robert Livingston and Alida Schuyler. . . in the Presbyterian Church of Albany. 
Wellenreuther argue that repeated attacks on the minister may have resulted not from his preaching, but from his position as heir to the fortunes of Rensselaerswyck. The assaults on Van Rensselaer's mental status by the Holland branch of the family and the attacks by locals in Albany do appear suspicious. The Holland Van Rensselaers did not want to lose control of their estate and conflicts among several of New York's elite families over other financial matters could certainly have accounted for the personal attacks on the Dominie.

Regardless of the reasons, for Alida, her husband's loss of respect and constant turmoil within the community was surely difficult to bear. Affluent Dutch families took special care to marry their children to spouses of status, and Nicholas Van Rensselaer was by no means revered in Albany despite his family name. Because the couple was not separated geographically, as Robert and Alida often were during their marriage, letters and records of Nicholas and Alida's relationship do not exist. It is imperative, however, to study Alida's first marriage in order to fully comprehend her actions during the forty-eight year union she would undertake with Robert Livingston. Because the couple remained in Albany, Alida was forced to deal with reminders Van Rensselaer's disgrace on a regular basis. Her unwavering defense of Robert Livingston's numerous schemes takes on new meaning in light of her first marriage. The vast correspondence between 
the Livingstons illuminates Alida's dogged determination to defend her second husband's reputation. ${ }^{9}$

When Nicholas died unexpectedly in 1678, he left behind a young widow with obvious economic and social connections. These attributes did not go unnoticed by Robert Livingston, the enterprising young Scotsman who served as "the clerk of courts for Albany and ex officio Secretary to the Albany commissioners for Indian Affairs," as well as Nicholas Van Rensselaer's personal secretary. Born in Ancrum, Scotland in December of 1654, Robert Livingston was the son of Presbyterian minister John Livingstone, whose refusal to take the oath of allegiance to the King required of Scottish ministers after the English Civil War resulted in his exile. Realizing the futility, and danger, of remaining in Scotland, Livingstone moved his family to Rotterdam in the Netherlands in 1663. Robert, only nine years old at the time, grew to relish the commercial nature of the city and by sixteen years of age had entered the world of trade. He had also developed an unusual grasp of the Dutch language, which would serve him well in later years. Upon his father's death in 1672, Robert briefly visited Scotland and in 1673 left his family behind to seek his fortune in the New World. ${ }^{10}$

${ }^{9}$ Ecclesiastical Records, 702; Martha Shattuck, A Civil Society: Court and Community in Beverwijck, New Netherland, 1652-54 (PhD Dissertation, Boston University, 1993), 139. Martha Shattuck aptly claims that "two dozen interrelated families dominated eighteenth-century New York," among them the Van Rensselaers and Schuylers. She also notes that "marriages outside of this kinship network continued ... for the enhancement of the family's economic prospects." This explains the Schuyler's willingness to accept two very risky husbands for their daughter.

${ }^{10}$ Edward Brockholst Livingston, The Livingstons of Livingston Manor: Being the History of that Branch of the Scottish House of Callendar which Settled in the English Province of New York during the Reign of Charles the Second; and also including an 
Livingston originally landed in Massachusetts but by 1674 had moved to Albany in New York, arriving in the city at approximately the same time as Nicholas Van Renssealer. The following year he purchased a home and land in Albany and proceeded to win the favor of Albany's most prestigious families, whom he no doubt encountered while keeping the records of Albany as clerk of courts. Employed by the dominie in 1675, Livingston was acquainted with Alida, and most likely, the Schuyler family, from the beginning of her marriage. Within eight months of Van Rensselaer's demise, his widow became Mrs. Alida Livingston, again with the apparent consent of the Schuyler family. The Van Rensselaers, however, were not pleased. "Family legend" maintains that upon his deathbed the ailing Dominie called for a clerk to record his will. When his secretary, Robert Livingston, entered the sick room, the family purports that Nicholas cried, 'No, no, send him away; he's going to marry my widow!' Unfortunately, Nicholas then fell dead, leaving behind a widow, an enterprising young secretary and a large fortune $\ldots$ but no will. ${ }^{11}$

Alida's courtship with a Scotsman certainly would have been a concern for the Schuyler family. Though Dutch citizens preferred endogamous marriages, the reality of life in colonial America necessitated marriage across ethnic lines. Joyce Goodfriend contends that in New Amsterdam such marriages were "not

Account of Robert Livingston of Albany, "The Nephew," a Settler in the same Province, and his Principal Descendants (New York: The Knickerbocker Press, 1910), 55-57.

${ }^{11} \mathrm{Ibid}, 451$. "There is tradition, still preserved in the family...that this lady's (Alida) first husband, on his death-bed, had foretold her second nuptials with the gallant Scot."; Kierner, Traders and Gentlefolk, 19-21; Brandt, The Livingstons, 21; Calhoun, "Sex and Marriage in New York," 165; Maunsell Van Renssealer, Annals of the Van Renssealers in the United States (Albany: Charles Van Benthuysen, 1888), 21-22. 
uncommon." The West India Company welcomed immigrants to the New Netherlands, making intercultural marriages inevitable. In a study of 264 Dutch women in New Amsterdam, seventeen percent married English or French husbands. Whether these marriages were the result of Dutch girls testing their boundaries or romance is unclear. Regardless of their reasons for pursuing these relationships, few Dutch girls would have entered marriage without parental consent. Goodfriend notes the will of Abraham De Peyster, who directed that any one of his children whose mate failed to meet with his wife's approval would immediately forfeit his or her inheritance. ${ }^{12}$

Regardless of parental acceptance, Dutch girls during the transitional period from Dutch to English law certainly had much to consider. Prior to 1674 , a Dutch woman's marital status was derived from Roman law, which permitted a number of freedoms legally inaccessible to Dutch women of the late seventeenth century. Dutch women who chose usus marriages maintained many of the same rights as a single woman, including the right to own property and share equally in the family's estate. ${ }^{13}$ Though Alida married Robert in 1679, five years after the

12 Goodfriend, Before the Melting Pot, 17, 97; Edwin G. Burrows and Mike Wallace, Gotham: A History of New York City to 1898 (New York: Oxford University Press, 1999), 89; Calhoun, The American Family, 165-166. According to Burrows and Wallace, it was extremely rare for Dutch men to marry outside of the Dutch community. The necessity of maintaining strong family alliances precluded marriage across cultural lines. Calhoun notes, "....intermarriage preserved such racial integrity that... many notable city families continued till recent times with little or no infusion of British blood." (166)

13 Bonnie G. Smith, ed., Women's History in Global Perspective, Volume II (American Historical Association, 2005), 254. See also Lisa Jardine, Going Dutch: How England Plundered Holland's Glory (Great Britain: HarperCollins Publishers, 2008), Chapter 6. 
New Netherlands' transition to English common law, old habits died hard in colonial Albany. Alida's marriage to a Dutch man would have most likely insured for her a number of freedoms inside the home, regardless of the law. Therefore, as one of Albany's leading citizens, Alida's marriage to a young Scotsman with few financial resources must have seemed risky to the Schuylers. However, Livingston's popularity with Governor Sir Edmund Andros, as well as many other influential citizens of Albany, could not have hurt his suit. And, truth be told, Livingston needed a wife. By the late 1670 s the young Scotsman had amassed a number of debts while attempting to break into the profitable Albany fur trade. As a result he had contemplated marriage to a wealthy widow in 1677 but nothing came of his plan. ${ }^{14}$ However, Robert Livingston's Scottish lineage and bachelor status necessitated marriage if he was to reside permanently in Albany. As Arthur W. Calhoun notes, "Bachelors were not in good standing with the Dutch." The fear of promiscuous and slovenly behavior prompted men to marry or become "pariahs" in the eyes of their community.${ }^{15}$ By 1678 Livingston had established himself as a respected voice in Albany's affairs, needed a wife, and his future probably seemed less contentious than that of Nicholas Van Rensselaer. With the help of the Schuyler family, Livingston gained influential contacts that served him well the rest of his life. Cynthia Kierner notes that as early as 1678 Livingston participated in trade with Alida's brother-in-law,

${ }^{14}$ Kierner, 19.

${ }^{15}$ Calhoun, The American Family, 165. Widows were considered, to some extent, damaged goods in the marital marketplace. This may also have influenced the Schuyler's acceptance of Robert Livingston as an acceptable mate for their daughter. 
Stephanus Van Cortlandt, who also helped to supply Livingston's Albany store with merchandise. Most importantly, the new couple staked their claim to the deceased Dominie's estate, a fact which could not have hurt Robert Livingston's suit in the eyes of the Schuylers. ${ }^{16}$

After their nuptials, which took place without the typical lengthy engagement common to a first marriage, the newlywed Livingstons settled into Nicholas Van Rensselaer's home in Albany at State and Pearl streets. Because Nicholas had died intestate, the couple also maintained control of the Dominie's massive property at Greenbush Farm while they pursued their alleged share of Van Rensselaer's estate. The Greenbush Farm boasted a ferry slip which served as Albany's primary transportation across the Hudson, an advantage not taken lightly in colonial days. ${ }^{17}$ The young Livingstons faced off with Maria Van Cordlandt, widow of Nicholas's brother, Jeremias Van Rensselaer, and matriarch of one of the most powerful and prosperous families in New York. Upon her husband's death in 1674, Van Courtlandt assumed the management of her husband's vast estate due to the absence of other male heirs. In 1676, Nicholas Van Rensselaer's assignment as director of Rensselaerswyck dismayed the widow. Upon his death, her hopes for control of the manor were again displaced. Despite constant attempts to sway Robert Livingston, Van Cortlandt was unable to convince him to let go of the occupied properties.

16 Kierner, Traders and Gentlefolk, 21.

17 For information on the layout and architecture of Albany's primary residences, see Waite, ed., Albany Architecture, 109. 
Maria's brother-in-law, Richard Van Rensselaer of Holland, in charge of the Van Renssealer's affairs abroad, engaged in the dispute and letters flew between Holland and New York. In May of 1682, Richard Van Rensselaer wrote Robert Livingston directly regarding his attempt to assume the Van Rensselaer estate. "I understand that contrary to all justice and fairness you keep in your possession the patroon's place and also the farm in the Greyne Bos, without being willing to pay any rent...I have made a note of all that is done and administered by you." Robert Livingston did not fear threats from abroad, however, claiming that after four years the property in Albany would revert to his ownership, a claim the Van Rensselaers considered "an old wives fable." Richard Van Rensselar referred to Robert Livingston as "a solicitor of fraudulent affairs" and cautioned, "I really think that you seriously burned your fingers." 18

In reality, the Livingstons' claim could not have been particularly surprising to Maria van Courtlandt, the Holland Van Rensselaers or any of the leading families of New York. In 1670, Govert Loockermans, one of New York's mercantile elite, had also died without a will. As was typical of elite families, Loockermans was related to a number of other class families who quickly made claims on his inheritance, despite the fact that his wife survived him. Apparently looking to the future, Loockermans' relatives, who included the Van Renssealers, Schuylers, Leislers and Van Courtlandts, did their best to grab their piece of his

${ }^{18}$ A.J.F. Van Laer, ed., Correspondence of Maria Van Rensselaer, 1669-1689 (Albany: University of the State of New York, 1935), 65-69, 79; Richard Van Rensselaer to Robert Livingston, May 4/14, 1682; Statement of Robert Livingston. Robert Livingston claimed, '(I intend) to keep in my possession the farm... as well as his other property." 
estate. When Loockerman's wife died in 1679, her son deeded all of his father's New York properties to Loockerman's stepdaughter Elsie Leisler . . . wife of Jacob Leisler. Families fought over the inheritance for years, and Leisler had certainly remembered local claims against what he believed to be his due from the Loockermans when he made accusations against Van Rensselaer. The claims appear despicable, but were part and parcel of being wealthy in early New York. The difference between Loockermans' estate and that of Nicholas van Renssealer was a very young widow named Alida. ${ }^{19}$

The Livingstons continued to inhabit the Dominie's house and proceeded to make payment on his debts, eventually paying his bills in America to the tune of 5,831 guilders. There is no doubt the Van Rensselaers understood Robert Livingston's attempt to delude them from the beginning of the dispute. As Richard Van Rensselaer reminded Livingston, "According to form and practice of law, one must first publicly post and affix a notice..." before paying the debts of an estate. Livingston's attempt to pay the debts of the deceased without proper notification to the community undoubtedly fell outside the parameters of the law. Robert also disregarded the Dominie's debts in Holland, claiming they did not fall under his authority. Though Alida Livingston's participation in this venture remains noticeably absent from current discussions of her husband's claim, it is apparent that she supported Livingston's endeavor. In a letter to her husband,

19 Leder, "The Unorthodox Dominie," 173-174. Robert Livingston has often been criticized by historians, and was certainly criticized by the Van Rensselaers, for his attempt to grab a portion of the Van Rensselaer estate. Apparently, this was a common occurrence among upper class families when a patriarch died intestate. The problem with Robert Livingston may have been that he conspired more successfully than others. 
Richard Van Renssealer refers to a letter he received from Alida on January 9, 1680, approximately six months after her marriage to Robert. In the letter, Alida claimed, "that he [the Dominie] must have paid for the house partly out of the revenue of the colony." Van Rensselaer stated, "If so, it will be bad business, for ... the Dominie, could not draw from the income of the colony any more than any one of us... How do you think that will be taken? I leave that to you to think over." It is unlikely that Alida wrote to Van Rensselaer without her new husband's consent. Livingston may have incorrectly assumed that his wife's relationship with her former in-laws provided an avenue to their acceptance of his claim. ${ }^{20}$

Livingston attempted to recoup his payments on Van Renssealer's debts with a claim on the Manor of Rensselaerswyck. In a letter to Alida on November 6, 1680, Robert informed Alida of his conversation with Governor Sir Edmund Andros regarding their case, noting "I am not afraid of it, I keep possession." Robert and Alida's assumption of the Dominie's property infuriated Maria Van Rensselaer, who claimed, "I can not bear to see him any longer in possession of the patroon's garden." Even the power of the Van Rensselaer family was little match for Robert Livingston, who, in the words of Maria, "is again held in as great regard as heretofore." Maria's comment referred to Livingston's association with many of the most prominent families of Albany, both through his marriage to Alida and his multiple offices in Albany. Robert Livingston could not have had great faith in the outcome of his pursuit of Rensselaerswyck, but he was able to

${ }^{20}$ Van Laer, Correspondence, 67; 65-69. 
use the loss to his advantage due to several carefully chosen friendships. Throughout their lifetime, the Livingstons maintained close ties with many of New York's governors. Livingston probably knew his weak claims against the Dominie's estate would eventually end in the Van Rensselaer's favor. His friendship with Thomas Dongan, who served as Governor of New York from 1683-1688, resulted in a gift of land that formed the foundation of the couple's financial dynasty. The land grant that would become Livingston Manor served as compensation to the couple for their payments on Nicholas's estate. They also managed to retain possession of the dwelling at Pearl and State streets. While the case did not help the Livingstons' relationship with Maria Van Cortlandt, the rift did not sever Livingston-Van Rensselaer relations. Maria's brother, Stephen, was named director of Rensselaerswyck. His wife was Gertrude Schuyler, Alida's sister. ${ }^{21}$

From the early years of their marriage, the couple was frequently separated due to Robert's business or civic duties, a pattern that remained in the couple's marriage until shortly before Alida's death in 1726. In Alida's first surviving letter, dated November 21, 1680, she writes, "Dearest . . I hope to see you this week." While Alida's family background had certainly prepared her for the hard work of being a merchant trader's wife, Robert's actions on behalf of Albany, and the colony, often kept him away from home for months at a time. In a November 1682 letter, she implored Robert to "please hurry as much as you can." In addition to Alida's duties as Robert's wife and business cohort, she was

${ }^{21}$ Ibid, 57, 128. 
now a working mother and managed a store in the family's Albany home. Because of these absences, the most noteworthy moments of the Livingston family were recorded, rather than experienced, by Robert. When son Gilbert was born in March of 1690, Robert recorded his birth in the Livingston family Bible. "My fourth son was born and named Hubertus (Gilbert) after my wife's brother... On the fifth day he was baptized ... I was commissioned by the authorities to go to the colonies of New England." Livingston, embroiled in the fervor of Leisler's Rebellion, had missed the birth of a son, a pattern that continued throughout the couple's marriage. ${ }^{22}$

Records of the couple's early years together, during which they raised their older children into adolescence, are sadly lacking. During the period of 1680-1697, only five letters remain. While it is difficult to ascertain what occurred in the couple's marriage during these years, the significant correspondence of their later years at the Manor provides a compelling look into the couple's lives together. The Livingston's relationship during these years cannot be separated from Robert's merchant and political responsibilities. As Robert's importance to the colony blossomed, so did Alida's responsibilities on his behalf at Albany, where she served as his closest ally and defender in times of conflict. Their correspondence also reveals Alida's determination to protect Robert from the public ridicule engendered by her first husband.

${ }^{22}$ Alida Livingston to Robert Livingston, 21 November 1680; Livingston, Livingstons, The Livingstons of Livingston Manor, 68. Leisler's Rebellion and the fear of Native American attacks provided the impetus for Alida and the children to join Robert in Connecticut. This appears to be the only time that the couple traveled, or were absent from the manor, at the same time during their marriage. Alida did venture to New York City twice, but Robert was at the Manor on both occasions. 
The two years prior to the Livingstons move to the Manor were filled with separation and almost continual difficulties. Alida's duties expanded even further to include the provisioning of troops at Albany during Robert's trips to New York. In May of 1698, a very pregnant Alida expressed annoyance at the unrelenting requests of local officers for provisions. "Please send 4 dozen steel shoebuckles the officers think that you have nothing else to do but bother with their things." $A$ few weeks later, she reported that Captain Wims "can not speak a good (word?) about...you ... [he] came to me to advance him money but I said that I had no order thereto after he had used such malicious words now he can wait himself for the money." Two months later the situation had not improved. "Captain Wims does nothing but reel against you because of the provisions that they are no good." She expressed hope that more fresh items would be received in order to "sweeten things a bit." Alida's annoyance overflowed to Robert, to whom she complained, "you don't send me any... apples for none are to be gotten here for it seems that you do not think much about us." ${ }^{23}$ Alida's comments appear harsh when not placed within the context of the situation. An advanced state of pregnancy, a sick child, lack of provisions and complaints from local officers certainly justify some exasperation on Alida's part. From May through September of 1698 , the family had also experienced a number of financial setbacks - a strain on any marriage. Severe flooding in the Albany area that spring resulted in "such a high water as there never was before" in the Albany

${ }^{23}$ Alida Livingston to Robert Livingston, 28 March 1698; 19 May 1698; 13 June 1698; 25 August 1698; 12 September 1698. On May 19, Alida informed Robert that daughter "Naetje" had been sick for two days. 
area. The primary source of water to Livingston Manor, Roelof Jansen's Kil, overflowed. Alida's letters share the fact that in some areas there was "great damage" and in others, "lots of land disappeared." By August, the Livingston's ability to provide for the military, and themselves, became difficult as the results of heavy spring flooding were finally realized in poor crops. Alida complained, "I am now without money or beavers and pelts ... I do not know where we will get grain for the people to eat....there is a poor pea harvest here because of the heavy rains." When Robert bought an item that Alida found cheaper elsewhere, she made sure he understood that she was "very amazed" at his behavior. When he sent her "8 frocks/skirts" that were of poor quality, she reprimanded him soundly. "I am surprised that you allow yourself to be thus cheated by the Jew." 24

Like most women of Dutch descent in New York, Alida adopted the practice of frankly advising her husband on financial expenditures, traits learned by Dutch girls to protect themselves in case of the untimely death of a spouse. These skills served women well, as epidemics - such as the "hot sickness" and "chin" or whooping cough, made widows of many colonial women. Margaret Hardenbroeck of New York, head of a vast shipping empire, lost her first husband, Pieter, when she was only twenty-one. His untimely death left her with, "a business to run, a fleet to sail" and a one-year-old daughter. Like her Dutch peers, biographer Jane Zimmermann notes, "Margaret was not the type to let the business wait while she wept at the graveyard." Shortly after his death she

${ }^{24}$ Alida Livingston to Robert Livingston, 29 September 1711. 
purchased the King Charles and continued trading in his absence, eventually becoming one of New York's wealthiest citizens. Widowhood also forced Maria Van Courtlandt to display her business skills. The Van Renssealers initially named Maria's brother, Stephanus Van Courtlandt, official director of the manor after her husband's death but left management of its everyday affairs to his widow. Despite health problems that required Maria to walk on crutches, her administration of the estate showcased an uncanny knack for business that seemed to be part and parcel of a Dutch woman's experience. ${ }^{25}$

Alida's connections within the Albany community allowed her to advise Robert because she had access to community gossip and events that Robert did not. Simon Schama claims that it was common for Dutch women to act as a "privy counselor: the person to whom a husband ought immediately to turn for advice and help . . . either domestic or worldly." ${ }^{26}$ In October of 1698, Alida advised Robert regarding his choice of a renter for one of their homes. "I would prefer Meyls Vaster above anyone else for they say that he is doing better and better." For Alida to have remained silent when she had information that could have an impact on the family's affairs would have been foolish. The same month Alida said, "You write about what company the governor maintains that is not

${ }^{25}$ Zimmermann, 62, 65-67; Alida Livingston to Robert Livingston, 28 March 1698; 19 May 1698; 13 June 1698; 25 August 1698; 12 September 1698. For information on Dutch women's preparation for business, see Dorothy A. Mays, Women in Early America: Struggle, Survival and Freedom in a New World (Santa Barbara: ABC-CLIO, 2004), 121.

${ }^{26}$ Simon Schama, The Embarrassment of Riches: An Interpretation of Dutch Culture in the Golden Age (New York: Alfred A. Knopf, 1987), 422. 
proper for us to say he cares a good deal about our side but is much over at dominie's." ${ }^{27}$ Though Alida did not feel comfortable questioning the Governor's motives, she made sure to keep Robert informed of his actions when it was in her power to do so. In May of 1698 Alida cautioned, "I hope you will you're your own affairs and deal with no one but your own business... please do write me what is happening there with your affairs. ${ }^{28}$ The Livingstons relationship was on an equal footing. Alida shared important information with her husband but expected that he reciprocate.

The family's move to Livingston Manor in 1699 opened a new chapter in the couple's relationship. Used to managing the family store and raising children, Alida's duties expanded exponentially during the manor years. In addition to managing the manor's sawmill, gristmill, bakery and brewery, Alida was responsible for delivering on the Palatine victualing contract which almost destroyed the couple's finances. It becomes obvious, as the couple's letters abound during the manor years, that Robert increasingly became Alida's emotional support, if only through correspondence. After a particularly harsh month during the Palatine escapade, Robert wrote, "However, my love, don't be faint-hearted. The Lord God has helped us through so many a time; He will go on helping us through ... The Lord be with you and help you." Three days later,

27 Alida to Robert 1 October 1698; 2 October 1698. In the letter dated October 1, Alida's writing style lent itself to some confusion in interpretation. She said, "I have sent you the list of the goods you write about what company the governor maintains...." The phrase "you write about" could either end the previous sentence or begin the sentence regarding the governor's dealings. The spelling of Domenie is also incorrect and will henceforth be changed to "Dominie" for continuity.

${ }^{28}$ Alida Livingston to Robert Livingston, 19 May 1698. 
in an unusual display of despondence, he wrote, "I am very sad here... If we were not in trouble I should like to live quietly in the country." For Robert, however, living in the country meant facing his many local creditors. In August of 1711 he lamented, "[l]hope to be with you soon, but if it is without money it'll (sic) be sad." 29

Alida responded to Robert's discouragements with her usual forthright advice. When rumors reached the governor regarding the Livingstons' poor provisioning of the Palatines, Alida advised, "he [the governor] will see pretty soon who is his friend or his flatterer." The lies, allegedly spread by John Cast, the Palatine overseer, drove Alida to distraction, and her anger spilled over to her children. "When he arrived at the Manor "and called you a swindler" son Robert "called him all the rotten bastards and devils in the world so I had enough to do to quiet him down." Robert managed to resolve the matter during a conversation with the Governor, but Jean Cast continued his attacks on the family. Robert, aware of Alida's angst on his behalf, wrote, "Mr. Cast has ... a letter... as long as my arm ... written about everyone and about me too...do not pay attention to it." ${ }^{30}$

${ }^{29}$ Robert Livingston to Alida Livingston, 23 July 1711; 26 July 1711; 6 August 1711. Robert probably wrote "it will be sad." In footnote 4, Jos Van der Linde notes that Robert really did sign the letter "your beloved wife." Whether this was a joke or simply an error made in haste is unclear.

${ }^{30}$ Alida Livingston to Robert Livingston, 8 November 1711; 15 November 1711; 24 April 1712; Robert Livingston to Alida Livingston 22 August 1712. On 12 November 1711 Robert was happy to report to Alida that he had spoken with the Governor and straightened out the issue regarding Jean Cast. Robert reflected, "So the whole affair is over, but still we have no money." 
Like Laurel Thatcher Ulrich's "Good Wives" of New England, the Dutch society of the New Netherlands also expected wives to provide "material, spiritual, emotional . . comforts" to their spouses. The idea was certainly easier in theory than in practice, however. The necessity of Robert's absences from Livingston Manor dictated that his wife provide this support from afar. As the couple aged, their concern and affection grew into a tenderness that is not as evident in their earlier letters. In May of 1717 Robert wrote, "If [you] my heart, are short of sugar or tea or anything, please, do let me know. My body is here, but my soul is with you. If I did not think that it was for the family's welfare, [I] would rather be home." As the years went by, the couple also experienced frequent bouts of illness that caused particular concern. In addition to her own struggles with bad health, Alida reported a local epidemic in September of 1717. "It is such a miserable/sickly time there is not nearly a house free... six or 7 died already." Two weeks later she complained, "can not sleep ... one hour in a whole night I can not be left alone." It appears that Alida succumbed to the local epidemic. The previous year Alida's heatlh was so poor that Robert left his political and merchant duties in New York to attend to her at the manor. Son Robert noted, "[Mother] is taken with an extream fitt of sickness...she is siz'd with an extream pain all over her Body as if her blood was stop'd in its circulation." Robert, Jr. obviously agreed with the colonial perception that most illnesses resulted from "an excess of a humor" or "corrupted humors." The symptoms of her illness, which indicated influenza or pneumonia, resulted in phlegm that was "hard" and signified to the Livingstons that she suffered from an improper flow. 
Alida recovered well despite her family's anxiety, but continued to suffer various illnesses the remainder of her life. Robert's willingness to leave his political and merchant responsibilities in New York indicates the strong relationship that tied the couple together. The Lord of the Manor rarely left business unattended, but stayed at his wife's side for six months in $1716 .^{31}$

Robert Livingston also suffered from frequent health issues during his latter years, and much of the couple's correspondence during this time noted the transfer of medications and attempted cures for his frequent kidney problems. In October of 1720 , Robert requested that Alida, "Make them cut off the hair of the horse-tails and mane ... for making a bed and (a) chair, which is very healthy for my ailment." A few weeks later, he related, "[I] have been as bad as I have ever been, for I was not able to stand on my own, much less walk... It was all in the kidneys." Illness continued to plague the Lord of the Manor the following spring, when he noted he was "very painful in this dark weather and go seldom outside." Alida also experienced frequent illnesses during the latter years of her life, often alarming her husband. In June of 1722 Robert wrote, "I am very distressed at the news that my dear's legs are swelling so much! The doctor has sent a little pot with 18 pills ... will make the swelling disappear, and I hope that I will hear shortly that [you] my love are better." One week later Robert informed Alida, "This goes with Dr. James Ogilbie, who intends to settle in our manor as a

${ }^{31}$ Ulrich, Good Wives, , 117; Robert Livingston to Alida Livingston, 3 May and October 2, 1717; Robert Livingston, Jr. to "his brother" as quoted in Sara S. Gronim's Everyday Nature: Knowledge of the Natural World in Colonial New York (Brunswick: Rutgers University Press, 2009), 38-42. 
doctor... but ... he absolutely cannot board at nor reside with us...we are old people and cannot have dealings with any strangers." He added, "Well, such a man is necessary since one doesn't have any in all our regions." Robert rejoiced on June 19 "that you are somewhat better and that your legs are no longer swelling." Robert was certainly thankful, especially as his one attempt at securing a physician for his wife had ended poorly. Alida sent him packing with a stern rebuke. ${ }^{32}$

As Robert aged, his letters contained growing references to the afterlife that awaited him. In June of 1723 he praised Alida for her "sedulity in all things in order to gather fat beasts (and) to keep the mills and land and fence in order. It is a lot of trouble for you, but it seems it's our fate to have trouble in this world. Let us take consolation that time is only short and that we will be released from all worldly difficulties." Robert's continued ailments undoubtedly prompted an evaluation of his future, as he noted in the same letter, "I am losing a lot of sand. The doctor said he has never seen the like." Lest his wife despair over this admission, he encouraged, "do yourself good . . . take someone to keep you company and divert you." Years apart had taught Robert to allay his wife's fears as much as possible, particularly since kidney stones plagued the elder Livingston for most of his remaining years despite numerous attempts at cures. The very next day he noted, "I am...tormented by great pain." While Robert suffered in New York City, Alida lay sick at the manor with "the hot fever . . . and

${ }^{32}$ Robert Livingston to Alida Livingston, 12 October 1720; 18 October 1720; 13 May 1721; 5 June 1722; 12 June 1722. 
sore eyes." Robert expressed anxiety at the lack of letters during his wife's illness and expressed great relief upon receipt of her letter ${ }^{33}$.

The Livingstons' correspondence clearly indicates an affection that exceeded an economic partnership. Their love and devotion grew despite years of hardship and financial insecurity. However, these letters also offer priceless insight into the relationship between English and Dutch ways - and English and Dutch couples - in late sixteenth and early seventeenth century Albany. Alida's marriage to Nicholas Van Rensselaer took place in 1675; her marriage to Robert Livingston in 1679. Despite the short time span, much had changed in the colony by the time of her second nuptials. The final British takeover of the New Netherlands had occurred in 1674, just a year before Alida's first wedding. Though the British assumption of power in New York was hasty, the acceptance of English ways by the Dutch was not, particularly in Albany. Though generations of Dutch women had chosen to enter marriage with the status of sole femme, maintaining their maiden names and the rights of a single woman, Alida Schuyler became Alida Livingston immediately upon taking her vows. Though Alida retained much of her Dutch heritage, she often subjected herself to many English customs during her forty-eight years with Robert. The newly married Livingstons dwelled in a society where Dutch and English ways vied for dominance, and their marriage exemplified a blending of the old with the new.

Joyce Goodfriend argues, "By adapting to their new environment, their [Dutch colonists] transformation into Dutch Americans had begun." ${ }^{34}$ This was

${ }^{33}$ Robert Livingston to Alida Livingston, 14 June1723; 15 June 1723; 1 July 1723. 
not entirely true in Albany or at Livingston Manor, largely due to their distance from the center of power and government in New York City. As late as the mideighteenth century - long after Alida's death - most citizens of Albany continued to speak and write in Dutch as well as maintaining customs brought with them from the homeland. Government positions in the Livingstons home city were held almost exclusively by Dutchmen until the mid-eighteenth century. In a letter to Robert dated March 24, 1698, Alida wrote, "The French governor said that Albany is being governed by Dutchmen and that they cannot believe that it [is] an English government...so the French mock us." While it is easy to assume that this Dutch heritage dominated not only Alida's community but also her marriage, there is strong evidence to the contrary. According to Patricia Bonomi, Dutch settlers at Albany were known to be "clannish" and resistant to outsiders ${ }^{35}$ Under these conditions, it appears odd that Alida Livingston would convert to English ways, but her husband's ties with colonial English governors, such as Thomas Dongan and Robert Hunter, provided the couple with victualing contracts - and personal connections - that served the couple well for many years. The Livingstons' dependence on the friendship of these governors may have served as an impetus for Alida's moderate assimilation into English culture. ${ }^{36}$ The Livingstons also embraced both English and Dutch citizens as their

${ }^{34}$ Goodfriend, Before the Melting Pot, 18.

35 Patricia U. Bonomi, A Factious People: Politics and Society in Colonial New York (New York: Columbia University Press, 1971), 26, 51.

${ }^{36}$ It should be noted that Alida Livingston never learned to write or read in English. However, this probably had more to do with limitations on extensive Dutch education for females than an adherence to Dutch customs. Even in Dutch, Alida did 
friends, in direct opposition to the "clannishness" often recorded amongst Dutch circles in Albany. On February 8, 1698, Alida regaled Robert with her plans for an upcoming ride with "Madam Inghelsbie," wife of Major Richard Ingoldsby, the commander of Fort Orange. The major's wife maintained an unusually close relationship with Alida Livingston, one of the few mentioned in her letters. Madam Ingoldsby traveled between New York and Albany, an arrangement of benefit to the Livingstons when information needed to be delivered in person. In March of 1698, Alida informed Robert, "Madam Inghelsbie will tell you all about what the French do say about our Domenie.."37

Marriage to a Scotsman often forced Alida Livingston to choose sides between the community and her husband. Their letters reveal that she chose to support Robert Livingston without fail. In a letter to Robert dated January 25 , 1698, she wrote, "if you are not continued in your service which the King granted you then I will not live amongst these people for they hate everything having to do with an Englishman." Alida Livingston's situation was certainly rare. Her marriage to a Scotsman at times conflicted with her Dutch heritage. Dutch citizens - many of them Alida's relatives - dominated colonial Albany's political and civic infrastructure. In his description of the customs of colonial New York,

not use punctuation and often spelled phonetically. None of the letters to or from Alida in the family's correspondence are written in English.

${ }^{37}$ William Henry Paddock, The Police Service of Albany from 1609-1902 (Albany: The Police Beneficiary Association of Albany, 1902),13. February 8, 1698; Alida Livingston to Robert Livingston March 24, 1698. Major Ingoldsby worked closely with Robert Livingston and Alida's brother Peter Schuyler, then mayor of Albany, to maintain social order in Albany in 1693 under martial law. The Ingoldsbys maintained close contact with the Livingstons. Alida sent "Greetings to madam Inghelsbie" in an April 11, 1698 letter to Robert. 
Sydney George Fisher describes, "a sullen though quiet hostility of the Dutch against the English." Up to the American Revolution, many Dutch families, regardless of status, refused to sell land to Englishmen or to allow them a "foothold" in Dutch society. Though the Albanians generally accepted Robert Livingston and often admired his work on behalf of the colony, times of trouble also made him easy prey for their hostilities. In the spring of 1698 , a patent issue involving "50 miles of Mohawk River shoreline" caused some members of the community to become "so hated that the community does not want to hear their names." Several citizens wanted Robert's assistance in settling the dispute, which had become so severe that members of the Dutch Reformed Church threatened to stop payment of the local Dominie's salary for his involvement in the affair. The Dominie, Godfredius Delius, turned on the Scotsman, spreading rumors designed to destroy his credibility. Alida sided fully with her husband, offering some of her most scathing comments about her Dutch neighbors, referring to their lies and rumors and calling them "enemies."

Any scholar of the Livingston family understands fully Alida's importance to the Livingston family's success, both business and personal. While some historians might claim that Alida's success stemmed from her ability to retain her Dutch customs, in reality Alida Livingston had no more power over the law than any other woman in the colony, either in business or in marriage. Prior to the

38 Blackburn and Piwonka, Remembrance of Patria, 65; Alida Livingston to Robert Livingston, January 12, 1697/98; January 25, 1697/98; Sydney George Fisher, Men, Women \& Manners in Colonial Times Volume II (Philadelphia: J.B. Lippincott Company, 1898), 101. Robert's absences from Albany often left Alida in precarious positions with local citizens who were angry at her husband for various reasons. 
English conquest, Dutch women, both single and married, operated businesses in their own names, conducted legal matters independently and often wrote joint wills with their spouses. Inheritances were generally granted equally to each child, unlike the practice of primogeniture common to the English. Though these practices "technically" ended under English rule, many Dutch families did maintain the practices until the early eighteenth century. In February of 1686, Frederick Hendricks DeBoogh of New York gave his wife, Elizabeth Salomons, everything he owned, "with full power to sell." If she remarried after his death, half of the inheritance was to go to her children. Just a few months later, Elizabeth Salomons appointed tutors for her children in her own brief will. ${ }^{39}$ As late as 1714 , citizens such as Christine de Boore chose to leave equal, or larger, amounts to daughters than to sons. DeBoore left all but 10 shillings to her daughter, naming her executor of the will. Son John was left the 10 shillings. $^{40}$ The Livingstons, however, did not write joint wills, nor did the Livingston children inherit property equally. The Livingston's marriage and family life, though lived in a Dutch city, bore many striking resemblances to marriages and families in English society. ${ }^{41}$

${ }^{39}$ Abstract of Wills, 446. The will of Frederick Hendricks DeBoogh is dated February 22, 1685/6 and his wife, Elizabeth Salomons's will, is dated April 3, 1686.

${ }^{40}$ Ibid, 249. 16 March 1714.

${ }^{41} \mathrm{Ibid}, \mathrm{pp} .341-348$. While daughters Margaret and Joanna did not inherit the Manor of Livingston, both benefitted in their father's will. Margaret inherited Robert's "biggest house and lot in Dock Street" and "£100 for the altering and repairing of said house." Joanna received the "lesser house and lot in Dock Street" and "£200 for repairs." Both homes, some of New York finest, had been purchased by Robert Livingston from Captain William Kidd. 
Robert's 1679 description of his new bride as a "worthy helpmeet" rang true throughout their long marriage. Alida Livingston remained her husband's friend, confidant and supporter through the numerous trials of colonial life. While her Dutch upbringing demanded that she excel at the economic side of marriage, life in the English colony of New York necessitated that she also adapt to new laws and social customs to support her husband successfully. Though her peers in Albany remained strongly committed to their Dutch ways, Alida defied convention in order to effectively support her marriage. The couple's devotion, which appears to have been heavily focused on economic matters during the early years of their union, grew into a loving relationship based on mutual affection. For the Livingstons, love could not be separated from economic and political duties. Alida Livingston's Dutch background taught her to prove her devotion through exemplary household management and the protection of her spouse. She excelled at both, and Robert and Alida Livingston's many years together provide a compelling look into the family life of an elite Dutch couple in early New York. 


\section{CHAPTER 6:}

Alida as Mother

"Like leaves on trees, the race of man is found, Now green in youth, now withering on the ground; Another race the following spring supplies: They fall successive, and successive rise." - Alexander Pope ${ }^{1}$

Alida Livingston, often lauded for her business acumen, was also a successful mother, who, despite her husband Robert's frequent absences, raised six children to adulthood, taught her offspring the rudiments of the business world, and, while doing so, established strong family relationships - and a financial foundation - that made the Livingston family a force to be reckoned with in New York society.

Though Alida Livingston was the matriarch of one of the most prosperous families in colonial New York, daily life during the late seventeenth and early eighteenth centuries was by nature harsh and demanding, regardless of status. While managing the family's business interests in Albany and at Livingston Manor, Alida Livingston gave birth to nine children, managed household servants and slaves, and maintained a close relationship with her husband - mostly through letters exchanged on an almost daily basis. Because of the Livingston family's commercial and political interests, their children were supervised by parents who were often apart. Robert Livingston's involvement in political and merchant affairs in New York City demanded that Alida govern the family business - and family home - in his absence.

\footnotetext{
${ }^{1}$ Printed in Livingston, The Livingstons of Livingston Manor,132.
} 
Though the Livingston family has been the source of much historical interest, researchers have virtually ignored the relationship between Alida, Robert and their children in favor of illuminating Alida's successful trade ventures. $^{2}$ However, despite her success as a businesswoman, Alida Livingston could not escape the fact that seventeenth century society required more of women than financial achievement. Colonial society judged women, regardless of their economic status or entrepreneurial abilities, largely by their success - or failure - as mothers. In her groundbreaking study of the women of colonial New England, Laurel Thatcher Ulrich notes that husbands and fathers of the colonial period were largely remembered for their legacy of property, whereas wives and mothers were remembered for their reproductive feats. For women of the seventeenth and eighteenth centuries, "the concept of motherhood was closely tied to fertility. ${ }^{3}$ Alida Livingston, like most colonial women, spent much of her married life in a cycle of pregnancy, nursing and childrearing. From 1680 to 1698, she gave birth to nine children. In 1680, at the age of twenty-four, Alida gave birth to John, followed by Margaret in 1681, Johanna Philippina in 1684,

2 James M. Molo and Dorothy Denneen Volo, Family Life in $17^{\text {th }}$-and-18 ${ }^{\text {th }}$ Century America (Westport: Greenwood Press, 2006)), p. 193. The Volos note that "one in ten infants did not survive the first year, and four out of ten children died before age six." Translations of the children's letters in this study were made by Jos van der Linde, unless otherwise noted. The translations are available at the Franklin D. Roosevelt Library in Hyde Park, New York and originals are on microfilm in the LivingstonRedmond Papers at the Gilder-Lehrman Institute of American History in New York.

2 Ulrich, Good Wives, 159; Volo, Family Life, 39, 193. Motherhood as it is understood today has its roots in nineteenth century Victorian family life. Motherhood, to families of the seventeenth and eighteenth centuries, often referred simply to a woman's ability to give birth. 
Philip in 1686, Robert, Jr. in 1688, Gilbert in 1690, Wilhelm in 1692, Joanna in 1694, and Catharina in 1698, when Alida was forty-two years of age. Johanna Philippina died at approximately age 6, and Wilhelm and Catharina in infancy, leaving only six of the Livingston children to survive into adulthood. ${ }^{4}$ Alida Livingston's nine pregnancies did not make her an anomaly in colonial New York. The birth of so many children did necessitate, however, a life of multiple responsibilities that centered on childrearing but also included oversight of the family business. The isolation of Albany and, later, the Manor, compounded the normal fears of a young mother, whose letters, usually focused on business, often veer from business matters to note with concern the illnesses experienced by her children. In February of 1697/98, she wrote Robert, "our little Johanna has now been ill for 3 days." In May of 1698 daughter Margaret, nicknamed "Naetje," was "very ill" and Alida longed for Robert "to come home again." The loss of one of every three Livingston children surely served to enhance Alida's fears about the health of her offspring. ${ }^{5}$ In their study of family life during the seventeenth and eighteenth centuries, historians James M. Volo and Dorothy

Kierner, Traders and Gentlefolk, 254. Kierner's text contains a very thorough family tree and is a good source of information on later generations of Livingstons. See also Edwin Brockholst Livingston's The Livingstons of Livingston Manor, appendix C. Information in Livingston's text is taken directly from the Livingston family Bible. The loss of three children in infancy and early childhood was common during the colonial period. Volo, Family Life, 193. The Volos note that "one in ten infants did not survive the first year, and four out of ten children died before age six."

${ }^{5}$ Alida Livingston to Robert Livingston, 22 February 1698; 19 May 1698. Robert and Alida's children would also experience the loss of a child. Daughter Margaret lost a son, William, experienced a stillbirth in 1712 and gave birth to a daughter who died in infancy in 1722. Philip lost infants Peter and Sarah in 1712 and 1721 . Robert, Jr. lost son Gilbert in infancy in 1717. The Livingston's youngest daughter, Joanna, gave birth to a stillborn baby in 1733. Overall, the Livingstons lost 7 grandchildren. 
Denneen Volo report a child mortality rate of "between 20 and 30 percent" during the colonial period. The Livingstons' letters do not reveal their sorrow at the loss of Johanna Philippina, Wilhelm and Catharina, but in an era where diphtheria, small pox, and household accidents all too frequently claimed the lives of young children, Alida Livingston's combined responsibility for her family's spiritual, physical and economic well being was a heavy burden to bear.

The most courageous of women would have had difficulty raising children, virtually alone, in late seventeenth century Albany. The frontier settlement and fort of Albany, bordered on each end by "lodges where the Indians were received and entertained during the fur trading season," certainly offered little of the creature comforts available in larger New York City. ${ }^{6}$ By the early eighteenth century, there was still only a scattered population in the area. However, life in Albany, though rough, was still more civilized than life at the manor. Robert received the grant for Livingston Manor in 1686, six years after the birth of their first son, John, but in 1716 the manor only housed 33 tenants. $^{7}$ Because the Livingston parents spent a large portion of their married lives in separate cities due to work and Robert's political ambitions, they relied on correspondence and Albany's sporadic mail service. During the summer sloops

\footnotetext{
${ }^{6}$ Leder, Robert Livingston, 13; Kim, Landlord and Tenant,4. Kim describes Manhattan as "pasture and common for roaming livestock." Though Albany was certainly a frontier community, even the larger city of New York was quite rustic during the late seventeenth century. Alida's family, the Schuylers, resided in Albany, but the couple's letters do not reveal to what extent the Schuylers supported Alida in the raising of her children.

${ }^{7}$ Kim, Landlord and Tenant, 235-236 and fn1. Alida was responsible for supplying the manor residents with necessary supplies, an additional strain on an already busy mother and businesswoman.
} 
carried mail from New York City - where Robert Livingston usually resided in his absences from the Manor - to Albany on an average of once every two to three weeks, or ten days if conditions permitted. Therefore, requests sent to Robert through the mail would have been received and returned in a month's time. Occasionally Indian carriers brought mail from New York to Albany, but again, delivery was at best intermittent. Most of the couple's letters were carried by friends and acquaintances traveling on the sloops between New York City and Albany. The strain of raising six children on the frontier while managing a significant business enterprise at Albany and/or Livingston Manor took its toll on the Livingston matriarch, whose abundant letters frequently reveal the frustrations of single parenting. ${ }^{8}$

The trials of motherhood often frustrated the usually unflappable Livingston matriarch. The hardship of being a frontier mother is revealed in a 1698 letter to Robert, in which a frustrated Mrs. Livingston wrote, "I had thought that you would have sent up the chest there are diapers in which I need." The location of the Livingstons' home required that even the basic necessities of life such as material for diapers - be delivered by sloops coming in and out of New York. On 6 June 1698, after the birth of the Livingstons' last child, Catharina, a forty-two-year-old Alida wrote to Robert, "I was delivered of a young daughter but am very weak of the burning fever and sick out of my head." One week later

${ }^{8}$ In a 26 September 1711 letter from Alida to Robert, Alida notes her concern for the welfare of one of her daughters and wrote, "I feel quite lonely." Comments such as these are rare in the couple's correspondence. It should be noted that the transportation of letters during the winter months would have often been delayed due to inclement weather, as the Hudson frequently froze over. 
baby Catharina still suffered and Alida's frustration was evident. Midwives in Dutch communities regularly instructed women to complete their kraambed, a nine-day "lying in" period that allowed the new mother to regain her strength. Alida, whose letters indicate her discomfort with inactivity, was obviously discouraged. "Our child is in very much fever and won't let go of me. I have nearly no milk which means it has to be brought up with porridge which is a great deal of trouble." By the time of Catharina's birth, the propensity of elite Dutch women to send their children out to wet nurses had been confronted by Dutch author Jacob Cats, who claimed, "One who bears her children is a mother in part, But she who nurses her children is a mother at heart." ${ }^{\prime 9}$ Alida may have been "a mother at heart" but the aggravation of preparing porridge regularly throughout the day added to the already overworked mother's duties. ${ }^{10}$ Though Alida suffered from a fever and was confined to bed, she was not too ill to instruct Robert on the care of their oldest son, John, age eighteen, who was reportedly dating a twenty-eight-year-old woman.

There is talk that our Johannes [John] would be courting after Jacob Rutsen's daughter who is 28 years old and has a mouth as if she has followed the army all her life but he denies it and I have told him what he should expect that I think he would be wiser than to start anything like that as he is only a minor ..." Alida ordered Robert to "Write

${ }^{9}$ Marilyn Yalom, A History of the Breast (New York: Ballantine Publishing Group, 1998), 73.

${ }^{10}$ Zimmerman, The Women of the House, 66. When a Dutch infant turned 10 days old, a kindermaal - or maternity party - was often held by the new mother. Alida's illness would have delayed, or cancelled, this community event which involved special drinks and desserts. 
him about that and give him a reprimand. ${ }^{11}$

Alida could not even name the newborn without Robert's input. She acknowledged the receipt of a cradle sent by Robert from New York, stating, "I will have her baptized please write her name how she will be called." For the Dutch, a child's baptism was a very important affair. According to New York historian Alice Morse Earle, "As soon as the little American baby was born in New Netherland, he was taken to the church by his Dutch papa, and with due array of sponsors was christened . . . in the Dutch Reformed Church." Robert, the son of a Presbyterian minister and Presbyterian himself, had each of his children baptized in the Dutch Church at Albany - no doubt an important step in gaining the trust of the Albany community. The absence of the child's father at such an important time must have been a worrisome affair for Alida, who had also been separated from Robert during the birth of the couple's second and fourth sons, Philip and Gilbert.

More often than not, Alida's comments to Robert regarding the children contained specific instructions on their behavior. On July 10, 1711 Alida wrote to her husband regarding her concerns about their son, Robert Jr.'s, business in New York. "Please set Robert [up] that he will be in a good position to earn his living... let him eat at Mrs. Syepert and let him spend his time well to make gains

${ }^{11}$ Alida Livingston to Robert Livingston,5 April 1698; 6 June 1698; 13 June 1698; Earle, Colonial Days in Old New York,14. The Livingstons were married in the Presbyterian Church and Robert recorded the birth of his son, Robert, Jr., in the family Bible with these words, "May the Lord bless him that he may grow up in the Presbyterian religion. He was baptized... by Dominie Dellius." Livingston, The Livingstons of Livingston Manor, 144. It must be noted, however, that when Robert built a church on Livingston Manor in 1722 a minister of the Dutch Reformed Church was called. 
for himself for idleness does not get one a thing." ${ }^{\text {12 }}$ Six days later, she reminded her husband to help Robert, Jr. get "a good job."13 When Alida believed Robert had not lived up to his parental duties, she complained, "You won't do for your children as other fathers . . "14

Alida's letters frequently expressed a strong concern for the moral and social behavior of her sons, in particular their choice of a good mate. In a letter to Robert dated July 25, 1711, Alida noted her concern for Robert, Jr., saying "I fear he is not in the right house, for she has older daughters...if he minds his business then all will go well." One week later, she wrote, in regard to his behavior toward these women, "I hope that he does as he promises ..." John, whose alleged relationship with a woman many years his senior had alarmed Alida, wrote to his mother, assuring her that "he would not be so crazy as to throw himself away." ${ }^{15}$

As the Livingston children grew into young adults, their mother's responsibilities grew with them. Alida, consumed with business affairs and the management of the family's home, also maintained responsibility for the educational and moral upbringing of her children. Though the Livingstons' male heirs were well educated, little is known of their elementary education. However, in The Dutch Schools of New Netherland and Colonial New York, William Heard

${ }^{12}$ Alida Livingston to Robert Livingston, 10 July 1711.

${ }^{13}$ Alida Livingston to Robert Livingston, 16 July 1711.

${ }^{14}$ Alida Livingston to Robert Livingston, 10 July 1711.

${ }^{15}$ Alida Livingston to Robert Livingston, 13 June 1698. According to Alida's letter, John assured her that he would be careful in his relationships and urged his parents not to worry. 
Kilpatrick notes that funds for the keeping of a "Dutch school at Albany" were granted in 1664, sixteen years prior to the birth of Alida's eldest son, John. Most Dutch schools in America met year round, excluding holidays, from 8:00 a.m. until 11:00 a.m. and again from 1:00 p.m. until 4:00 p.m. An interesting glimpse of life in the early Dutch schoolhouse is apparent in "Contract With a Dutch Schoolmaster, Flatbush, 1682." Aside from Article I, which states the aforementioned opening and closing school hours, the contract mentions only the schoolmaster's religious duties, including the instruction of catechism, prayers and participation in Dutch Reformed church services. This may be due to the petition of New Netherlanders in $1649, \ldots .$. "There ought also to be a Public school provided, with at least two good teachers, so that the youth, in so wild a country . .. may... be well instructed and indoctrinated not only in reading and writing, but also in the knowledge and fear of the Lord."16 Given the Livingstons' location in downtown Albany and Alida's commitment to the Dutch Reformed Church, it is likely that the Livingston children - at least the male heirs - attended such a school for their rudimentary education.

Though education for young girls such as Joanna and Margaret Livingston was not as common under English rule, it was expected that young ladies be educated in Dutch America. In fact, parents often mentioned the education of young girls specifically in Dutch wills of the time period. The Minutes of the

16 "Contract with a Dutch Schoolmaster, Flatbush, 1682" in Archie Emerson Palmer, The New York public school: Being a History of Free Education in the City of New York (New York: Edwin C. Hill Company, 1908), 369-370; "In What Manner New Netherland Should Be Relieved," in E.B. O'Callaghan, ed., Documents Relative to the Colonial History of the State of New York, Volume I (Albany: Weed, Parsons and Company, 1856), 317. 
Orphanmasters of New Amsterdam, 1655 to 1663, reflect the importance placed on education by Dutch families residing in the New Netherlands. In the case of Claes Pietersen Cos, the orphan masters required that he provide for his female dependent "food and clothing, until she comes of age or marries and meanwhile he is to make her learn, as opportunity offers, to read, write, sew and some other useful knowledge." ${ }^{17}$ This request was similar to the requests made of the guardians of male children, such as Pieter Jansen, who pledged "honestly to bring up and educate his son, to make him learn reading, writing, a good trade or liberal art." The Dutch citizens of early New York were simply carrying out the legacy of their forefathers, for "Holland was the sole nation in seventeenthcentury Europe to offer girls primary education as a matter of course."18

Though the extent of the Livingston daughters' elementary education is unknown, both Joanna and Margaret could read, write, and conduct business matters independently, as evidenced in their numerous letters to their mother and father. In Seventeenth Century Albany: A Dutch Profile, Charlotte Wilcoxen claims that most men, and at least one-third of women, signed their names to documents during the Dutch period, while the remaining citizens signed with a mark. However, the ability to sign one's name did not mean that the individual could read or write beyond the signing of his or her name. In fact, Wilcoxen notes, "the number of women signing legal papers was small, and about half of

${ }^{17}$ Fernow, Berthold and Waleyn Der Veen, The Minues of the Orphanmasters of New Amsterdam, 1655 to 1663 (New York: Francis P. Harper, 1902), 28, 35.

${ }^{18}$ Zimmerman, The Women of the House, 74. 
these, perhaps even two-thirds, signed with a mark, among whom were a number of comparatively affluent women." ${ }^{19}$ Mary Beth Norton argues that "children's acquisition of literacy ... depended on whether their parents, and especially their mothers, were literate. Many colonial women seem to have been able to read, but far fewer knew how to write." ${ }^{20}$ Based on these statistics, it is reasonable to assume that Robert and Alida's daughters were among the most educated young women in the colony of New York.

Alida's four sons took varying paths of education. As the eldest son, Johannes (John) stood first in line to inherit Livingston Manor. As the primary heir, he was educated in matters pertaining to the family business endeavors, as his parents' hard work and strategy had resulted in an ever-increasing acquisition of land. ${ }^{21}$ The English practice of primogeniture required eldest sons to prepare to bear the family fortune and name. Though his father and mother strove to keep John focused on his schoolwork, he invariably found other activities more

${ }^{19}$ Charlotte Wilcoxen, Seventeenth Century Albany: A Dutch Profile (New York: Education Department of the Albany Institute of History and Art, 1984), 32. It should be noted that both Joanna and Margaret Livingston wrote in English and Dutch.

${ }^{20}$ Mary Beth Norton, "The Evolution of White Women's Experience," The American Historical Review, Vol. 89, No. 3 (June, 1984), 607. Though Alida Livingston wrote scores of letters during her married years, she spelled phonetically and her writing was not up to the standards of her children. In Traders and Gentlefolk, p. 49, Kierner states, "Alida taught her children to read and write both English and Dutch." As none of Alida's letters are written in English, and Robert's letters to Alida are written in Dutch, it is unlikely that Alida taught her children the English language. In a letter dated May 3, 1717 , son Philip writes to Alida that his father needs a "writ" and is sending someone to pick it up at the Manor. In regard to writing on the writ, he states, "Sister Johanna can write these English words on the back of the writ."

${ }^{21}$ Biemer, Women and Property, 63; Kim, Landlord and Tenant, 39-40. 
interesting. John attended schools in New York and London, but his lack of interest in formal education was a constant source of concern for his parents.

When Robert Livingston returned to New York from his exile in New England after Leisler's Rebellion, he entrusted the care and education of his eldest son to family friend Fitz-John Winthrop of Connecticut, who had little success in educating the Livingston heir. In a letter to Robert Livingston, he commented, "I have allsoe to tell you, to my sorrow, that his improvement in his learning is not soe much as I expected." Winthrop blamed himself for John's lack of education, but the eldest Livingston was simply not meant to be a scholar. In 1691 Winthrop sent John Livingston home to Albany, despite the boy's "feavour and ague" and the poor winter weather that endangered travelers. Though Winthrop doubted the wisdom of the boy's trip, he noted, "Noe consideration but ye sence of his mother's sorrow for his absence should perswade me to venture him thus late in ye yeare."22 In a rare display of emotion, Alida had expressed a longing to see her son; that desire necessitated a dangerous trip in the winter cold. Though demanding as a parent, Alida Livingston also loved her children deeply and mourned their frequent absences from the manor. Had she known what the future held for John Livingston, she might have requested an even hastier return.

To Robert and Alida's dismay, the Winthrop's daughter, Mary, eventually gained their eldest son's interest. The Livingstons were loath to accept John's

${ }^{22}$ Winthrop Papers, in Collections of the Massachusetts Historical Society, Sixth Series, Volume III (Boston: Published by the Society, 1889), 511. Fitz-John Winthrop to Robert Livingston, December 1691. 
relationship, as Mary's parents, Elizabeth and Fitz-John Winthrop, were unmarried at the time of her birth. In 1700 , six years after his initial stay with the family, John returned to Connecticut and announced his intentions to wed Mary Winthrop. On December 10, he wrote to his father, requesting "yours and mothers Blessing and Consent" for the marriage. Desperate, John informed Robert and Alida that he would "Reather Dey than to Leave Hur." In regard to the legitimacy of the Winthrop's marriage, he noted, "you Schrupeld there being married...have asked the minester about it and he told me that they were Sartenley married." A letter to the elder Livingstons from family friend Duncan Campbell most likely helped to secure parental approval for the Livingston heir. Campbell shared the important news that marriage to the Winthrop's daughter would include a "handsome dowry" as their only child, Mary was "sole heir" of the Connecticut governor's estate. ${ }^{23}$ Fitz-John's will of March 1702 did indeed benefit his only daughter. Mary Winthrop's inheritance included numerous properties, "fifty head of cattle; also the new furniture in the new chamber, together with the one half of my household stuff; also what is due to me from the Colony of Connecticut ... the negro girl named Rose...two Indian girls named Sue and Dinah."24 The promise of financial prosperity, coupled with assurances of Mary's legitimacy, swayed the Livingstons' favor. The couple married in 1701

\footnotetext{
${ }^{23}$ Lawrence Leder, "Robert Livinston's Sons; Preparation for Futurity," New York History, 35:2 (1969), 238-241; Brandt, An American Aristocracy, 53-54; Duncan Camptell to Robert Livingston, New London, December 10, 1700; John Livingston to Robert Livingston, December 10, 1700, from New London, Connecticut. Letters located in the Livingston-Redmond MSS.

${ }^{24}$ Winthrop Papers, 415.
} 
and the family's correspondence indicates a mutual love and affection for their new daughter-in-law.

In April of 1701, John and Mary traveled to the manor, an intimidating trip for the new bride. Robert Livingston informed the Winthrops of their arrival, noting, "I doe assure you . . . your daughter shall have all ye incouragement imagineable from me \& my wife...\& shall find such a welcome \& civiletyes as this place can afford. She is so good humord that all her relations here are extreamly taken with her." The Livingstons openly welcomed Mary Winthrop to their family circle, allaying any fears the Winthrops might have had about their daughter's acceptance. After the nuptials, Governor Winthrop wrote personally to Alida, expressing subtle concern about her impending visit to the Manor. "We doe earnestly recommend her to your love and affection, which will be soe much the more generous, as she is a stranger and far from her relations." English law made Robert the head of household, but even Governor Winthrop knew that Alida's acceptance would determine his daughter's happiness in her new marriage..$^{25}$

Mary Winthrop died of cancer on January 8,1713 , and John married Elizabeth Knight, daughter of author Sarah K. Knight, in October of the same year. John's declaration of love sparked a family debate. A short conflict ensued between siblings after Margaret Livingston Vetch and sister Joanna contacted their father regarding John's intended. Not only was their brother marrying in an

${ }^{25}$ Ibid, pp. 66-68. Robert Livingston to Fitz-John Winthrop, April 14, 1701; FitzJohn Winthrop to Mrs. Robert Livingston, April 1701 (no specific date noted on letter). 
inappropriately hasty manner, there was also some concern that the marriage had been instigated by Elizabeth Knight prior to Mary Winthrop Livingston's death. The occupation of Elizabeth's mother may have caused concern as well. Sarah Kemble Knight's authorship of The Journals of Madam Knight, which retold her trip by horseback from Boston to New York in 1704, must have seemed outrageous to the Livingstons. To a family whose world centered on trade, a single mother devoted to education and literature probably appeared somewhat flighty. Madam Knight's letters to the Livingstons, though limited, frequently requested more correspondence and even note a gift of books for Robert. Despite her persistence, several years after the marriage John Livingston continued to beg his father to stop suspecting the worst of Sarah Knight. John never appears to have acquired his parent's approval of his second marriage, nor the Livingston business sense. Livingston biographer Lawrence Leder notes that John's participation in an "illegal trading venture to Canada" with Samuel Vetch - husband of Margaret Livingston - resulted in "parental anguish, especially when New York authorities seized the vessel . . . and used the incident for a political attack upon Robert Livingston." ${ }^{26}$ John did not assume control of the Livingston family business but instead embarked upon a military career that lasted until his death in 1720 . John had no children by either of his wives. As a

${ }^{26}$ Leder, Robert Livingston's Sons, 242. 
result, Philip Livingston became primary heir to the Livingston fortune at the age of $34{ }^{27}$

Philip, unlike his brothers, appeared to cause his parents little concern and, though trained in law, became a significant merchant, international trader and politician, serving in various Albany posts including councilman and mayor. Philip apparently inherited the traits of his hardworking parents, for "few could rival him in combining the careers of lawyer, landlord, foreign and domestic merchant, politician, and iron manufacturer." ${ }^{28}$ In May of 1721 , he wrote, "In case mother needs any goods... please summon such from me. Will give her a reasonable buy." ${ }^{29}$ In November of 1722, Philip, residing at Albany, wrote Alida, "per your order have sold the animals . . the sale is enclosed herewith."30 Philip assumed a special responsibility for his mother, both because of his reliability and because his home in Albany placed him geographically closer to the manor than his siblings. In June of 1724 , Philip arranged for his mother to travel to New York City to visit her husband at Robert's request. Philip's many letters to his mother portray the extent of his devotion, as well as a strong similarity to her personality. In May of 1726, he wrote Alida that he was returning skins that she

${ }^{27}$ Livingston, The Livingstons of Livingston Manor, 132-138. John Livingston rose to the rank of Colonel prior to his death in 1713.

${ }^{28}$ Kim, Landlord and Tenant, 147-149; Kierner, Traders and Gentlefolk, 64-66.

${ }^{29}$ Philip Livingston to Alida Livingston, 21 May 1721. Philip appeared to have a particularly close relationship with Alida, possibly because his residence was close to the manor. This letter was written from Philip to his mother, though his writing style is awkward.

${ }^{30}$ Philip Livingston to Alida Livingston, November 1722 (letter undated) 
had sent to him that were of poor quality. ${ }^{31}$ In another letter, he stated, "have received the package with bearskins and shaggy deer skins, will look them over today and write you per return mail how I found them and credit father for the value.. ${ }^{32}$ Like Alida, Philip placed a high priority on business and spared no mercy when he received faulty goods - even from his mother.

Robert, Jr., the Livingston's third son, sailed to Europe aboard the Caledonia in October of 1699 at the tender age of 11 to receive training that his parents hoped would result in a lucrative law career. As was common in upper class families, Robert, Jr. resided in Scotland with his uncles, William and James, until their deaths during the summer of 1700 . Then, Barbara Miller, Robert Livingston's sister, assumed the responsibility for Robert, Jr's education. In January of 1700 , she wrote her brother regarding his son's enrollment at a local Latin school. Barbara Miller's daughter, Janet, made sure to let her uncle know that Robert Jr. was very popular in town, owing to his status as a settler in New England. In a portent of things to come, Miller noted, "he loves to be fine and to have his things genteel." ${ }^{33}$

Robert completed his education in London. In May of 1705, Robert wrote to Fitz-John Winthrop of Connecticut, "I...design God willing to goe for Scotland

${ }^{31}$ Philip Livingston to Alida Livingston, 10 May 1726.

${ }^{32}$ Philip Livingston to Alida Livingston, 3 May 1726.

33 LRMSS, Barbara Miller to Robert Livingston from Edinburgh, Scotland January 11, 1700; Livingston, The Livingstons, 146-147. Livingston notes two letters on this page, claiming the first is "still in existence." Livingston had access to family letters, some of which are unavailable today. There is no reason to dispute their validity. 
speedily \& fetch up my son, who is there at ye Colledge." ${ }^{34}$ In 1710 Robert returned to New York and began what would become a very difficult undertaking - the establishment of a lucrative law practice in colonial New York. It was not until 1717, after a series of failed attempts, that Robert, Jr. achieved a8 modicum of success in the field of law. In November of that year he also married Margaret Howarden, the daughter of a wealthy New York merchant. Alida remained surprisingly quiet about the marriage. Two months prior to the wedding, she advised her husband to "let him go ahead perhaps she will make a good wife and God I hope will bless him." A few days later, she commented, "I don't know what to counsel Robbert he has to do as he pleases." ${ }^{35}$

Regardless of his age and marital status, Robert, Jr. still had to answer to his no-nonsense parents. In 1722, the elder Livingston poured out his frustrations about Robert, Jr. in a letter to his wife, noting "our son Robert is not willing to pay ... for house-rent, so that I am at odds everywhere. He is very ungrateful and wants to extort everything from me, but his hopes will be deceived and it will not be to his profit." ${ }^{36}$ Though Robert eventually managed to regain his parent's favor - largely through his successful involvement in colonial trade - his disappointing behavior cast a pall over the Livingston household and embarrassed his parents.

34 Winthrop Papers, 291-293; Robert Livingston to Fitz-John Winthrop, May 7 , 1705.

35 Alida Livingston to Robert Livingston, 12 September 1717; 15 September 1717.

${ }^{36}$ Robert Livingston to Alida Livingston, 8 June 1722. Robert, Jr. also participated in New York commerce, as did his brothers, Philip and Gilbert. 
Despite Robert and Alida's best intentions, sometimes the Livingston children made decisions outside the parameters of their parents' straight-laced values. The Livingstons fourth son, Gilbert, caused his parents much grief throughout his life. As the couple's fourth male heir, Gilbert was destined by his parents to the ministry rather than business. Gilbert, however, had other ideas and as a young adult embarked on a career of commerce. ${ }^{37}$ Shortly afterward he shocked Robert and Alida with the news of his impending marriage to Cornelia Beekman. Robert, uncomfortable with the apparent hastiness of the nuptials, claimed "I was not willing to permit the marriage by any means until I was sure of what the daughter would have with her." ${ }^{38}$ Having accumulated wealth and some level of prestige by 1711 , Robert and Alida feared their son might not enter into a profitable marriage, and even worse, that the couple might wed in an inappropriately hasty manner. This attitude was common during the colonial period, both in Europe and the colonies. Lawrence Stones notes that wealthier, more literate European families compelled, "their children to marry persons selected for them on strictly economic or political grounds." ${ }^{39}$ Cornelia's financial

${ }^{37}$ Lawrence Stone, The Family, Sex and Marriage in England 1500-1800 (New York: Harper \& Row, 1977), 447. According to Stone, it was common for members of the merchant or upper classes to "exercise considerable control over the career choices of their sons." Most of these families destined their sons to careers in "the Church, the law and medicine." The first son, John, was designated as primary heir in accordance with the English practice of primogeniture.

${ }^{38}$ Robert Livingston to Alida Livingston, 5 November 1711; Kierner, 60. Kierner notes that Gilbert not only married well but was able to live off of his wife's "patrimony" after becoming embroiled in serious financial problems.

${ }^{39}$ Stone, 499. 
assets finally earned the Livingstons' approval and the couple married later that same year. Unfortunately, the family's problems with Gilbert were just beginning.

In September of 1721, Gilbert wrote to his father regarding serious financial woes that had resulted in his inability to purchase a good piece of land. Gilbert requested his parent's assistance in the procurement of both land and suitable employment. The following spring - when Gilbert was 32 years of age Robert wrote to Alida from New York City regarding their son's most recent escapade. "No sooner had I reached the shore than Moses Levy accosted me... our Gilbert owed him $£ 70$ and that the time to pay had appeared ... The Sheriff has arrested him for $£ 50$ from Morris and taken his word for his appearance...I have written him to hide, for as soon as he comes here he will be put into prison.. ${ }^{40}$ Eleven days later, Robert wrote that in disregard of his warnings, Gilbert "resolves to come. What his views are I cannot understand."41 Though the Livingston parents obviously resolved to teach their children the lessons of life through "tough love," the dire necessity of Gilbert's situation demanded a response from his family. Robert, in support of his son, had regrettably signed as guarantor on one of Gilbert's debts, making him personally accountable for Gilbert's financial improprieties. On June 8 he informed his wife:

Our son Gilbert is here in order to try to sell his lots and to come to terms with his creditors as well as he can, with which I'm helping

${ }^{40}$ Gilbert Livingston to Robert Livingston, 14 September 1721; Robert Livingston to Alida Livingston, 19 May 1722

${ }^{41}$ Robert Livingston to Alida Livingston, 30 May 1722 

completely

him daily. [I] will have to give him the Naskagioene bowery to pay off the debt that I am guarantor of, plus his other debts. The debts that he has are inexpressible, and what he has done with the money is unimaginable . . I persist in my intended resolution to do nothing more than I have done, in no way." 42

Letters between the couple in the following weeks reveal that, with Alida's approval, Robert transferred the previously mentioned property to his son. Unfortunately, economic problems in the colony made it difficult for Gilbert to sell his properties, and by June 19 he had sold but one lot. On June 13, 1722, Robert reported that Gilbert had sold $£ 440$ worth of property, but was in trouble due to a title dispute and "dare not go outside." ${ }^{43}$ In desperation Robert and Alida arranged for their son, Philip, to hold land at Saratoga on his brother's behalf. Because of his successive financial disasters, Gilbert gained only a farm at Canastoga in the codicil to his father's will dated that same year. His other inheritances were either split amongst all his siblings or sold to pay off his numerous debts. ${ }^{44}$ Though Gilbert was obviously loved deeply by his parents, the couple treated their wayward son in a manner consistent with their business practices. Gilbert had made a mistake, and, though his parents could afford to cover for him, they chose instead to make him responsible for his circumstances.

Fortunately for the Livingstons, daughters Margaret and Joanna caused their parents less anxiety than their brothers. In 1698, Alida conveyed to her

\footnotetext{
${ }^{42}$ Robert Livingston to Alida Livingston, 8 June 1722.

${ }^{43}$ Robert Livingston to Alida Livingston, 13 June 1722.

${ }^{44}$ Codicil to Robert Livingston's will, 22 September 1722.
} 
husband "Our daughter Margaret now goes off to have her bonnets made...she expects a new dress from you. ${ }^{45}$ Margaret seems to have provided her parents with little reason for dismay, at least during her childhood years. Her needs were that of any young girl of the time. As Margaret grew to adulthood, however, her choice of a spouse certainly left much to be desired. Samuel Vetch, a friend of Margaret's eldest brother, John, and a distant relative of the Livingston family, caught Margaret's eye during a visit to the manor. Robert Livingston's brother, William, wrote a missive from Scotland, warning his brother and sister-in-law that the match was not a good choice. Vetch was known for his financial schemes and was not, in the opinion of Margaret's uncle, a sound choice for a mate. The Livingston's Scottish cousin, Janet Miller, also begged the family not to allow the wedding as "I should be ashamed to let any here know that your daughter should entertain such a man who is hated by all his country ... if I can do anything that may prevent her ruin I have gained my end. ${ }^{46}$ Vetch was, indeed, the target of much animosity in his homeland. In 1698 Vetch had participated in a plan to establish a colony at the Isthmus of Darien in Central America. The undertaking, sponsored by the Darien Company, failed because of Spanish attacks and the efforts of the English to block relief ships from reaching the colony. When the sick and wretched survivors, Vetch among them, reached New York, Richard Coote,

${ }^{45}$ Alida Livingston to Robert Livingston, 13 June 1698.

${ }^{46}$ William Livingston to Robert Livingston,30 March 1700. Janet Miller to Robert Livingston, December 20, 1700. G.M. Waller, Samuel Vetch: Colonial Enterpriser (Chapel Hill: The University of North Carolina Press, 1960), 44-45. Janet Miller's letter is difficult to read due to her phonetic spelling. The letter reads, "I shoud be ashamed to let any hier know that your Doughter should entertain such a man whoe is haeted by al his country and that for his evil deads." 
$1^{\text {st }}$ Earl of Bellomont and Governor of New York, permitted them to stay, against the British Ministry's orders. As one of the organizers of the Darien Company, Scottish citizens found it suspicious that Vetch chose to stay in New York with the company's ship, the Caledonia, and its remaining cargo. Scottish investors were furious about the Darien Company's disaster, as Scottish citizens of various occupations and status had invested in the venture, from "the minimum one hundred pounds to the maximum three thousand a total of four hundred thousand pounds." This amount, which has been subject to numerous estimates, was "estimated to be at least half of, or possibly more than, the total investment capital...available at the time in the whole of Scotland." ${ }^{47}$

Fortunately for Margaret, Samuel Vetch also had positive connections with several members of the Livingston family. Samuel's father, William Vetch, had become a minister at the prompting of Robert Livingston's father, John. When Samuel was baptized in December of 1668, Robert Livingston's brother William, "minister at Ancrum," was present, though he later opposed Vetch's marriage plans. Vetch had fortunately become close friends with his cousin, John, Margaret's older brother, and frequently visited Livingston Manor. Like his father-in-law, Samuel Vetch trusted that family relationships and a promising future would back his suit. Margaret, seventeen years of age, caught Vetch's eye and John Livingston became the bearer of many letters between the couple. On December 20, 1700, Governor Bellomont issued a marriage license to the couple. Fortunately for Vetch, Janet Miller's letter was not received prior to their

${ }^{47}$ Waller, Samuel Vetch, 16. 
nuptials. Though Samuel Vetch did not immediately receive a dowry from the Livingstons, they did give the couple a home and lot in New York City, purported to be one of the finest on the waterfront. ${ }^{48}$

Like Alida, Margaret Vetch was frequently alone during her husband's travels. In 1701, Samuel Vetch and John Livingston embarked on a trading venture to Newfoundland on the Mary, named after John's beloved wife. The venture forced Margaret to reside at Livingston Manor while awaiting her husband's return to New York. Vetch had respectfully requested that the Livingstons care for Margaret during his absence, as he feared she was "too much given to MeLanckoly." Margaret's "Melanckoly" was most likely due to her advanced state of pregnancy. A month later, she lamented to her mother, "I am very alone." Margaret frequently visited the manor and mother and daughter both wrote, and exchanged goods, on a regular basis. Shortly after her marriage, Margaret thanked her mother for, " . . . cotton goods and the small barrel of eggs there is not an egg to be gotten here for any money." 49 "Here" was the waterfront house in New York City.

Margaret gave birth to a healthy baby girl, Alida Vetch, in December of $1701 .^{50}$ Her joy was short lived, however. John and Samuel's second trip ended

${ }^{48}$ Ibid, 6, 41-46; The Livingstons of Livingston Manor, 542. Waller notes that a letter written by Margaret dated November 24, 1700 was signed with her married name. The author speculates that Bellomont's license merely formalized a wedding that had already taken place.

${ }^{49}$ Margaret Vetch to Alida Livingston, 13 October 1701.

${ }^{50}$ Samuel Vetch to Alida Livingston from New York, 8 September 1701; to Robert Livingston from New London, Connecticu,t 16 September 1701, LRMSS. Governor Bellomont died unexpectedly while lieutenant-governor Nanfan was in Barbados. The 
in disaster for the Vetches. A storm disrupted the voyage, and, though Vetch miraculously survived, so did the proof of his illegal activities in trading with Newfoundland. The Vetches were publicly embarrassed and no doubt the Livingstons faced their fair share of scorn on their son-in-law's behalf. The question that must be asked is why the Livingstons permitted their daughter's marriage to a notorious troublemaker. While Vetch stood to gain status and worldly goods as part of Margaret's dowry, the Livingston's eldest daughter had little to gain from a lifetime with Vetch. Despite his faults, however, Vetch generally supported his in-laws and frequently shared information that influenced the Livingston's financial matters. Likewise, in August of 1716, Vetch wrote his father-in-law from London and reprimanded him for not answering Margaret's letters or offering her financial support. ${ }^{51}$ Correspondence continued to flow between Margaret Livingston Vetch and her mother, but information regarding Alida's opinion of her son-in-law is not available. However, the similarities of Margaret and her mother's lives cannot be ignored. Like her mother, Margaret Vetch spent much time alone as a result of her husband's business dealings and knew the anguish this separation caused. Samuel Vetch's frequent absences also required Margaret to import and export goods on her husband's behalf, both during their lives together and after Vetch's death in $1732 .{ }^{52}$ Fortunately,

political chaos and trade restrictions in New York prompted John Livingston and Samuel Vetch to engage in illicit trade with Newfoundland, from which they brought "brandy, claret and wines" among other items.

${ }^{51}$ Samuel Vetch to Robert Livingston, 28 December 1713; 7 June 1714; 25 August 1716, LRMSS.

${ }^{52}$ Kierner, From Entrepreneurs to Ornaments, 342. 
Margaret Livingston Vetch was well acquainted with the nature of business and managed, like her mother, to insure her family's financial wellbeing. ${ }^{53}$

As the Livingston children grew and established their own families, they remained in close contact with their parents. The children's correspondence reveals a deep devotion to their parents, a devotion also shared by the Livingston grandchildren. Though the couple's eldest son, John, died before producing a Livingston heir, his brothers and sisters provided their parents with a number of grandchildren. Philip Livingston had eleven children; Robert Livingston, Jr. one child, and Gilbert Livingston fifteen. The Livingston's eldest daughter, Margaret Vetch, gave birth to four children, two of whom survived. Margaret and Samuel Vetch named their eldest child Alida. Joanna and her husband, Cornelius G. Van Horne, also named a daughter after the Livingston matriarch. Both daughters displayed their affection for their mother not only in the naming of their children, but also in the letters they exchanged on a regular basis. ${ }^{54}$

When Robert and Alida visited Philip's family in April of 1711, daughter Joanna, still young and living at Livingston Manor, wrote to her mother, "I long to

${ }^{53}$ Ibid, 342. Kierner notes that although Margaret Livingston Vetch imported and exported items for more than 30 years during the early eighteenth century, this was not seen as unusual "but, rather, mentioned casually to indicate that she did nothing especially unusual." Like Laurel Thatcher Ulrich's "deputy husbands," Margaret was well acquainted with her husband's business affairs.

${ }^{54}$ An excellent Livingston family tree is available in the appendix of Cynthia Kierner's Traders and Gentlefolk. The marriage of Joanna Livingston to Cornelius G. Van Horne is noted in The Clarksons of New York: A Sketch Volume I (New York: Bradstreet Press, 1875), 234. Joanna and her husband had four children, but none of the children survived beyond the age of five. Joanna's final pregnancy ended in a stillbirth in 1733 and Joanna died the same year. 
see you here. I do not want to be alone here...I cannot write you anything else but that I wished you were here." ${ }^{55}$ Joanna married Cornelius Gerrit van Horne in 1720, after a relationship with Henry Beekman ended in failure in 1717. Beekman, related to Gilbert Livingston by birth, dared to approach the Livingston matriarch during one of Robert's absences from the manor. The resulting confrontation likely left Mr. Beekman weak in the knees. Alida regaled her husband with the details of the untimely visit. "Henderick Beekman was here and I asked him what his business was here he said for my daughter I said if he came as Ghijsbert's brother-in-law he was welcome if he came for my daughter [it] would never happen then he could save himself the trouble." Gerrit Van Horne fared better, and Joanna maintained a positive relationship with her parents throughout her marriage. In 1723 she wrote, "I flatter myself with the thought to see mother here toward the end of May." In 1724 she again wrote to Alida, "I hoped that mother would come down but now I do not expect it knowing from father's letter that there is much work at the manor." In the letter, Joanna mentioned her father's impending visit and her "time of need." Joanna, who gave birth that same year, undoubtedly wished for her mother's presence during her pregnancy. ${ }^{56}$ As the youngest child, Joanna appeared to have an especially

55 Joanna Livingston to Alida Livingston, 13 April 1711, from the Manor of Livingston. Joanna would have been about 17 years of age, and the youngest child remaining at home due to the death of her younger sister Catharina, in 1699.

${ }^{56}$ Joanna van Horne to Alida Livingston, 21 April 1724. 
close relationship with her mother. Even Philip, in a letter to his mother dated June 11, 1724, noted, "Sister van Horne longs to see you." ${ }^{57}$

Considering Alida Livingston's wealth and character, the women and men who became husbands and wives of the Livingston children must have experienced apprehension about their future mother-in-law. However, once they had gained Alida's approval, the family's letters reveal that the Livingston in-laws were treated with the same affection as Robert and Alida's own children. It was, in fact, Dutch custom to accept an in-law with the same affection as a family member. Gilbert's wife, Cornelia Beekman Livingston, wrote tenderly of her mother-in-law, referring to her as "revered mother." ${ }^{58}$ In September of 1711, Robert Livingston wrote to his wife from New York in reference to their daughterin-law, Mary, who had undergone an operation "for the cancer in the breast this forenoon . . . she is still full of pain, but the doctors say things will be in a good way." ${ }^{\text {"9 }}$ On September 15, 1711, Robert reported, "Your daughter Mary is looking well and sitting up and starts getting an appetite." ${ }^{\text {60 }}$ Sadly, Robert's letter to Alida dated August 22, 1712, bore sad news regarding Mary's health. "I hear his [John's] wife has been operated upon 3 times in New London," concluding that Mary's condition was hopeless. Both Robert and Alida expressed concern

${ }^{57}$ Joanna van Horne to Alida Livingston, 11 June, 1724

${ }^{58}$ Cornelia Beekman Livingston to Alida Livingston, 9 May 1712. Cornelia Beekman married Gilbert Livingston, Robert and Alida's youngest surviving son, in 1711.

${ }^{59}$ Robert to Alida, 7 September 1711. Mary Winthrop Livingston was the first wife of John Livingston and had obviously earned the devotion of Robert, Alida and her sisters-in-law. York.

${ }^{60}$ Robert Livingston to Alida Livingston, 15 September 1711, written from New 
over their daughter-in-law's health, and Robert's letters suggest that he frequently visited Mary during her illness and that both he and Alida cared deeply for her. The couple was saddened when Mary Livingston died shortly thereafter. Alida Schuyler left a rare legacy for her children. Though colonial society placed a higher priority on women's maternal accomplishments than their business ventures, Alida Livingston expertly fulfilled the role of mother well while also embodying the traits necessary for worldly success. As the Livingston children grew, Alida included them in the family business. The majority of the children's correspondence contains references to trade goods that traveled back and forth between the adult Livingston offspring and Robert and Alida. ${ }^{61}$ When a Livingston child failed to meet their mother's expectations - either in business or in life - Alida hastily informed the offender of his or her wrongdoing. Despite her penchant for sometimes painful forthrightness, the Livingston children, their spouses and grandchildren, obviously adored the Livingston matriarch. Though little of Alida's correspondence with her grandchildren exists, the few surviving letters indicate that her grandchildren were frequent visitors at Livingston Manor. In May of 1721, Philip requested that his mother send his sons back home from their visit. When Philip's sons left for school in New Haven in May of 1726, Philip wrote, "My two sons Peter and John are to go this week to New Haven to school." One week later, Philip informed his mother that the boys would be

61 The Livingston children frequently exchanged food items, clothing and trade goods such as furs with their parents. In October of 1701, Margaret Vetch wrote, "I send mother ten oranges, a jacket and father's winter frock and a pair of shoes and scarf." Items that could not be attained in Albany were often sent to the Livingston parents via one of their children. Margaret Vetch to Alida, 13 October 1701. 
stopping by to see her before they left for New Haven. ${ }^{62}$ The Livingston's granddaughters also wrote to their grandmother with obvious affection, indicating that they maintained a close relationship with their revered grandmother. In a letter dated February of 1723, Margaret Vetch thanked Alida for caring for her granddaughter while the Vetches visited London. Correspondence between Alida Vetch and her grandmother in 1724 indicates a close relationship, as Alida Vetch shared her desire to visit her grandparents as well as conveying personal information regarding a marriage proposal she had received. ${ }^{63}$

For Alida Livingston, the seemingly endless round of childbirth, childrearing, trading and home management must have often seemed mundane and tedious. Like her contemporaries, she was simply doing what had to be done in order for her family to survive. For the Livingston children and grandchildren, however, Alida's influence cannot be minimized. Almost fifty years after Alida's death, a revolution that threatened the very existence of the colonies would usher in a new era for the women of the newly formed United States of America. The desperation of colonial life that drove Alida Livingston to succeed as a wife, mother and businesswoman would be replaced by societal expectations that women become more "ornamental" than functional. Alida's

${ }^{62}$ Philip Livingston to Alida Livingston, 10 May 1726, written from Albany. Philip's children appeared to have a close relationship with their grandmother, possibly because of their close location to Livingston Manor and Philip's role as the primary heir after his brother's death.

${ }^{63}$ Margaret Livingston Vetch to Alida, 22 February 1723; Alida Vetch to Alida Livingston, 25 March 1724; 30 May 1724. Margaret expressed concern that London would be unsafe for her daughter Alida, due to the spread of smallpox there. It should be noted that each of the surviving Livingston children named a daughter Alida after their mother, with the exception of Robert, Jr. who had no daughters. 
granddaughters and great granddaughters would reach adulthood in a world that defined a woman by her social graces and beauty rather than the hardworking characteristics embraced by the Livingston parents and their ancestors. ${ }^{64}$ Despite these changes, Alida Livingston's legacy insured that her sons, daughters and grandchildren could sensibly face whatever changes the future brought. The more than 160,000 acres that Alida helped her husband to amass during their marriage formed the foundation on which future generations of Livingstons would build. Through the years the Livingston family tree expanded to include merchants, politicians, and a signer of the Declaration of Independence. Though the daily hardships of frontier life often overwhelmed the hardworking Alida Livingston, the fruits of her labor provided the burgeoning colony of New York with many of its finest citizens.

${ }^{64}$ Kierner, From Entrepreneurs to Ornaments, 336-338. 


\section{AFTERWORD}

In 1726, Robert Livingston's "dear hart" was laid to rest in the family vault at Livingston Manor. During her lifetime Alida Livingston constantly struggled to balance work and family interests, which, due to the Livingston merchant empire, required a blending of both. She was never an independent businesswoman under English law, and none of her existing correspondence reveals her thoughts on women's roles in colonial New York. In reality, it is doubtful that she had the time to ponder such questions - building a family empire was hard work.

The Livingston legacy that Alida and Robert Livingston strove to build was radically transformed during the eighteenth century, beginning with Robert's death in $1728 .{ }^{1}$ The Livingston children inherited their parents' extensive properties and financial resources upon Robert and Alida's deaths.

Unfortunately, not all of the Livingston heirs were as responsible as their hardworking parents, nor did they maintain congenial relationships with their siblings throughout their adult years. In fact, the Livingston children appeared to place a higher priority on protecting the family fortune than on maintaining sibling relationships. Margaret and Joanna's distrust of John's second wife, jealousy over their inheritances and Gilbert's ongoing irresponsibility made preservation of Robert and Alida's legacy difficult. Under the English system of primogeniture,

1 Leder, Robert Livingston, 291; Livingston, The Livingstons of Livingston Manor, 541. There is some discrepancy regarding the date of Alida's death. Edwin Brockholst Livingston notes her death in 1729, and other historians, such as Kierner, date it in 1726. Livingston, The Livingstons of Livingston Manor, 541; Kierner, Traders and Gentlefolk, 254. 
Robert Livingston willed the manor to his eldest son, John, and, upon John's untimely death, to Philip. ${ }^{2}$ His death left Philip, Gilbert, Robert, Margaret and Joanna to preserve the manor. Despite their inheritances, Joanna and Margaret neither carried on the family name nor resided at the manor during their adult lives. Joanna appears to have retreated from the Livingston family during her married years. She died in 1733 prior to her fortieth birthday.

Margaret Livingston Vetch also distanced herself from the Livingston family, if only temporarily. Her husband, Samuel Vetch, continued to participate in illegal trading schemes and in 1706 Massachusetts Bay charged him with, "Illegal trade with the ffrench Kings Subjects and vasals, the Open and Declared Enemys of her Majesties Government..." His participation in Britain's 1710 attempt to conquer Annapolis Royal in Nova Scotia earned him England's goodwill and the colony's first governorship. ${ }^{3}$ He served as governor until 1717 , though Francis Nichollson charged that he mismanaged funds as governor and temporarily replaced him. A letter from Margaret to her father in October of 1717 noted the loss of Samuel Vetch's position at Annapolis Royal and her plans to travel to London with her children to reunite with her husband. Margaret and the

2 Brandt, An American Aristocracy, 70-72. Brandt sums up the life of eldest son John Livingston in her truthful, if somewhat blunt, style: "...in 1720, at the age of 40, John provided his final diversion by dying."

3 "An Act for the Punishment of Samuel Vetch Esqr for High Misdemeanor," in The Acts and Resolves, Public and Private, of the Province of Massachusetts Bay: To Which Are Prefixed The Charters of the Province with Historical and Explanatory Notes, and an Appendix, Volume VI (Boston: Wright \& Potter, 1896), 62. For information on Vetch's 1710 expedition see John G. Reid, The "Conquest" of Acadia, 1710: Imperial, Colonial, and Aboriginal Constructions (Toronto: University of Toronto Press, Inc., 2004). 
couple's only son, William [Billy] eventually sailed to London to join Vetch, leaving behind their daughter, the sixteen-year-old Alida. To pay for the trip, Margaret sold many of her household goods, as money was often scarce in the Vetch household. ${ }^{4}$ Life in Britain was difficult for Margaret and Billy, as Samuel Vetch continued to accrue unpaid debts and died in a London debtor's prison in 1732. ${ }^{5}$ Margaret returned to New York after his death but her parents had died and she had not maintained close relationships with her male siblings. Though the basis for the Livingston siblings' differences is uncertain, a 1716 letter from Philip Livingston to his brother, Robert, indicates that Margaret and Philip had experienced conflict while doing business. In a letter to his father-in-law that same year, Samuel Vetch scolded the elder Livingston for not offering financial support to Margaret in his absence. These issues most likely contributed to the strained relationship between the male siblings and Margaret, as business and finances were a priority in the Livingston children's lives. ${ }^{6}$

Fortunately, Alida had raised Margaret with a solid understanding of the finer points of trade, and she spent the remainder of her life sporadically

${ }^{4}$ Margaret Vetch to Robert Livingston, 15 October 1717; 21 October 1717; 4 November 1717, LRMSS. In An American Aristocracy: The Livingstons, Clare Brandt states that Margaret sailed to London "without a word to Robert and Alida...," though three letters from Margaret to her father regarding her plans for the upcoming trip have survived. Margaret's letter of 21 October stated that she planned to take both Billy and Alida Vetch to London, but in her letter of 4 November notes that, due to safety issues, she decided to leave her daughter at home.

${ }^{5}$ W. Stewart Wallace, ed., The Encyclopedia of Canada, Vol. VI, (Toronto, University Associates of Canada, 1948), 237.

${ }^{6}$ Philip Livingston to Robert Livingston, 23 April 1716; Samuel Vetch to Robert Livingston, 25 August 1716, LRMSS. 
importing and exporting goods as need and opportunity occurred. Her trading commodities included dry goods, rum, candles, silk, lace, furs and wine. The Livingston family name and extensive trade network certainly benefitted Margaret as noted in her 1754 account with cousin Robert Livingston, Jr. for silks and lace. Other family connections in London, Southern Europe and the West Indies helped Margaret Vetch to survive the financial strain that resulted from her marriage. $^{7}$

Philip Livingston inherited the manor, responsibility for his brother Gilbert's debts, and the enormous task of maintaining the family's name and social status in Albany. Unlike his brothers, Philip had acquired his parent's work ethics and devotion to the family business. Under his direction, the manor, and the Livingston family's trade empire, expanded exponentially. Five of his six sons became successful merchants, further extending the family's trade connections through apprenticeships in Europe and Jamaica. His youngest son, William, rejected mercantilism for law. The family most certainly forgave him, though, as he became one of New York's most prosperous attorneys and governor of the state of New Jersey. With a son in every port, so to speak, Philip dominated trade at every level. Like their grandparents, Philip Livingston's heirs also owned and sold slaves. In 1760 grandson Philip sold "one Negro wench named Jen about Twenty four Years Old \& also a negro Girl named Hannah" to Rieneer Van

\footnotetext{
${ }^{7}$ Robert Livingston, Jr., "Account of Margaret Vetch re: blue and yellow silk, and lace." 1754/09-1754/11, LRMSS; Serena R. Zabin, Dangerous Economies: Status and Commerce in Imperial New York (Philadelphia: University of Pennsylvania Press, 2009), 42-43. Zabin compares Vetch's sporadic trading ventures to those of Ann Elizabeth Schuyler and Mary Alexander, referring to Vetch as "another middling merchant."
} 
Giesen of New Jersey for "One Hundred Pounds Currant money ..." His son, also named Philip, witnessed the transaction. ${ }^{8}$

During the 1740s, Philip established an ironworks at Livingston Manor. Sally A. Bottiggi observes that the Livingstons were in an exceptional position. The steep cost of entering the ironmaking industry usually required several investors and therefore, a division of the assets. Philip's large inheritance, however, permitted him to maintain sole ownership of the iron making industry at Ancram. Philip and his family not only kept the monetary compensation for themselves, they also used their family stores to provide goods to the iron workers and transported them to market via the family's ships or the roads of Livingston Manor. ${ }^{9}$ Alida Livingston's legacy certainly lived on through Philip, whose practicality and harshness may not have earned him many friends but did sustain the Livingston fortune for the next generation. Upon his death, Philip bequeathed to his eldest son, Robert, Jr.,

all my lands and tenements in the manor of Livingston, with the grist mills and saw mills, furnace, forge and all buildings and premises, and improvements I have made on the manor, which are very considerable... 3 negroes, 12 horses, 6 geldings, 6 mares, 6 cows, 6 sheep, 6 hogs, and my chariot and my gold watch.

${ }^{8}$ Philip Livingston, "Bill of sale for two slaves sold to Rieneer Van Giesen," 29 November 1760.

${ }^{9}$ Sally A. Bottiggi, "An Iron Experiment: The Livingston Ironworks and the Colonial Iron Industry 1743-1790," in Richard T. Wiles, ed., The Livingston Legacy: Three Centuries of American History (New York: Bard College, 1987), 283-294. The name Ancram was derived from Robert Livingston's home town in Scotland. 
Philip also left almost 20,000 acres each to the remainder of his children, and the Livingston legacy of land and prosperity continued. ${ }^{10}$

Gilbert Livingston relied on the support of his wife's family and managed to spend his remaining years behaving in a manner worthy of a Livingston, despite his inclination toward idleness. Because of his propensity to accumulate debts with disregard for his inability to repay them, his father's final will dictated that any income garnered from the family's Saratoga farm be held under the trusteeship of his brother, Philip. It is doubtful this arrangement promoted brotherly affection between Gilbert and Philip, but even in death the elder Livingstons managed to maintain their public façade by protecting the family name from Gilbert's many indiscretions. Gilbert's will of December 1745 stands in sharp contrast to that of his brother, Philip. The will provided only $£ 3,000$ for "for my ten younger children" and another $£ 1,000$ for his eldest son and heir, along with unnamed properties. The will stated that the small cash inheritance came from the estate of Gilbert's father-in-law. Unfortunately, Gilbert's children followed in their father's footsteps. ${ }^{11}$

Like Gilbert, the Livingston's youngest son, Robert, continued his quest for gracious living, yet initially spurned the hard work necessary to maintain it. In 1714 Robert took up residence with Philip and his wife, Catrina, in their Albany

${ }^{10}$ Abstracts of Wills on File in the Surrogate's Office, City of New York Volume IV 1744-1753 with Letters of Administration Granted 1745-1753 (New York: New York Historical Society, 1895), 230-232; Kierner, Traders and Gentlefolk, 79-85, 88. In a chapter titled, "The Family Land," Kierner reveals the legacy of land inherited by each generation of the Livingston family.

${ }^{11}$ Abstracts of Wills, Volume IV, 87-88; Brandt, An American Arisocracy, 77. 
home. Catrina, who perhaps shared more in common with her mother-in-law than did the Livingston children, possessed little patience and was a formidable woman. When she attempted to negotiate a romance between Robert and his cousin, Myndert Schuyler, Robert protested the affair, noting the woman's "silliness" for which he "should be obliged to blush as often as she was in Company." Catrina, angry and embarrassed, informed him that if he wished to leave, "I might do that when I pleased." Robert did move, bringing unwanted and negative - attention to the Livingston family squabble in Albany. Both Robert and Philip quickly wrote letters to their father to explain their side of the incident, which had resulted in Catrina's refusal to speak to her brother-in-law. ${ }^{12}$ Robert finally redeemed himself - in the eyes of the community and the history of the Livingston family - by abandoning his law practice to follow in his father's mercantile footsteps. Robert succeeded as a trader and built a vast estate known as Clermont Manor on the 13,000 acres granted him from Philip's manor holdings by his father. Why Robert Livingston chose to leave one negligent son virtually nothing and the other a sizeable estate cannot be verified, though family history claims that Robert foiled an Indian conspiracy to murder the family in their sleep, and was thus rewarded for his good deed by his father. ${ }^{13}$ Robert's son, known historically as "Robert the Judge," served on the Supreme Court of New York, as Judge of the Admiralty Court, and fathered "Robert the Chancellor,"

12 Robert Livingston to Robert Livingston, 25 January 1714; Philip Livingston to Robert Livingston, 25 January 1714. Both sons wrote to their father on the same day. The embarrassment to the Livingston family warranted a prompt explanation on both sides.

${ }^{13}$ Kierner, Traders and Gentlefolk, 57-58. 
Robert and Alida's great-grandson who served with Thomas Jefferson and John Adams on the Committee of Five to draft the Declaration of Independence. Among Robert the Chancellor's many notable accomplishments, he administered the oath of office to George Washington at the first presidential inauguration of the United States.

It would be easy to claim that when Alida Schuyler Van Rensselaer became Mrs. Robert Livingston in 1697 she had no idea to what extent her fortune would increase. That would be untrue, however. In the small world of colonial Albany few families could compete financially with the likes of the Schuylers, Van Rensselaers or Courtlandts. The small number of wealthy families who inhabited Albany during the late seventeenth and early eighteenth centuries had little choice but to marry within the confines of the Dutch Reformed religion and, even more importantly, within the confines of their social status. Descendants of these prosperous families intermarried for generations, creating a complex social strata based on inheritance, familial connections and property. From the age of nineteen until her death at the age of seventy-two, Alida strove to duplicate the Schuyler family fortune, hoping to insure her children's rightful place in the upper echelons of New York society. The proof of her success lay in their carefully arranged marriages, vast landholdings and social prominence.

It is likely that the Livingston children and grandchildren's lives of affluence would have astounded the first lady of the manor. During her forty-eight years of marriage Alida's daily life centered on imports, exports and manor sales. She and Robert did not build Livingston Manor to impress their neighbors or to 
establish a country estate. The manor merely provided the land and resources necessary to insure her family's wellbeing in a world where one tragic business transaction could negate years of hard work and sacrifice. She prepared her daughters for the future in much the same way that her mother, Margarita van Slichtenhorst, had trained her: by modeling for them good common sense, work ethics and trading skills. But the world that awaited the Livingston daughters and granddaughters - was changing rapidly. Alida "had been a shrewd and industrious entrepreneur, but her granddaughters were genteel ladies and aspiring belles." ${ }^{14}$ The hardworking women of late seventeenth century New York gave way to the socialites of the eighteenth century, virtually erasing the lifestyle embraced by Alida and her female ancestors.

Historians of early New York have, with few exceptions, virtually ignored the contributions of Dutch businesswomen to the colonial economy from 1674 until the revolutionary period. It has become common to pity these women because as citizens of the twenty-first century it is difficult to fathom the loss of legal freedoms that denied business ownership to women whose ancestors had enjoyed that privilege for generations. As a result, it is easy to assume that because women no longer participated in commerce under the mantle of their own names, their contributions are somehow less worthy or, worse, nonexistent. Alan Taylor's assertion that, "During the early 1660 s about forty-six women conducted commerce in their own names at Beverwyck; none did so in the Albany of 1700 " has been erroneously interpreted as "No women engaged in

\footnotetext{
${ }^{14}$ Kierner, From Entrepreneurs to Ornaments, 336.
} 
Albany's commerce after 1700." This is simply not true. What happened to these forty-six women? Did they cease to trade, or did they simply cease to trade in their own names? Did they become equal business partners with their husbands or children? Even more importantly, to what extent did they function as single entrepreneurs prior to 1674 ? Were businesses registered to women run exclusive of male involvement? Future studies of the businesswomen of New York must include an analysis of this transitional phase. It is my hope that the study of Alida Livingston provides a platform from which to investigate these women who have heretofore been lost to history.

There is no evidence that Alida Livingston ever aspired to the life of an independent businesswoman. She did, however, aspire to make the most of the Livingston name. As the daughter of one of Albany's most prosperous families and the young widow of a wealthy Dutchman, her marriage to a middling Scotsman in 1679 had posed a huge risk. Alida spent her life proving the validity of her choice. Regardless of Robert Livingston's many escapades, she publicly supported him and vigorously defended the family name. She utilized relationships with local tradesmen, family members and even her own children to firmly establish her husband's and children's right to a place in Albany's upper class. These relationships reveal that although economic survival demanded the majority of her attention, she developed loving relationships with her husband, children, grandchildren and sons-and-daughters-in-law. During the eighteenth century, Livingston Manor became the basis of a family dynasty that influenced 
commerce and politics in New York for generations. ${ }^{15}$ Though the manor no longer exists, the Livingston name has remained prominent in the business and political affairs of colonial New York to the twenty-first century. Alida Livingston's life challenges the supposition that English common law practices in New York ended independent business activity by women in that province. It is my hope that this study will open the door to a new understanding of the lives of New York's earliest businesswomen.

15 Kierner, Traders and Gentlefolk: The Livingstons of New York, 1675-1790 (Ithaca: Cornell University Press, 1992), 127. 


\section{Bibliography}

\section{Primary Sources/Collections}

Livingston-Redmond Family Papers, on file at the Gilder-Lehrman Institute of American History, New York City (unpublished)

Abstracts of Wills on File in the Surrogate's Office, City of New York Volume I. New York: New York Historical Society, 1892.

Abstracts of Wills on File in the Surrogate's Office, City of New York Volume IV 1744-1753. New York: New York Historical Society, 1895.

The Acts and Resolves, Public and Private, of the Province of Massachusetts Bay to Which Are Prefixed the Charters of the Province: with Historical and Explanatory Notes, and an Appendix. Boston: Wright \& Potter, 1869.

The Acts and Resolves, Public and Private, of the Province of the Massachusetts Bay: to Which Are Prefixed the Charters of the Province. Boston: Wright \& Potter, Printers to the State, 1896.

Collections of the Massachusetts Historical Society. Vol. III. Sixth. Boston: Massachusetts Historical Society, 1889.

Collections of the New York Historical Society for the Year 1893. New York: Printed for the Society, 1893.

Documents of the Assembly of the State of New-York, Sixty-Seventh Session, 1844, Volume VII. Albany: Carroll and Cook, Printers to the Assembly, 1844.

Fortescue, J.W., ed. Calendar of State Papers, Colonial Series, American and West Indies, 27 October 1697-31 December 1698. London: Mackie \&, LD, 1905.

Hastings, Hugh, ed. Ecclesiastical Records: State of New York. Albany [N.Y.: J.B. Lyon, State Printer, 1901.

Munsell, Joel, ed. Collections on the History of Albany, from Its Discovery to the Present Time, with Notices of Its Public Institutions and Biographical Sketches of Citizens Deceased. Vol. I. Albany: J. Munsell, 1865.

O'Callaghan, E. B. Laws and Ordinances of New Netherland, 1638-1674. Albany: Weed, Parsons and Company, Printers, 1868. 
O'Callaghan, E. B. The Documentary History of the State of New-York; Arranged under Direction of the Hon. Christopher Morgan, Secretary of State. Vol. II. Albany: Weed, Parsons \&, Public Printers, 1849.

O'Callaghan, E. B. The Documentary History of the State of New-York; Arranged under Direction of the Hon. Christopher Morgan, Secretary of State. Vol. III. Albany: Weed, Parsons \&, Public Printers, 1850.

Rensselaer, Kiliaen Van. New York State Library: Van Rensselaer Bowier Manuscripts Being the Letters of Kiliaen Van Rensselaer, 1630-1643, and Other Documents Relating to the Colony of Rensselaerswyck. Transl. and Ed. by A. J. F. Van Laer . . A Albany: University of the State of New York, 1908.

Rensselaer, Maunsell Van. Annals of the Van Rensselaers in the United States. Albany: Charles Van Benthuysen, 1888.

Reynolds, Cuyler. Hudson-Mohawk Genealogical and Family Memoirs: a Record of Achievements of the People of the Hudson and Mohawk Valleys in New York State, Included within the Present Counties of Albany, Rensselaer, Washington, Saratoga, Montgomery, Fulton, Schenectady, Columbia and Greene. New York: Lewis Historical Pub., 1911.

Van Rensselaer, Kiliaen., ed. Van Rensselaer Bowier Manuscripts, Being the Letters of Kiliaen Van Rensselaer, 1630-1643, and Other Documents Relating to the Colony of Rensselaerswyck, Translated and Edited by A. J. F. Van Laer, ... With an Introductory Essay by Nicolaas De Roever, ... . Translated by Mrs. Alan H. Strong. Albany: University of the State of New York, 1908.

Van Rensselaer, Maria. Correspondence of Maria Van Rensselaer, 1669-1689;. Albany: University of the State of New York, 1935.

Stiles, Henry R. The New York Genealogical and Biographical Record. Vol. XXXII. New York: New York Geneaological and Biographical Society, 1901. 


\section{Secondary Sources:}

Barnes, Viola Florence. The Dominion of New England: a Study in British Colonial Policy. New York: F. Ungar Pub., 1960.

Beer, George Louis. British Colonial Policy 1754-1765. Gloucester: Peter Smith, 1958.

Berkin, Carol. First Generations: Women in Colonial America. New York: Hill and Wang, 1996.

Biemer, Linda Briggs. "Business Letters of Alida Schuyler Livingston, 16801726." New York History 63, no. 2 (April 1982): 183-207.

Biemer, Linda Briggs. Women and Property in Colonial New York: the Transition from Dutch to English Law 1643-1727. Ann Arbor, MI: UMI Research Press, 1983.

Bishop, J. Leander, Edwin T. Freedley, and Edward Young, eds. A History of American Manufactures from 1608 to 1860. New York: A. M. Kelly, 1966.

Blackburn, Roderic H., and Ruth Piwonka. Remembrance of Patria: Dutch Arts and Culture in Colonial America, 1609-1776. New York: Produced by the Pub. Center for Cultural Resources for the Albany Institute of History and Art, 1988.

Bonomi, Patricia U. A Factious People: Politics and Society in Colonial New York. New York: Columbia University Press, 1971.

Brandt, Clare. An American Aristocracy: the Livingstons. Garden City, NY: Doubleday, 1986.

Burrows, Edwin G., and Mike Wallace. Gotham: a History of New York City to 1898. New York: Oxford University Press, 1999.

Calhoun, Arthur Wallace. A Social History of the American Family from Colonial times to the Present, by Arthur W. Calhoun, ... Cleveland: A. H. Clark, 1917.

The Clarksons of New York; a Sketch. New York: Bradstreet Press, 1875.

Cobb, Sanford H. The Story of the Palatines: an Episode in Colonial History. New York: G. P. Putnam's Sons, 1897. 
Doddridge, John, and Carrie Chapman Catt, eds. The Lawes Resolutions of Womens Rights, Or, The Lawes Provision for Woemen: a Methodicall Collection of Such Statutes and Customes, with the Cases, Opinions, Arguments and Points of Learning in the Law, as Doe Properly Concerne Women: Together with a Compendious Table, Whereby the Chiefe Matters in This Booke Contained, May Be the More Readily Found. London: Printed by the Assignes of lohn More, Esq., and Are to Be Sold by lohn Grove ..., 1632.

Earle, Alice Morse. Child Life in Colonial Days,. New York: Macmillan Company, 1899.

Earle, Alice Morse. Colonial Days in Old New York. New York: Charles Scribner's Sons, 1896.

Earle, Alice Morse. Home Life in Colonial Days. New York: Macmillan, 1898.

Eberlein, Harold Donaldson., and Cortlandt Van Dyke Hubbard. Historic Houses of the Hudson Valley,. New York: Architectural Book Pub., 1942.

Fabend, Firth Haring. A Dutch Family in the Middle Colonies, 1660-1800. New Brunswick: Rutgers University Press, 1991.

Fernow, Berthold, and Der Veen, Waleyn. Van, eds. The Minutes of the Orphanmasters of New Amsterdam, 1655 to 1663. New York: F.P. Harper, 1902.

Fisher, Sydney George. Men, Women and Manners in Colonial Times. Philadelphia: Lippincott, 1898.

French, John Homer, Ed. Gazetteer of the State of New York. Syracuse, NY: R.P. Smith, 1860.

Frey, Albert Romer. A Dictionary of Numismatic Names, Their Official and Popular Designations. New York: American Numismatic Society, 1917.

Goldsmith, Oliver. The Citizen of the World: Or, Letters from a Chinese Philosopher, Residing in London, to His Friends in the East. Vol. I. London, 1800.

Goodfriend, Joyce. "Writing/Righting Dutch Colonial History." New York History 80, no. 1 (January 1999). 
Grant, Anne MacVicar. Memoirs of an American Lady, with Sketches of Manners and Scenery in America, as They Existed Previous to the Revolution. New York: George Dearborn, 1836.

Griffis, William Elliot. The Story of New Netherland the Dutch in America. Boston: Houghton Mifflin, 1909.

Gronim, Sara Stidstone. Everyday Nature: Knowledge of the Natural World in Colonial New York. New Brunswick, NJ: Rutgers University Press, 2009.

Gundersen, Joan R., and Gwen Victor Gampel. "Married Women's Legal Status in Eighteenth-Century New York and Virginia." The William and Mary Quarterly, Third, 39, no. 1 (January 1982): 114-34.

Hackett, David G. The Rude Hand of Innovation: Religion and Social Order in Albany, New York, 1652-1836. New York: Oxford University Press, 1991.

Harris, Leslie M. In the Shadow of Slavery: African Americans in New York City, 1626-1863. Chicago: University of Chicago Press, 2003.

House, Renée, and John Coakley. Patterns and Portraits: Women in the History of the Reformed Church in America. Grand Rapids, Ml: Eerdmans, 1999.

Jacobs, Jaap, and Herman Wellenreuther. Jacob Leisler's Atlantic World in the Later Seventeenth Century. New Brunswick: Transactions Publishers, 2009.

Jardine, Lisa. Going Dutch: How England Plundered Holland's Glory. New York: Harper, 2008.

Kammen, Michael. Colonial New York: A History. New York: KTO, 1978.

Kierner, Cynthia A. Traders and Gentlefolk: the Livingstons of New York, 16751790. Ithaca: Cornell University Press, 1992.

Kim, Sung Bok. Landlord and Tenant in Colonial New York: Manorial Society, 1664-1775. Chapel Hill: Published for the Institute of Early American History and Culture, Williamsburg, Va., by the University of North Carolina Press, 1978.

Klein, Milton M. The Empire State: a History of New York. Ithaca: Cornell University Press, 2001.

Knittle, Walter Allen. Early Eighteenth Century Palatine Emigration: A British 
Governor Redemption Project to Manufacture Naval Stores. Boston: Geneaological Publishing Company, 1997.

Leder, Lawrence H. Livingston Indian Records 1666-1723. Gettysburg: Pennsylvania Historical Association, 1956.

Leder, Lawrence H. Robert Livingston, 1654-1728, and the Politics of Colonial New York. Chapel Hill: Published for the Institute of Early American History and Culture at Williamsburg, Va., by the University of North Carolina Press, 1961.

Leder, Lawrence H. "Robert Livingston's Sons: Preparation for Futurity." New York History, July 1969.

Leder, Lawrnece H. "The Unorthodox Dominie: Nicholas Van Renssealer." New York History, no. 35 (1954): 166-76.

Livingston, Edwin Brockholst. The Livingstons of Livingston Manor Being the History of That Branch of the Scottish House of Callendar Which Settled in the English Province of New York during the Reign of Charles the Second : and Also including an Account of Robert Livingston of Albany, "the Nephew," a Settler in the Same Province, and His Principal Descendants. New York: Knickerbocker Press, 1910.

Lovejoy, David S. The Glorious Revolution in America: with a New Introduction. Hanover, NH: Wesleyan Univ. Press, 1987.

Lustig, Mary Lou. Robert Hunter, 1666-1734, New York's Augustan Statesman. Syracuse, NY: Syracuse University Press, 1983.

Lustig, Mary Lou. The Imperial Executive in America: Sir Edmund Andros, 16371714. Madison [N.J.: Fairleigh Dickinson University Press, 2002.

Matson, Cathy D. Merchants \& Empire: Trading in Colonial New York. Baltimore: Johns Hopkins University Press, 1998.

Mays, Dorothy A. Women in Early America: Struggle, Survival, and Freedom in a New World. Santa Barbara, CA: ABC-CLIO, 2004.

McManus, Edgar J. A History of Negro Slavery in New York. Syracuse, NY: Syracuse University Press, 1966.

Middleton, Simon. From Privileges to Rights: Work and Politics in Colonial New York City. Philadelphia: University of Pennsylvania Press, 2006. 
Nissenson, Samuel George. The Patroon's Domain. New York: Columbia University Press, 1937.

Norton, Mary Beth. "The Evolution of White Women's Experience." The American Historical Review 89, no. 3 (June 1984).

Otterness, Philip. Becoming German: the 1709 Palatine Migration to New York. Ithaca: Cornell University Press, 2004.

Paddock, William Henry. History of the Police Service of Albany, from 1609 to 1902, from Ancient and Modern Authoritative Records, Illustrating and Describing the Economy, Equipment and Effectiveness of the Police Department of To-day, with Reminiscences of the Past, Biographies and Accounts of Leading Criminal Cases and Trials;. Albany: Police Beneficiary Association of Albany, N.Y., 1902.

Palmer, Archie Emerson. The New York Public School; Being a History of Free Education in the City of New York, . New York: Edwin C. Hill Company, 1908.

Panschar, William G. Baking in America. Evanston, IL: Northwestern University Press, 1956.

Proceedings of the New York State Historical Association. New York: New York State Historical Association, 1904.

Rawley, James A., and Stephen D. Behrendt. The Transatlantic Slave Trade: a History. Lincoln, Neb.: University of Nebraska Press, 2009 Revised Edition.

Reich, Jerome R. Leisler's Rebellion, a Study of Democracy in New York, 16641720, by Jerome R. Reich. Chicago: University of Chicago Press, 1953.

Reid, John G. The "conquest" of Acadia, 1710: Imperial, Colonial, and Aboriginal Constructions. Toronto: University of Toronto Press, 2004.

Ritchie, Robert C. Captain Kidd and the War against the Pirates. Cambridge, MA: Harvard University Press, 1986.

Ritchie, Robert C. The Duke's Province: a Study of New York Politics and Society, 1664-1691. Chapel Hill: University of North Carolina Press, 1977.

Roberts, Benjamin. Through the Keyhole: Dutch Childrearing Practices in the 17th and 18th Century: Three Urban Elite Families. Netherlands: Veloren, 
1998.

Rosen, Deborah A. "Women and Property Across Colonial America: A Comparison of Legal Systems in New Mexico and New York." The William and Mary Quarterly 60, no. 2 (2003): 355-81.

Schama, Simon. The Embarrassment of Riches: an Interpretation of Dutch Culture in the Golden Age. New York: Knopf, 1987.

Schuyler, George Washington. Colonial New York; Philip Schuyler and His Family. New York: Charles Scribner's Sons, 1885.

Shattuck, Martha. A Civil Society: Court and Community in Beverwijck, New Netherland, 1652-54. Diss., Boston University, 1993.

Shattuck, Martha Dickinson. Explorers, Fortunes \& Love Letters: a Window on New Netherland. Albany, NY: New Netherland Institute, 2009.

Shorto, Russell. The Island at the Center of the World. New York: Vintage Books, 2005.

Singer, Roberta R. "The Livingstons as Slave Owners: The "Peculiar Institution" of Livingston Manor and Clermont." In The Livingston Legacy: Three Centuries of American History. New York: Bard College Office of Publications, 1987.

Singleton, Esther. Dutch New York. New York: Dodd, Mead and Company, 1898.

Singleton, Esther. Social New York under the Georges. New York: D. Appleton and Company, 1902.

Smith, Bonnie G., ed. Women's History in Global Perspective. Vol. II. American Historical Association, 2005.

Steen, Herman. Flour Milling in America. Westport: Greenwood Press, 1963.

Stone, Lawrence (Historiker). The Family, Sex and Marriage in England: 15001800. New York: Harper \& Row, 1977.

Taylor, Alan, and Eric Foner. American Colonies: the Settling of North America. New York: Penguin Group, 2001.

Trelease, Allen W. Indian Affairs in Colonial New York: the Seventeenth Century. Ithaca, NY: Cornell University Press, 1960. 
Tuckerman, Bayard. Life of General Philip Schuyler, 1733-1804, by Bayard Tuckerman. New York: Dodd, Mead and, 1903.

Ulrich, Laurel. Good Wives: Image and Reality in the Lives of Women in Northern England, 1650-1750. New York: Oxford University Press, 1983.

Volo, James M., and Dorothy Denneen Volo. Family Life in 17th- and 18thcentury America. Westport, CT: Greenwood Press, 2006.

Voorhees, David William. "The "fervent Zeale" of Jacob Leisler." The William and Mary Quarterly, Third, 51, no. 3 (July 1994): 447-72.

Waite, Diana S., Gary David. Gold, Mark McCarty, and Matthew Bender, eds. Albany Architecture: a Guide to the City. Albany, NY: Mount Ida Press, Published in Association with the Preservation League of New York State, 1993.

Wallace, W. Stewart, ed. The Encylopedia of Canada. Vol. VI. Toronto: University Associates of Canada, 1948.

Wallace, W. Stewart. The Encyclopedia of Canada: General Editor W. Stewart Wallace. Vol. VI. Toronto: University Associates of Canada, 1948.

Waller, George M. Samuel Vetch, Colonial Enterpriser. Chapel Hill: Published for the Institute of Early American History and Culture at Williamsburg, Va. by University of North Carolina Press, 1960.

Wilcoxen, Charlotte. Dutch Trade and Ceramics in America in the Seventeenth Century. Albany, NY: Albany Institute of History and Art, 1987.

Wilcoxen, Charlotte. Seventeenth Century Albany: a Dutch Profile. Albany, NY: Education Dept., Albany Institute of History and Art, 1984.

Wiles, Richard C., and Andrea K. Zimmermann. The Livingston Legacy: Three Centuries of American History. [New York]: Bard College Office of Publications, 1987.

Yalom, Marilyn. A History of the Breast. New York: Ballantine Books, 1998.

Zabin, Serena R. Dangerous Economies: Status and Commerce in Imperial New York. Philadelphia: University of Pennsylvania Press, 2009.

Zimmerman, Jean. The Women of the House: How a Colonial She-merchant Built a Mansion, A Fortune, and a Dynasty. New York: Houghton Mifflin 
Harcourt, 2006.

John H. Virginia University Libraries,

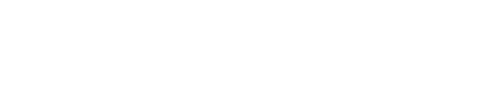

